\title{
The Warnie Volcanic Province: Jurassic Intraplate Volcanism in Central Australia
}

\author{
Jonathon P.A. Hardman', Simon P. Holford ${ }^{2}$, Nick Schofield', Mark Bunch² Daniel Gibbins ${ }^{3}$ \\ 'Department of Geology and Petroleum Geology, University of Aberdeen, Aberdeen, AB24 3FX, UK \\ ${ }^{2}$ Australian School of Petroleum, University of Adelaide, Adelaide, SA 5005, Australia \\ ${ }^{3}$ Vintage Energy, 58 King William Road, Goodwood SA 5034, Australia
}

\begin{abstract}
The Cooper and Eromanga Basins of South Australia and Queensland are the largest onshore hydrocarbon producing region in Australia. Igneous rocks have been documented infrequently within end of well reports over the past 34 years, with a late Triassic to Jurassic age determined from well data. However, the areal extent and nature of these basaltic rocks were largely unclear. Here, we integrate seismic, well, gravity, and magnetic data to clarify the extent and character of igneous rocks preserved within Eromanga Basin stratigraphy overlying the Nappamerri Trough of the Cooper Basin. We recognise mafic monogenetic volcanoes that extend into tabular basalt lava flows, igneous intrusions and, more locally, hydrothermally altered compound lava flows. The volcanic province covers $\sim 7500 \mathrm{~km}^{2}$ and is proposed to have been active between 180-160 Ma. We term this Jurassic volcanic province the Warnie Volcanic Province (WVP) after the Warnie East I exploration well, drilled in 1985. The distribution of extrusive and intrusive igneous rocks is primarily controlled by basement structure, with extrusive and intrusive igneous rocks elongate in a NW-SE direction. Finally, we detail how the WVP fits into the record of Jurassic volcanism in eastern Australia. The WVP is interpreted as a product of extension and intraplate convective upwelling above the subducting Pacific Slab. The discovery of the WVP raises the possibility of other, yet unidentified, volcanic provinces worldwide.
\end{abstract}

\section{Keywords}

Intraplate; volcanism; monogenetic; Australia; Jurassic

\section{Introduction}

Igneous rocks are frequently recognised within sedimentary basins globally, within which their chronostratigraphic record can provide insights into the tectonic evolution of a region (Jerram \& Widdowson, 2005). Although extensive reworked volcaniclastic deposits are documented throughout Central Australia during the Mesozoic (Boult et al., 1998; Barham et al., 2016; Wainman et al., 2019), synchronous volcanic activity is infrequently documented within the sedimentary basins of Central Australia (Allen, 1998). The Cooper and the overlying Eromanga Basin extend for $130,000 \mathrm{~km}^{2}$ and $1,000,000 \mathrm{~km}^{2}$ respectively across 
central, north and eastern Australia. Together, they represent the largest conventional onshore hydrocarbon-producing region in Australia (Hall et al., 2016). The first gas discovery was made in 1963 and since then, over 1,400 producing wells have been drilled, with 190 gas and II5 oil fields discovered throughout both basins (Fig. I) (Mackie, 2015). The majority of discoveries within the Cooper Basin are situated within structural traps on regional highs, however, a number of companies began to pursue unconventional hydrocarbon plays within the basin during the late 2000s, resulting in an increase in activity within the Nappamerri Trough (Hillis et al., 200I; Pitkin et al., 2012; Khair et al., 2013; Scott et al., 2013; Hall et al., 2016). The Nappamerri Trough is the largest and deepest depocentre within the Cooper Basin covering $\sim 10,000 \mathrm{~km}^{2}$ and reaching present day depths of $\sim 4.5 \mathrm{~km}$ (Fig. IA). The acquisition of new well and seismic data due to renewed exploration activity has resulted in the increased recognition of igneous rocks in the Cooper and Eromanga Basins.

Igneous rocks of suspected late Triassic-Jurassic age have been sporadically encountered by drilling during the past 34 years (Short, 1984; Boothby, 1986; Bucknill, 1990; Allen, 1998), though there has been no systematic study of the character, origin and significance of these igneous rocks. Here, we combine extensive seismic, well and airborne geophysical data to document the extent and character of Mesozoic igneous rocks recognised within Eromanga Basin stratigraphy overlying the Nappamerri Trough of Cooper Basin age. The Warnie Volcanic Province (WVP) is the suggested name for this $>7,500 \mathrm{~km}^{2}$ suite of igneous rocks (Fig. IB). The province is named after the Warnie East I exploration well, which was drilled in 1985 and encountered $65 \mathrm{~m}$ of basalt. We provide an in-depth study of the regional implications of the WVP for the Cooper and Eromanga Basins. We find that SE-NW striking intracratonic sag faulting controlled the morphology of igneous rocks whilst the basin structure likely controlled the location of igneous rocks.

Finally, we discuss the origin of the WVP. Evidence for Triassic to mid-Cretaceous volcanic activity is pervasive throughout the sedimentary basins of central Australia, manifested by an influx of volcanic arc-derived sediment into the Eromanga Basin (Boult et al., 1998), silicic tuffs in the Surat Basin (Wainman et al., 2015) and widespread volcanogenic zircons throughout the Great Artesian Basin (Bryan et al., 1997). However, the source of volcanic activity and, furthermore, the origin of intraplate volcanism can be contentious (Conrad et al., 201I; Zhou et al., 2018). We consider the source of the WVP and the tectonic implications for central Australia. We theorise that the WVP's geodynamic origin is 
ultimately linked to subduction at the eastern margin of Gondwana, through asthenospheric shear $\sim 1500 \mathrm{~km}$ from the oceanic trench, however, we also discuss other mechanisms that can produce intraplate volcanism. Our discovery of a previously undescribed volcanic province in an area that has undergone $>50$ years of extensive subsurface data collection due to continued hydrocarbon exploration, raises the prospect of other undiscovered intraplate volcanic provinces both in Australia and in other continental areas worldwide.

\section{Geological Overview of the Cooper and Eromanga Basins}

The geology of southwest Queensland and northeast South Australia, central Australia, is defined by a series of intracratonic basins stacked on top of each other; the Warburton, Cooper, Eromanga and Lake Eyre Basins (Fig. 2 \& Fig. 3).

The Warburton Basin is a lower Palaeozoic sedimentary basin that hosted Silurian to Carboniferous granite emplacement (Murray, 1986; Meixner et al., 2000). The Cooper Basin unconformably overlies the Warburton Basin. The Cooper Basin is a northeast to southwest trending intracratonic structural depression that accommodated the deposition of sedimentary rocks from the late Carboniferous to the Middle Triassic (Gravestock et al., 1998). Several tectonic origins for the Cooper Basin have been suggested, including a mildly compressional structural depression (Apak et al., 1997; Sun, 1997), a depression created through wrenching (Kuang, 1985) and extension during post-compression flexural relaxation (Kulikowski et al., 2015). Deposition throughout the early Permian was dominated by highly sinuous fluvial systems situated on a major floodplain with peat rich swamps and lakes (Khair et al., 2015). Later Triassic deposition took place in a period of tectonic quiescence (Gravestock et al., 1998).

Deposition in the Cooper Basin was terminated by regional uplift, compressional folding and erosion in the middle Triassic. The Cooper Basin is unconformably overlain by the Eromanga Basin, which forms part of the Great Artesian Superbasin, a group of interconnected basins that cover much of Queensland, South Australia and New South Wales. The Eromanga Basin is an intracratonic sag basin whose subsidence has been attributed to dynamic topography induced by subduction of the pacific plate below Australia (Gallagher \& Lambeck, 1989; Russell \& Gurnis, 1994). 


\section{I The Jurassic Succession of the Eromanga Basin}

The Jurassic succession of the Eromanga Basin is of stratigraphic importance as it is where the extrusive igneous rocks documented within this study are believed to be located. Much of the Jurassic strata in the Eromanga Basin consists of predominantly quartzose fluviatile sandstones with subordinate shales and some coals (Burger \& Senior et al., 1979; Exon \& Burger, 198I; Draper 2002). Sediments in the Eromanga Basin can be divided into three packages of decreasing age; lower non-marine, marine and upper non-marine. The focus of this study is the lower non-marine package that was deposited between the early Jurassic $(\sim 200 \mathrm{Ma})$ and the early Cretaceous $(\sim 155 \mathrm{Ma})$, within which the extrusive volcanics of the WVP are recognised (Fig. 2). During this time, large sand-dominated, braided fluvial systems drained into lowland lakes and swamps. Throughout deposition, it is believed that sediment supply was a competing product of input from arc volcanism to the east, and sediment sourced from stable cratonic regions to the south (Boult et al., 1997). In the next part of this paper we briefly detail the Early to Late Jurassic stratigraphy in order to provide a palaeogeographic framework for the study. The stratigraphic framework of the Jurassic succession has been iterated on considerably in the last 20 years, evidenced by the progression of Alexander \& Hibburt's stratigraphic ages (1996) to Reid et al.'s (2009), to those listed on the Australian Stratigraphic Units Database.

\section{I.I Poolowanna Formation, Early Jurassic, $200-178 \mathrm{Ma}$}

In southwest Queensland, the Poolowanna Fm. sits unconformably on top of the Late Triassic unconformity, which formed as a result of uplifting, tilting, and erosion of the Cooper Basin at the end of the Early to Middle Triassic (Fig. 2). Lithologies consist of coal and silt deposited in a highly sinuous fluvial setting with minor coal swamps (Hall et al., 2016).

\section{I.2 Hutton Sandstone, Early to Middle Jurassic, I 78-I 66 Ma}

The Hutton Sandstone is a high energy braided fluvial Jurassic sandstone that either sits conformably on top of the Poolowanna Fm. or, where the Poolowanna is not present, unconformably above Triassic sediments (Kapel, 1966; Watts, 1987). 


\section{I.3 Birkhead Formation, Middle to Upper Jurassic, 166-160 Ma}

124 The boundary between the Hutton and Birkhead formations is sharp to transitional across the Eromanga Basin (Lanzilli, 1999) and is associated with a change in the depositional setting from the high energy, braided fluvial setting of the Hutton Sandstone to a low energy, fluvial-deltaic to lacustrine setting in the Birkhead Formation (Watts, 1987; Lanzilli, 1999). This decrease in depositional energy is also associated with a change in sediment provenance from craton-derived sediment to lithic-rich, volcanogenic sediment from a proposed volcanic arc situated to the east above the subducting Pacific plate (Lanzilli, 1999).

The diachronous influx of volcanogenic sediments can be traced across the Eromanga Basin (Boult et al., 1997). There are several key features associated with the sediments shed from the volcanic arc (Paton, 1986):

- $50 \%$ quartz with high amounts of potassium and plagioclase feldspar. Trace amounts of tourmaline, pyroxene, mica and zircon are also present (Watts, 1987).

- Common altering of the above lithics to kaolinite and chlorite or replacement of carbonate cements such as siderite or dolomite.

- Rare glassy fragments.

Based on the lithology of the volcanogenic sediments, it has been concluded that the volcanics that formed them were of acid to intermediate affinity (Paton, 1986).

\section{I.4 Adori Sandstone, Upper Jurassic, 160-155 Ma}

The Birkhead Formation is capped by the Adori Sandstone, marked by a transition to clean, non-volcanogenic sedimentation. The Adori Sandstone is a well sorted and typically cross bedded, fine to coarse-grained sandstone deposited in a low sinuosity fluvial system consisting of channel, point bar and flood plain deposits in the Central Eromanga Basin (Burger \& Senior, 1979; Alexander \& Hibburt, 1996).

\subsection{Structural Setting of the Study Area}

Structurally, the Cooper Basin can be divided into southern and northern sections (Gravestock et al., 1998; Hall et al., 2016). To the north, depocentres are dominantly Triassic, with Permian depocentres in the south (Hall et al., 2018). The northern and southern sections of the Cooper Basin are separated by the Jackson-Naccowlah-Pepita Trend (JNP trend) (Fig. I). In the south west, depocentres are generally thicker, reaching a 
maximum thickness of $2400 \mathrm{~m}$ in the Nappamerri Trough (Hall et al., 2016) and many of these depocentres have experienced synclinal folding due to differential compaction (Apak et al., 1997). The major depocentres are separated by northeast-southwest trending ridges (Gravestock et al., 1998).

157 The area of focus in this study is the eastern Nappamerri Trough of north east South 158 Australia and south west Queensland. The Nappamerri Trough contains the deepest 159 basement within the Cooper Basin and hosts the Halifax well that intersected the deepest Permian-age sedimentary rocks in the basin at $4,209 \mathrm{~m}$. To the north, the Nappamerri Trough is bounded by the Gidgealpa, Canway, Packsaddle and Innamincka ridges (Fig. IA). The southern extent of the Nappamerri Trough is bounded by the Della-Nappacoongee, Dunoon and Murteree ridges (Fig. I) (Hall et al., 20I6).

\section{Methodology}

\section{I Identification of Volcanics Using Subsurface Data}

Here we describe the main techniques that were used to investigate igneous rocks within the Nappamerri Trough.

\section{I.I Seismic Data}

Seismic reflection data has been shown by numerous studies to be especially effective at imaging igneous rocks due to the high acoustic impedance of igneous material when compared to surrounding sedimentary rocks and the distinctive morphology of lava flows and intrusions (Planke et al., 2000). Here we provide a brief introduction to the different types of igneous rock identified in the subsurface on seismic reflection data.

Vents identified within seismic reflection data are typically grouped into either hydrothermal or volcanic vents (Reynolds et al., 2017). The morphologies of hydrothermal vents and volcanoes are similar as they both exhibit eye, dome or crater shaped morphologies in seismic data (Fig. 4)(Planke et al., 2005; Reynolds et al., 2017). This can make distinguishing hydrothermal vents from volcanoes difficult when seismic reflection data are the sole data source.

Volcanoes can be confidently identified using seismic reflection data where they extend into lava flows (e.g. Fig. 4A-D). Lava flows are distinguishable as layer-parallel acoustically hard, 
bright reflectors within the subsurface (Planke et al., 2000; Schofield \& Jolley, 2013; Hardman et al., 2019) (Fig. 4B). Extrusive igneous rocks are distinguishable from intrusive igneous rocks as they do not transgress stratigraphy.

Igneous intrusions have been studied intensely using 3D seismic data (Bell \& Butcher, 2002; Thomson \& Schofield, 2008; Archer et al., 2005; Magee et al., 20I4). Igneous intrusions form acoustically hard, bright reflectors that are layer parallel or transect stratigraphy. In places, they can produce forced folding of the overburden with onlapping stratigraphy facilitating age-dating of the intrusion (Trude et al., 2003).

\section{I.2 Seismic Attributes}

3D seismic reflection data facilitates the analysis of the geophysical properties of igneous rocks in 3D. Seismic attributes such as RMS amplitude and spectral decomposition have proven to be effective tools in picking the extent and morphology of lava flows in seismic data (Figs. 4C \& G) (Schofield \& Jolley, 2013; Planke et al., 2017; Hardman et al., 2019). Spectral decomposition involves filtering 3D seismic reflection wavelets to produce three amplitude components at distinct frequencies that are displayed as separate colour channels using the primary colours red, green and blue. These channels are then blended to produce full colour spectrum images where the igneous rocks appear visibly different to the surrounding sediments, due to their differing reflectiveness for particular frequencies (they transmit acoustic energy efficiently at all frequencies). Furthermore, this technique can be used to investigate the geometries of igneous rocks and features such as inflation lobes can help with distinguishing igneous intrusions from extrusive igneous rocks.

\section{I.3 Well Data}

In addition to the use of seismic data, the integrated analysis of borehole data including wireline log responses, core and cuttings is essential in accurately identifying igneous rocks within the subsurface (Nelson et al., 2009; Rider \& Kennedy, 20I I; Watson et al., 2017). The onshore response of igneous rocks in outcrop has been linked to offshore observations facilitating the identification of different volcanic facies through petrophysical and petrological analysis (Nelson et al., 2009; Millet et al., 2016).

210 Here, we use a combination of petrophysical and petrological data in our description of the 211 WVP. Although cuttings and core were not examined within this study, descriptions were 212 available within well reports that were integrated with petrophysical data and seismic 
213 reflection data to provide a comprehensive overview of the data available. It is important to recognise that the petrological descriptions taken from well reports is secondary information and, as such, variable in quality. Wherever petrological descriptions have been taken from end of well reports it is explicitly stated within the text with a reference to the relevant well report.

\subsection{Description of Dataset}

219 The Cooper and Eromanga Basins have been explored extensively over the past 60 years 220 and are characterised by the largest collection of well and seismic reflection data for any onshore sedimentary basin in Australia. Over 2000 wells have been drilled in the Cooper and Eromanga Basins. Despite this, of the wells available, only 3 (Lambda I, Orientos 2 and Kappa I) were identified as having intersected extrusive volcanic rocks with only I well (Warnie East I) encountering an intrusive igneous rock. To estimate the relative age of the volcanic units, well data were tied, where possible, to the seismic reflection surveys available. For constraining the age of the Eromanga succession within the Central Nappamerri trough, the Halifax, Etty, Padme, Charal and Anakin wells represented key datasets (location on Fig. IC).

A large database of seismic reflection data was available through Santos Limited and the Queensland Government's Department of Natural Resources and Mines. 3D and 2D seismic reflection surveys throughout the South Australian and Queensland sides of the basin were assessed for the presence of igneous rocks (the extent of the seismic data examined is visible on Fig. IB). Notably, only four surveys available to this study (the Winnie 3D, the Gallus 2D, the Madigan 3D and the Snowball 3D survey (provided for use by Santos Limited)), were interpreted to contain igneous rocks and a summary of these surveys is provided in Table I. Furthermore, 3 individual 2D seismic lines were available across the Lambda I, Orientos 2 and Warnie East I wells. Seismic data were displayed using normal (American) polarity, whereby a downward increase in acoustic impedance corresponds to a positive (blue) reflection and a downward decrease a negative (red) reflection. The only exception to this is the Snowball 3D survey that was displayed such that a downward increase in acoustic impedance corresponds to a red, negative reflection (European polarity). Within the Jurassic succession the average dominant frequency within the seismic data was $\sim 40 \mathrm{~Hz}$, with volcanic rocks in the region having an acoustic velocity of 4 to $6 \mathrm{kms}^{-}$ 
244 ' (taken from the Lambda I exploration well). Using an average velocity of $5 \mathrm{kms}^{-1}$ a vertical resolution of $\sim 30 \mathrm{~m}$ and a detection limit of $4 \mathrm{~m}$ was calculated.

Here we present an overview of all the available datasets that constrain the distribution and age of igneous rocks within the study area. We recognise three distinct types of igneous rocks within this study:

- Extrusive igneous rocks

- Intrusive igneous rocks

- Altered extrusive igneous rocks

252 Each type is described in detail using the available well and seismic data before the regional character of the Warnie Volcanic Province as a whole is discussed using regional gravity and magnetic surveys. It is important we recognise that whilst this is the extent of the data that was available during this study, the authors are aware of other seismic reflection surveys within the Nappamerri Trough that were not available to download digitally and were not possible to acquire within the period of time during which this study was conducted. These surveys may also image igneous rocks that could fuel further work on the area.

\section{Description of Extrusive Igneous Rocks}

\section{I Well Data}

261 Unaltered, basaltic, extrusive igneous rocks are recognised in the Lambda I and Orientos 2 wells in the eastern Nappamerri Trough.

The Lambda I well was drilled in 1984 by Delhi Petroleum Pty. Ltd. At a depth of I570.9 m, $283 \mathrm{~m}$ igneous rocks were intersected, directly underlying the base of the Birkhead Fm. (Fig. 12). The upper $33 \mathrm{~m}$ of basalt are noted as heavily weathered, fractured and vesicular in the Lambda I well report (Short, 1984). The remaining $250 \mathrm{~m}$ of basalt is described as fresh and crystalline. It has low gamma ray values, with consistently high density and acoustic velocity (Fig. 12A). There are localised areas where the density drops drastically, however, these are associated with increases in the caliper and may therefore point to caving of the wellbore when it was drilled or fractures within the basalt, rather than lithological variations. At the base of the basalt $\sim 1.5 \mathrm{~m}$ of core was cut, within which the fine grained, crystalline nature of the basalt is apparent (Fig. 5A, see picture). 
273 Similarly to Lambda I, Orientos 2 drilled through igneous rocks situated at $1555 \mathrm{~m}$, beneath the Jurassic age Adori Sandstone (Fig. 14). The well drilled through $34 \mathrm{~m}$ of igneous rocks before drilling was ceased, prior to the well reaching the base of the igneous rocks. The igneous rocks are described as dark green, grey black with quartz inclusions and common amphiboles in the end of well report (Bucknill, 1990). Similar to the Lambda I well, Orientos 2 encountered a $14 \mathrm{~m}$ section of weathered basalt identifiable by low density and sonic values in the well logs, followed by a high density and high velocity section, matching the petrophysical response of the Lambda I igneous rocks. Draper (2002) noted that Orientos 2 was drilled $<1 \mathrm{~km}$ from Orientos I, which did not intersect basalt, suggesting that the basalt In Orientos 2 might be intrusive in origin. However, we note that Orientos I may have been drilled beyond the limit of the basalt and, as such, we do not take the absence of igneous rocks in Orientos I to be indicative of an intrusive origin for the Orientos 2 igneous rocks.

Nelson et al. (2009) provided compelling evidence for the use of binning velocity data in estimating the type of volcanic rock present. In order to investigate the extrusive or intrusive nature of the Lambda I igneous rocks, interval velocity histograms were created. They were then binned with a bin spacing of $0.125 \mathrm{~m}$ order to create a velocity histogram (Fig. I2C). These were superimposed on the velocity histogram fields of Nelson et al., (2009) that were obtained from boreholes on the Faroe Islands in the North Atlantic, in order to compare the acoustic velocities of igneous rocks in the Nappamerri Trough with values from extrusive igneous rocks in the Northwest Atlantic. It can be seen in Fig. $5 \mathrm{C}$ that the Lambda I volcanics show a very strong similarity to the tabular basalt analysed by Nelson et al. (2009).

Additionally, vitrinite reflectance data (Boothby, 1986) was recorded for sediments deposited on top of the Lambda-I volcanics (Fig. 5B). Notably, in the sediment contact with the volcanics, there is no deviation towards high \%RoMax, suggesting that the Lambda I volcanics had little thermal effect on the overlying organic matter. It has been observed in locations such as Namibia that the thermal effect of lava flows is restricted to $\ll<1 \mathrm{~m}$ depth below lava contacts (Grove et al., 2017) whereas igneous intrusions have a much larger thermal effect on surrounding sediments due to their inability to release heat directly to the earth's surface (see Utgard Sill Complex, Aarnes et al., 2015). If this were an intrusion, it is expected that the VR values would be elevated (Stewart et al., 2005), and the absence of such elevated values implies that the basalt is extrusive. 


\subsection{Seismic Data}

Extrusive igneous rocks have been documented using the available seismic data. These observations will focus on the Winnie 3D survey as it is the largest, highest quality 3D dataset within which the full range of igneous rocks is observed. From there, we build out to the other seismic surveys utilised.

311 In a single 2D seismic line intersecting the Lambda I well the tabular basalt intersected by the well corresponds to a high amplitude reflection most pronounced at the location of the well but also continuing $\sim 3 \mathrm{~km}$ to the west of the survey (Fig. 6). The centre of the survey (and the location of the well) corresponds with a $\sim 1.5 \mathrm{~km}$ wide anticline that exhibits doming on the order of $\sim 150$ ms. Below the anticline and the location of the volcanics, the 2D seismic reflections are visibly distorted, being most pronounced beneath the location of the well where a velocity pull-up effect is visible.

Within the Winnie 3D survey, we identified $\sim 100,<=4 \mathrm{~km}^{2}$ cone shaped features that often express an eye-shaped morphology, doming and velocity pull-up effects similar to those observed in the location of the Lambda I well (Fig. 4B). The cones within the survey are less than $2 \mathrm{~km}$ long and $750 \mathrm{~m}$ wide, and often elongate in a NW-SE direction (Fig. 6). Due to the extrusive nature of the Lambda I well, their stratigraphic concordance and their cone shaped morphology in seismic, we have interpreted these as monogenetic volcanoes, small cumulative volume volcanic edifices built up by one continuous, or many discontinuous, small eruptions over a short time scale $(<=10$ years) (Németh \& Kereszturi, 20I5).

In the Winnie 3D survey, twelve of the volcanoes are linked with what appear to be elongate, NW-SE oriented lava flows that are conformable to stratigraphy and have dimensions of 2-7 km in length and 0.5-2.5 km in width (covering areas of 4-13.5 km²) (e.g. Figs. 7 \& 8).

The northwards continuation of the monogenetic volcanoes and lava flows that were detailed in the Winnie 3D survey is imaged within the Gallus 2D survey (Fig. IIA-C). To better constrain the distribution of the volcanics in the Gallus 2D survey, the top and bottom of the igneous rocks were mapped. From these, we calculated the isochron thickness of the igneous rocks in the area (Fig. 9A). Like the Winnie 3D survey, volcanism was more pervasive towards the east, with the thickest volcanics ( $\sim 300 \mathrm{~ms}$, approximately 
$163 \mathrm{~m}$ ) located at the eastern edge of the survey. The northernmost extent of the Warnie Volcanic Province is recognised in the Madigan 3D survey where two monogenetic vents were identified within the seismic data. Although, neither vent was penetrated by a well and no surface flows were mapped away from the vents, it seems likely that they are volcanic in origin due to their similarity with the other volcanoes in the Nappamerri Trough.

We have also interpreted one feature within the Warnie Volcanic Province as a diatreme. Maar-diatreme volcanism can occur where a volcanic pipe forms through gaseous explosions that cut into the country rock (Fig. $4 \mathrm{E}-\mathrm{H}$ ) (White \& Ross, 20II). These explosions form a maar (the crater and associated ejecta ring) and a diatreme (the root to the maar), consisting of a steep-sided cone shaped structure filled with pyroclastic, volcanic and country rocks) (White \& Ross, 20II). Unlike vents and associated lava flows, they consist of downward dipping reflectors that truncate the underlying stratigraphy with typically chaotic internal reflectors (Fig. 4F). Spectral decomposition proved to be the most powerful tool for identifying maar-diatremes above the Nappamerri Trough, as the circular crater morphology stood out against the surrounding sediments (Fig. 4G). One feature interpreted to be a diatreme was identified within the survey, displayed in detail in (Fig. 4). It is $\sim 2.25 \mathrm{~km}^{2}$ and $\sim 120 \mathrm{~m}$ deep (I50 ms, TWT) and is found in the west of the Winnie 3D survey (see Fig. 6).

\section{Description of Intrusive Igneous Rocks}

\section{I Well Data}

Igneous rocks intersected within the Warnie East I well are lithologically unique amongst the igneous rocks penetrated by wells in the WVP. Located at $2103 \mathrm{~m}$ depth within the Permian Toolachee Fm (Fig. 10), the 65 m thick basalt is described in the end of well report as fine grained and dominated by plagioclase laths intergrown with augite (Boothby, 1986). The upper $12 \mathrm{~m}$ of the volcanics are described as altered and calcareous, containing phenocrysts of augite with minor pale green talc and minor calcite veining.

Vitrinite reflectance data was acquired within the Warnie East I well. (Fig. IOB). Samples of vitrain were obtained and mean maximum reflectance of vitrinite calculated (Smith, 1987). 
367 Vitrinite reflectance samples adjacent (directly above and below) to the basalt show a marked increase to $4.5 \%$ relative to surrounding Toolachee sediments that are typically I.5I.75\%. Whereas extrusive volcanics appear to have little thermal effect on the surrounding sediments (e.g. Grove et al., 2017), igneous intrusions typically show uniform heating on either side of the volcanics, as is observed here (Aarnes et al., 2015). Coupled with its stratigraphic position within the Permian Toolachee Fm., where no other volcanics have been documented within the Cooper Basin, we suggest that Warnie East I contains the sole identified well intersection of an igneous intrusion in the WVP.

\subsection{Seismic Data}

376 Intrusive igneous rocks are also identified within the seismic data available. A 2D seismic 377 reflection line was available that runs across the location of the Warnie East I well (Fig. II). 378 Unlike the Lambda I and Orientos 2 volcanics, the igneous rocks within the Warnie East I well sit within the Toolachee Fm., a highly reflective sequence of heterogeneous lithologies consisting of sandstones, siltstones and coals. As such, the igneous rocks are difficult to distinguish on seismic reflection survey data, although a shallow saucer-shaped reflection intersects the well path of the Warnie East I well at the depth that igneous rocks are located. The reflection is $\sim 1.5 \mathrm{~km}$ wide and transects the Toolachee Fm. over a depth range of $50 \mathrm{~ms}$. The shallow saucer shape that the reflection event exhibits is common among igneous intrusions within sedimentary basins, corroborating with the well data that suggests the igneous rocks are intrusive in nature.

Igneous intrusions within the Winnie 3D survey are identified as igneous rocks that cross-cut the Triassic to Jurassic strata; notably the Nappamerri, Hutton and Birkhead Fms (e.g. Fig. 12). We identified and mapped I4 intrusions in the seismic data; these occur $\sim 100$ $200 \mathrm{~ms}(\sim 105-210 \mathrm{~m})$ below the palaeosurface. Most of the sills identified are of a similar scale to the lava flows in the area $(2-4.5 \mathrm{~km}$ long, $1.2-1.7 \mathrm{~km}$ wide).

The Winnie 3D survey also hosts a spectacular single intrusion, $14 \mathrm{~km}$ long and 8 $\mathrm{km}$ wide, by far the largest igneous feature in the WVP (Fig. 12). Classical intrusion-related features such as inflation lobes are observed within spectral decomposition (Fig. 12C). Around 20 vents cross-cut this intrusion (see pockmarks on Fig. 12C), in places leading to extrusive lava flows in the overlying sediments (see surface flows on Top Birkhead overlying the intrusion in Fig. 12B). The presence of the pockmarks on the surface of the intrusion 
suggest emplacement of the sill predated a later stage of volcanism that occurred towards the top of the Birkhead Fm.

\section{Description of Altered Igneous Rocks}

This study has so far dealt with igneous rocks of a very consistent lithology preserved within or above the Central Nappamerri Trough. However, the Kappa I well and Snowball 3D seismic reflection survey, located on the very southern edge of the mapped extent of the WVP, preserve igneous rocks of a very different character (Figs. 13-15).

\section{I Well Data}

The Kappa I well was drilled in 1997 on behalf of Santos Limited with the aim of evaluating hydrocarbon presence within the Toolachee, Patchawarra and Epsilon formations (Allen, 1998). Kappa I is located above a large anticline and is the southernmost of a string of prospects located above the northeast Della-Nappacoongee Ridge, which deepens northwards into the Nappamerri Trough (Fig. I). Between 1895 and $2115 \mathrm{~m}$, the Kappa well intersected a $120 \mathrm{~m}$ thick succession of igneous rocks below a thinned $21 \mathrm{~m}$ succession of Hutton Sandstone (Fig. I3). Within the well report, the igneous rocks are ascribed a late Permian to Middle Triassic age (Allen, 1998).

Although core description or in-depth petrological work was not undertaken during this study, rock chips and cuttings of the igneous rocks are described extensively within the Kappa I end of well report (Allen, 1998). Due to the large amount of alteration, the volcanics are described as a chloritized basalt with abundant plagioclase, chlorite, carbonates and quartz. However, the well report distinguishes two types of igneous rocks. Firstly, a vesicular microporphyritic basalt was described that consists of olivine and pyroxene phenocrysts contained within a fine grained or glassy groundmass. Secondly, a less abundant coarse-grained holocrystalline basalt that is composed of randomly oriented plagioclase laths, ferromagnesian crystals and accessory magnetite plus ilmenite. Importantly, and pervasively throughout the succession, a fibrous chlorite is described as having replaced much of the ferromagnesian minerals and groundmass as well rimming and filling vesicles within the basalt.

The Igneous succession in Kappa I also has an unusual petrophysical expression. In our interpretation, we have divided the volcanics into two facies based on the above description; 
a volcaniclastic breccia and in-situ basalt (Fig. 13). The in-situ basalt (e.g. the section between $1900 \mathrm{~m}$ and $1960 \mathrm{~m}$ (Fig. 13)) has a 'saw-tooth' response with a relatively low gamma response of $\sim 40$ api. Acoustic velocities from the sonic velocity log $\left(\sim 4 \mathrm{kms}^{-1}\right)$ are consistently lower than those observed in the Lambda I and Orientos 2 wells $\left(\sim 5.5-6 \mathrm{kms}^{-}\right.$ '). The chaotic, saw-tooth response is indicative of the highly altered nature of the volcanic succession in Kappa I and can be diagnostic of compound lava flows (Millet et al., 2016; Hardman et al., 2019) (Fig. 18). The resistivity throughout the section consistently measures I5 $\Omega \mathrm{m}$. As with the Lambda I well, we constructed a velocity histogram for the igneous rocks in the Kappa I well. When compared to Nelson et al.'s velocity histograms (2009) the best match was with that of Compound-braided flows (Fig. I3B). However, the upper half of Nelson et al.'s (2009) histogram is missing in the Kappa I volcanics, suggesting that the more crystalline, high velocity material is either absent or has been altered to lower velocity material.

442 The volcaniclastic breccia is described as consisting of poorly sorted, subangular, volcaniclastic igneous rock of very fine sand to granule size (Allen, 1998). The log response for the volcaniclastic breccia is characterised by a jagged petrophysical response when compared to the in-situ basalt. Although the gamma ray values ( 40 api) are similar to those of the in-situ basalt, the acoustic velocities (between 2800 and $4 \mathrm{kms}^{-1}$ ) are consistently lower. Furthermore, the volcaniclastic breccia is water saturated with a resistivity of $2-3$ $\Omega m$, although this may also reflect the magnetite and ilmenite within the basalt. Finally, below $2050 \mathrm{~m}$ to the base of the volcanic succession, the caliper tool widened significantly suggesting that the volcaniclastics in this part of the succession are considerably unconsolidated and/or fractured.

\subsection{Seismic Data}

The top of the Kappa I volcanics is interpreted to correlate with a bright, laterally continuous reflection that was present across the whole of the Snowball 3D survey (Figs. I4 \& 15). Above the top Kappa I volcanics a second reflector, deemed here the 'Top Volcanic Mounds,' was mapped in parts of the Snowball 3D survey adjacent to a series of mound-like structures, appearing in places to downlap onto the top Kappa I volcanics (Fig. I5). The centres of these-mound shaped structures are marked by a notable brightening of the reflectors and they are underlain by vertical vents similar to those seen in the other surveys. We thus interpret these mound structures to be a series of volcanic edifices. 
461 The volcanics present in the Snowball 3D survey are notably different to those preserved in the Nappamerri Trough (e.g. Fig 7-9). Rather than isolated, monogenetic vents or flows, they are interpreted to represent a thick package (up to $~ 150 \mathrm{~ms}$ ) of mixed volcanics and volcaniclastic breccias (based on evidence from Kappa I) that thin towards the southwest of the survey (Fig. 15A) (i.e. the southern edge of the Nappamerri Trough). Although the true extent of them is not imaged within the survey (they are interpreted to extend beyond the survey limits to the northeast), laterally they extend over $6 \mathrm{~km}$.

\section{Geophysical Surveys of the Nappamerri Trough}

Alongside seismic and well data, airborne geophysical surveys were examined in order to further delineate the regional distribution of the WVP (Fig. 2IA). A gravity data grid was downloaded from the Queensland Government's data repository. The grid is a compilation of open file gravity surveys collected by exploration companies and State and Federal regional surveys, compiled in 2014. In southwest Queensland, the Nappamerri Trough is typically characterized by a broad gravity low. However, a pronounced $\sim 50 \times 50$ $\mathrm{km}$ gravity high is apparent in the northeast Nappamerri Trough (Fig. 16A). Furthermore, the quantity of mapped intrusive and extrusive volcanics increases towards the centre of this $50 \times 50 \mathrm{~km}$ gravity anomaly (Fig. IB). This corresponds with an increase in the thickness of igneous rocks mapped within seismic data (see Figs. 2, 7 and 9).

In addition to gravity data, a IVD magnetic intensity survey has been analysed that was also downloaded from the Queensland Government's data repository (Fig. 16B). The first vertical derivate filter enhances the high frequency content in the survey, highlighting magnetic anomalies caused by shallow sources such as igneous rocks that are situated at shallower depths than the base of the Cooper Basin succession. The Nappamerri Trough is generally marked by a low in the magnetic intensity whilst the bounding ridges are magnetic highs. However, within the Nappamerri Trough, many small $\left(<8 \mathrm{~km}^{2}\right)$ circular magnetic anomalies can be observed (Fig. 16B). Basalt is highly susceptible to being magnetised (Tarling, 1966), which has facilitated the recognition of buried volcanic rocks elsewhere in the world (Segawa \& Oshima, 1975). Notably, many of the smaller magnetic anomalies do correspond to the location of igneous rocks in the Winnie 3D survey (Fig. 16C).

When the gravity data is superimposed on top of the magnetic data, there is a clear correlation between the location of igneous rocks interpreted using seismic data, the magnetic anomalies and the gravity high identifiable within the Nappamerri Trough (Fig. 16D 
\& E), suggesting that regional geophysical surveys help to constrain the distribution and location of the WVP and other intraplate volcanic provinces. Perhaps most interesting is that the correlation between circular magnetic anomalies and areas with a strong gravity response can be extended beyond the area of the WVP interpreted during this study (Fig. 16E). To the east and southeast of this study, circular magnetic anomalies appear to be coincident with gravity highs. If these anomalies are proven to be volcanic in nature, the extent of the Warnie Volcanic Province could be greater than the interpreted $7500 \mathrm{~km}^{2}$.

\section{The Age of the Warnie Volcanic Province}

This study has detailed the character and extent of igneous rocks within the Cooper and Eromanga basins which has facilitated a regional overview of the WVP (Fig. 17). Here we synthesise the different methods used to define an age range for the eruption and emplacement of the igneous rocks.

\section{Previous Geochemical Analyses}

K-Ar dating was conducted on both the Lambda I extrusive basalt and the Warnie East I intrusive basalt. In the Lambda I well, K-Ar dating was conducted on a bag of drill cuttings taken from a depth of $1658 \mathrm{~m}$ by Murray (1994). Although the samples are described as being too altered to be used for total rock analysis, fresh plagioclase within the cuttings was separated for analysis and used to determine an age of $227+/-3 \mathrm{Ma}$, suggesting emplacement of the basalt during the early Triassic (Murray, 1994). However, in Lambda-I, the basalt is situated between the Jurassic Birkhead Fm. and the Triassic Nappamerri Gp., supporting a Late Triassic to Jurassic age (Draper, 2002). K-Ar dating of basaltic volcanic rocks is often unreliable (Schofield et al., 2017), due to unquantified argon loss (Kelley, 2002). It is noted within the well report that the loss of argon due to subsequent thermal events or contamination of drill cuttings is not accounted for in the quoted error (Murray, 1994).

Within the Warnie East I well, K-Ar dating was conducted on a sample of drill core from $2163 \mathrm{~m}$ (Murray, 1994). Again, the rock was too altered to be used for whole rock K-Ar analysis and, instead, unaltered pyroxene was used for dating. A middle Cretaceous age of $100 \pm 9 \mathrm{Ma}$ was calculated (Murray, 1994), significantly younger than the rest of the WVP and the Permian host rock within which the intrusion is located. This disparity in the ages determined by K-Ar dating led Draper (2002) to deem the the age dating as 'equivocal.' 
524 Whilst K-Ar dating is considered be relatively unreliable, there are a number of other agedating techniques that could be conducted on cuttings or core from the Warnie Volcanic Province. U-Pb, Re-Os and Ar-Ar could all be analysed to provide independent constraints on the age of the igneous material (Liu et al., 2017). Furthermore, these geochemical measurements can provide insights into the source of these volcanics (Pande et al., 2017) and are an avenue for future work in the area. In the absence of more geochemical data, it is important to consider the K-Ar ages with respect to other data.

\section{Seismic Data}

When tied to the seismic data, the Hutton Sandstone and equivalent sediments (not penetrated by the Lambda I well) are seen to onlap the Lambda I volcanics. The lava flow extending away from Lambda I sits atop Triassic Nappamerri Group sediments of the Cooper Basin whereas the volcanics penetrated by Lambda I appear to cross cut the Triassic stratigraphy.

The timing of igneous activity within the Winnie 3D survey was constrained by the stratigraphic relationship between igneous activity and the Triassic to Jurassic stratigraphy in the study area. In places, intrusions are observed to have caused forced folding of the overburden, as evidenced by onlap of Birkhead Fm. sediments onto the deformed overburden overlying the intrusions (Fig. 12B). Onlap of sedimentary rocks onto these forced folds was used to constrain the age of the intrusion (Trude et al., 2003), whilst the strata-concordant lava flows elsewhere in the survey were assigned an approximate age based on their stratigraphic level. We estimate that volcanism lasted throughout deposition of the Hutton and Birkhead formations between $\sim 178$ and 160 Ma, with the youngest volcanics identified as surface flows emplaced on the top Birkhead marker horizon (Alexander \& Hibburt, 1996).

Similarly, in the Gallus 2D survey whilst none of the volcanics were intersected by any wells, the approximate stratigraphic age was constrained by the nearby Halifax and Etty wells (Fig. 9C), placing the volcanics within the Hutton and Birkhead formations, as found for the Winnie 3D survey.

The Madigan 3D volcanics appear to sit near the top of the Nappamerri Group, however, this would place them in the middle Triassic $\sim 240 \mathrm{Ma}, \sim 60$ Myrs older than the rest of the WVP. An alternative explanation would be the emplacement of these vents at the very base 
555 of the Jurassic in this region (a maximum age of $\sim 200 \mathrm{Ma}$, Fig. 2), as they appear to cross-cut all of the Triassic Nappamerri Group strata. This second explanation is preferable as it would fit with the igneous rocks observed throughout the rest of the WVP.

We conclude that the vast majority of igneous rocks identified using seismic reflection data and well data throughout this study can be constrained to a broad age range between $\sim 180$ and $160 \mathrm{Ma}$, spanning the Middle Jurassic. Further work is encouraged to better define the age of the Warnie Volcanic Province, particularly geochemical analyse that would help constrain both the origin and timing of volcanism.

\section{Discussion}

\section{I The Origin of Altered Volcanics Within the Warnie Volcanic Province}

The nature of the igneous rocks within the Kappa I well and Snowball 3D survey is distinct when compared to the rest of the Warnie Volcanic Province, consisting of a mixed sequence of in-situ basalt and volcaniclastics breccias. What isn't clear, however, is the origin of the volcanics. Within the Kappa-I well report, the sequence is described as pyroclastic in nature (Allen, 1998). Whilst this interpretation can account for some of the altered volcaniclastics, it does not explain the extensive sequence of altered basalt. An alternative explanation may be differing sedimentation and eruption rates within the Eromanga leading to prolonged exposure of volcanic rocks emplaced on the rim of the Nappamerri Trough. However, Mid-Late Jurassic sedimentation rates at Kappa I of 2.4 m.my ${ }^{-1}$ (calculated by dividing the thickness of the Hutton to Adori succession by a duration of 23 Myrs) are not significantly lower than those in the Warnie or Lambda wells (2.8 and $2.5 \mathrm{~m} . \mathrm{my}^{-1}$ respectively). Hence, alteration does not appear to be a consequence of extensive surface exposure.

A more compelling explanation for the Kappa I volcanics is hydrothermal alteration. In volcanic regions, many lakes are typically fed by hot springs. In the East African Rift, discharge of hydrothermal water can produce authigenic chlorite with calcite and quartz forming pore filling cements (Renaut et al., 2002). These minerals, particularly chlorite, are noted extensively within the petrological description of the Kappa I well. Additionally, the Kappa I well lies above the Kinta structural trend which could have provided a pathway for 
585 hydrothermal fluids into the Eromanga succession. Basin-wide hydrothermal fluid circulation has been noted within the Cooper Basin (Middleton et al., 2014, 2015). In the Nappamerri Trough, these fluids are believed to have formed due to rifting of the eastern Australian margin during the mid-Cretaceous (Middleton et al., 2015), post-dating the emplacement of the Warnie Volcanic Province. We propose that the Kappa I well represents a succession of volcaniclastic and primary volcanic rocks that was highly altered by hydrothermal fluids.

\subsection{Structural Controls on the Emplacement of the Warnie Volcanic Province}

From the late Triassic to the early Jurassic, the Eromanga Basin was subject to an east-west compressional event named the Hunter-Bowen event (Kulikowski \& Amrouch, 2017), which uplifted the basin and inverted the major highs. Subsequently, the basin underwent postcompressional flexural relaxation with the resultant accommodation space infilled by the Middle to Late Jurassic succession discussed within this manuscript (Lowe-Young, 1997). During this time, a strike-slip extensional regime is thought to have been present in southwest Queensland (Kulikowski et al., 2018). In this context, it is interesting to consider whether the stress regime of the Cooper Basin helped to control the location and morphology of igneous rocks within the WVP and, more broadly, the location of the WVP within central Australia.

\subsection{The Influence of Basement Structure on the Location of Igneous Rocks}

Within other basins, such as those in the North Atlantic, it has been noted how the location of igneous intrusions and volcanism is controlled by the basin structure, in particular the location of major faults (Schofield et al., 2017; McLean et al., 2017; Hardman et al., 2019). To investigate whether basement structure and faulting had a direct control on volcanism erupted during the Jurassic, we have utilised the 3D seismic reflection datasets available.

The basin structure of the eastern Nappamerri Trough is largely obscured by the thick Cooper and Eromanga Basin fill and the highly reflective coals of the Permian Toolachee and Patchawarra Fms that make imaging of deeper sediments difficult. Of all the 3D seismic reflection surveys available for this study, only the Winnie 3D survey imaged reflections 2800 ms deep within the Nappamerri Trough (Fig. 3)(approximately $4.3 \mathrm{~km}$ subsurface depth based on the Charal-I time-depth relationship). Notably, the exact lithology of this reflection is unclear, largely due to the lack of any intersections in the Central Nappameri 
616 wells. Unlike the flat-lying Cooper and Eromanga stratigraphy, these deep reflections were often inclined at an angle of $\sim 10^{\circ}$ (taken with the scale set so that Is TWT depth $=1 \mathrm{~km}$ distance laterally). Although not confidently picked throughout the whole of the Winnie 3D survey, the reflections can be mapped over an area of $\sim 600 \mathrm{~km}^{2}$ (Fig. I8B). We interpret these to represent the top Basement in the Nappamerri Trough.

When mapped and imaged in plan view, it is clear that the most major offset (a $\sim 400 \mathrm{~ms}$

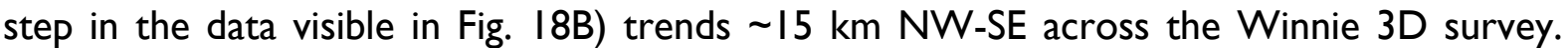
The same $400 \mathrm{~ms}$ step has been noted by previous mapping (SA Department for Manufacturing, Innovation, Trade, Resources and Energy, 2003) where it is visible on a top basement map in the eastern Nappamerri Trough. We interpret offset of the top basement as faulting and, so that it may be easily referred to throughout the text, name the major 400 ms offset the Central Nappamerri Fault.

In order to better relate the igneous activity in the area to the basement structure the distribution of the monogenetic vents within the Winnie 3D survey is considered with respect to these deep basement reflectors. Beneath the vents and volcanoes of the Winnie 3D survey, the seismic reflection data exhibited a velocity pull-up effect that could either represent shallow high velocity material (i.e., the vents or volcanoes themselves) or a high velocity feeder zone representing a vertical column of igneous rock or hydrothermally altered host rock. This effect was particularly obvious on the well-imaged Toolachee Fm., which was mapped to constrain the distribution of the pull-up effects or vents throughout the area (Fig. 18A). Underlying the volcanoes are dark patches that are clearly distinguished from the fluvial channels that make up the Toolachee Fm. (Fig. I8A). We have interpreted these as vents that are either hydrothermal vents or basaltic dykes. The position of these vents was highlighted and superimposed on top of the image of the basement reflections (Fig. 18B). The vents broadly fall into two groups, one to the south of the Central Nappamerri Fault and one to the NE of the Central Nappamerri Fault (Fig. 17 and 18B). These groups fall adjacent to the Top Basement reflections or directly above visible offset in the basement where it deepens to $>3600 \mathrm{~ms}$ and is no longer mappable, strongly implying a pervasive structural control on the location of vents in the Winnie 3D survey.

We also superimposed the location of the Madigan 3D volcanoes on top of the SA Department for Manufacturing, Innovation, Trade, Resources and Energy (2003) basement map (Fig. 17). Like the igneous rocks in the Winnie 3D survey, the two volcanoes imaged in 
the Madigan 3D survey sit atop the tip of the $25 \mathrm{~km}$ Challum Fault and atop a second, $\sim 5$ $\mathrm{km}$ fault northwest of the main Challum Fault. The volcanics seem to be located at the stepover between two faults, suggesting it may be a small releasing bend. This reinforces the idea that the location of igneous rocks was largely controlled by zones of weakness within the basins.

\subsubsection{The Influence of Discontinuities and Faults within the Eromanga Succession on the Morphology of lgneous Rocks}

The idea that structure was the principle control on the nature of the volcanics in the WVP can be extended to the morphology of the igneous rocks. In order to consider how basin structure controlled the morphology of igneous rocks within the Nappamerri Trough, the Winnie 3D survey was used to map the length, width and elongate direction of the volcanoes, lava flows and intrusions (Fig. 19). The high quality of the Winnie 3D survey facilitated confident mapping of the outline of individual volcanic events, however, the Gallus 2D and Snowball 3D surveys were not considered as the outline of individual volcanics could not be picked confidently. The data shows that igneous rocks in the area are typically twice as long as they are wide (Fig. 19). Furthermore, almost all the igneous rocks are elongated in a NW-SE direction, closely matching the strike of the faults within the Nappamerri Trough. It is clear that during eruption and emplacement of the igneous rocks, the basin structure exerted a strong control on the morphology of lava flows and igneous intrusions.

In vertical seismic reflection sections, faulting of the Eromanga Basin stratigraphy is not obvious within the Winnie 3D survey, largely due to the considerable noise within the section. However, spectral decomposition produced for the Top Volcanics horizon images discontinuities (shown as black lines) within the colour blend (Fig. 20). These discontinuities are not thought to be a product of the acquisition and processing of the seismic data, due to their non-linear nature and their coincidence with other geological features such as the igneous rocks and the CNF. When mapped, the features form a series of largely NE-SW trending lineaments (Fig. 20). Although imaging of the discontinuities is best in the SW of the survey, where there are fewer igneous rocks, it is evident that many of the igneous rocks are aligned with these features, suggesting they must have exerted some topographical or structural control when the igneous rocks were erupted or emplaced into the Nappamerri Trough (Fig. 20). As they do not resemble any sedimentary features such as valleys or fluvial 
systems, we interpret these features to be faulting or fracturing of the Eromanga succession above the Nappamerri Trough.

Determining the tectonic activity responsible for the faulting within the Nappamerri Trough and, hence, the location and morphology of igneous rocks within the WVP is difficult due to the complex structural and stress history of the Cooper Basin. Throughout the basin, a conjugate set of large NNE-SSW and field scale SE-NW striking dextral strike-slip faults developed under SSE-NNW strike-slip stress conditions (Kulikowski et al., 2018). This is pertinent when applied to the central Nappamerri Trough, as Kulikowski et al. (2018) identified a series of vertical SE-NW structural lineaments with normal displacement to no displacement. Due to their vertical nature, it is thought that these faults developed as strike slip faults during successive periods of flexural relaxation or sag. The faulting identified within this study is also determined to consist of little offset with an orientation that matches that of the strike-slip faulting determined by Kulikowski et al., (20l8) (Fig. 20). We surmise that sag within the basin produced a series of faults that controlled the morphology of igneous rocks in the WVP.

\subsection{The Broader Record of Jurassic Volcanism in Eastern Australia}

We believe it is important to consider the WVP in the context of the broader record of Jurassic volcanic activity in eastern Australia (Table 2 \& Fig. 2I). Coeval with the eruption of the WVP, the Eromanga Basin was undergoing post-compressional flexural relaxation with thermally controlled subsidence in the absence of significant fault control (Gallagher \& Lambeck, 1989). Subsidence has been attributed to subduction of the Pacific plate beneath southern and eastern Australia, during which time rifting also initiated between Australia and Antarctica (Griffiths, 1975; Johnstone et al., 1973).

Evidence for Jurassic volcanic activity is pervasive throughout the sedimentary basins of eastern Australia, manifested by volcanic arc-derived sediment within the Eromanga Basin (Boult et al., 1998), silicic tuffs in the Surat Basin (Wainman et al., 2015) and widespread volcanogenic zircons within the Eromanga Basin (Bryan et al., 1997). This volcaniclastic material is thought to be derived from an acid to intermediate volcanic arc positioned off the coast of Queensland during the Jurassic, however, the remnants of this arc volcanism are yet to be identified (Paton, 1986, Boult et al., 1997). Jurassic alkali basalt has been 
711 intersected on the Marion Plateau ( 400 km east of Townsville in Queensland), although this may also be related to rifting in the region during the Jurassic (Isern et al., 2002).

Around $1500 \mathrm{~km}$ south of the Marion Plateau, mafic and ultramafic igneous rocks are noted throughout the Eastern Highlands and Sydney Basin. Dykes of the Sydney area intrude rocks as young as $235 \mathrm{Ma}$ with $\mathrm{K}-\mathrm{Ar}$ dating suggesting ages of between 193 and $46.9 \mathrm{Ma}$ (McDougall and Wellman, 1976, Embleton et al., 1985, Pells, 1985). To the north west of the Syndey Basin, in New South Wales, lower Jurassic intrusions and volcanics of the Garawilla alkali basalts are noted in the Gunnedah Basin (195-I4I Ma) (Sutherland, 1978, Pratt, 1998, Gurba \& Weber, 200I). The intermediate to mafic Dubbo volcanics are also recognised in New South Wales (236-170 Ma) (Dulhunty, 1976, Embleton et al., 1985, Black, 1998, Warren et al., 1999). Further south of the Sydney and Gunnedah basins, Jurassic volcanics are scattered throughout Victoria and Tasmania (Veevers \& Conaghan, 1984). These include voluminous tholeiitic intrusions in Tasmania (183 Ma) that are thought to have been buried under a thick pile of largely eroded extrusive volcanics that have a detrital zircon age range of I82 $44 \mathrm{Ma}$ (Sutherland, 1978; McDougall \& Wellman, 1976, Bromfield et al., 2007, Ivanov et al., 2017). In Eastern Victoria, Jurassic activity included a 191 Ma dyke swarm of alkali basalts (Soesoo et al., 1999). The geochemical source characteristics of the Eastern Victoria alkalia basalts are suggestive of subcontinental lithospheric mantle, like the proposed source of the Late Cenozoic Newer Volcanic Province in western Victoria (Elburg \& Soesoo, 1999).

Around $1000 \mathrm{~km}$ south of the WVP, the Wisanger Basalt is a $\sim 170 \mathrm{Ma}, 20 \mathrm{~km}$ fragmented lava flow emplaced on top of Permian fluviatile sediments on Kangaraoo Island (McDougall \& Wellman, 1976). Geochemically, it is similar to the Tasmanian and Antarctic tholeiitic dolerite and basalts that are usually attributed to the Ferrar Large Igneous Province and extension that latterly resulted in the separation of Australia and Antarctica (Compston et al., 1968; Milnes et al., 1982). Of note in South Australia, Jurassic kimberlites record the extension of Mesozoic kimberlites found along the margin of southern Gondwana, above the subducting Pacific plate (Tappert et al., 2009), differing petrologically from the predominantly basaltic volcanism found elsewhere in eastern Australia.

Plate reconstructions indicate that the Eromanga Basin was located at significant distances (at least $750 \mathrm{~km}$ ) from the oceanic trench of the subducting Pacific plate (Veevers \& Conaghan, 1984; Ivanov et al., 2017) (Fig. 2I). We therefore believe the Warnie Volcanic Province to be an intraplate volcanic province and, as the origin of intraplate volcanism can 
743 often be contentious (Conrad et al., 20II), it is important to consider the source of this volcanism and implications for the formation of intraplate volcanism.

\subsection{The Origin of the Warnie Volcanic Province}

The WVP was located far from active plate boundaries during the Jurassic (Fig. 2I). When considering the source of intraplate volcanism, several different mechanisms must be considered:

- The presence of a mantle plume

- Asthenospheric upwelling due to extension

- Local scale mantle convection

Mantle plumes are typically associated with the eruption of voluminous flood basalt provinces that often mark the earliest volcanic activity of major hot spots (Richards et al., 1989). Furthermore, mantle plumes cause dynamic uplift of the land's surface of up to several hundred kms followed by surface subsidence due to the withdrawal of mantle plume material and loading of the crust with the volcanic sequence (Nadin et al., 1997; Dam et al., 1998; Hartley et al., 20II; Hardman et al., 2018). No evidence of major surface uplift in the Cooper and Eromanga Basins is coeval with the emplacement and eruption of the WVP (Hall et al., 2016). Furthermore, subsidence and sag throughout the emplacement of the WVP is minor, with no large changes in sedimentary facies noted throughout the Jurassic lower non-marine Eromanga succession (Alexander \& Hibburt, 1996). No major crustal and/or lithospheric extension is evidenced by the lack of major Jurassic faults, during a time in which the basin underwent post-compressional flexural relaxation in a strike slip extensional regime (Lowe-Young, 1997; Kulikowski et al., 2018). Furthermore, the small spatial area covered by the Warnie Volcanic Province $\left(\sim 7500 \mathrm{~km}^{2}\right.$ within the Nappamerri Trough area) and, by extension, the volume of magma emplaced, is too low to be related to a mantle plume source (Conrad et al., 20II).

Low-effusive volcanism occurring within tectonic plates has been also attributed to several locally operating processes, such as minor upwelling plumes, downwelling drops and sub-lithospheric or edge-driven convection (Courtillot et al., 2003; Ballmer et al., 2009; Conrad et al., 20II). In the case of edge-driven convection, mantle flow can induce upwelling and volcanism through interaction with lithospheric or asthenospheric heterogeneities (Conrad et al., 20II; Davies \& Rawlinson, 2014). In the Newer Volcanic Province in South 
774 Australia, $<5 \mathrm{kyr}$ volcanism formed as a product of edge driven convection is noted to consist of basaltic monogenetic volcanoes $<4 \mathrm{~km}^{2}$ in size covering an area of up to 40,000 $\mathrm{km}^{2}$ (Demidjuk et al., 2007; Davies \& Rawlinson, 20I4). This style of volcanism (basaltic, with individual volcanoes like Mount Gambier of a similar scale to the volcanoes imaged in the Nappamerri Trough area $(\sim 1.5 \times 1.5 \mathrm{~km}))$ and the areal extent $\left(7500 \mathrm{~km}^{2}\right.$ that could be extended to almost $20,000 \mathrm{~km}^{2}$ if the magnetic anomalies are found to be igneous in nature) are similar in scale to the igneous rocks in the Newer Volcanic Province. Convection within the asthenosphere can be induced by changes in lithospheric thickness. Although not much is known about the crustal structure below the eastern Nappamerri Trough, seismic reflection profiles have revealed that Devonian troughs to the east of the study area are associated with crustal thinning of 7 - $10 \mathrm{~km}$ (Mathur, 1983). Furthermore, on a continental scale, the Moho is observed to shallow to $\sim 20 \mathrm{~km}$ below the Cooper Basin (and more broadly, Central Australia) (Fig. 2I)(Kennett et al., 20II). Therefore, there is observable lithospheric thinning below the basins in Central Australia that could have produced edge driven convection.

However, because Central Australia was relatively inactive during the Jurassic, we must consider driving mechanisms for asthenospheric flow beneath the continent during the eruption and emplacement of the WVP. As we have already detailed, the Pacific plate was subducting beneath eastern Australia during the Jurassic. In intraplate volcanic provinces adjacent to subduction zones (e.g. Western North America, China), there is a causal link between subduction and intraplate volcanism, in that subduction below the continental crust acts as a driving force for asthenospheric shear and, hence, the mantle upwelling that produces intraplate volcanism (Conrad et al., 20II; Tang et al., 20I4; Zhou et al., 2018). If the extension in the area during the Jurassic is not great enough to stimulate volcanism, then an alternative model may involve rapid asthenospheric shear produced by the subducting Pacific Plate, localised beneath SW Queensland due to edge driven convection.

We propose a model for the Warnie Volcanic Province based on our understanding of the lithospheric and geodynamic state of Central Australia in the Jurassic. We propose that asthenospheric shear above the subducting pacific plate stimulated mantle flow below Australia (Fig. 20B). Localisation of mantle flow occurred beneath southwest Queensland because of edge driven convection lead to emplacement of the Warnie Volcanic Province above the Nappamerri Trough. Despite our proposed model, we strongly believe that more work needs to be conducted on the area before it can be concluded what the source of the 
WVP is. In the Newer Volcanic Province of southeastern Australia, geochemistry, major and trace element analysis, provided insights into the formation of a volcanic province through edge driven convection (Demidjuk et al., 2007). More recent geochemical and geophysical insights have furthered this discussion studies suggesting additional felsic asthenospheric input (Sutherland et al., 20I4), shear-driven upwelling (Oosting et al., 2016) and intermittent volcanism through interaction of transient mechanisms with the passage of a mantle plume (Rawlinson et al., 2017). As such, we would strongly recommend further studies to be conducted on the geochemical signature of the basalts of the WVP.

Due to its low volume, small areal extent and predominantly basaltic nature, we do not believe that the WVP was the source of the volcanically derived sediment that was distributed throughout much of Australia during the Mesozoic (Boult et al., 1998; MacDonald et al., 2013; Barham et al., 2016). However, our findings raise the possibility that other, yet unidentified, intra-basinal volcanic sources may contribute to Mesozoic volcanogenic sedimentation in eastern Australia.

Finally, it must be considered why the WVP has not been documented until now despite the presence of igneous rocks being known for over three decades. By our estimates, only $0.13 \%$ of the wells drilled in the Cooper Basin between 1959 and 2015 drilled the WVP (based on Hall et al., 2016's estimate of the number of wells), with 35 years of exploration since the first well that drilled the volcanics. This is despite the WVP occupying $\sim 6 \%$ of the geographic extent of the Cooper Basin. Largely, this is due to the lack of data and attention given to the Nappamerri Trough region until recently. Acquisition of the high-quality Winnie 3D seismic reflection survey facilitated confident delineation of the WVP. This study also underlines the importance for collaboration between industry and academia. Whilst igneous rocks have been described within industry reports and imaged within data acquired, they have been overlooked within the literature. The obscurity of the WVP in an area of such intense exploration points to the probability of other undiscovered volcanic provinces globally. It is therefore an important analogue in the search for undiscovered intraplate volcanism that may inform our understanding of the mantle processes occurring beneath continental interiors. 
837

\section{Conclusions}

838 We have integrated seismic, well, gravity and magnetic data and clarified the extent and character of igneous rocks emplaced above the Nappamerri Trough of the Cooper Basin within Eromanga Basin stratigraphy. Monogenetic volcanoes, igneous intrusions and altered compound lava flows extending over $\sim 7500 \mathrm{~km}^{2}$ are proposed to have been active between I80 - I60 Ma forming part of the proposed 'Warnie Volcanic Province.' Regionally, the morphology and distribution of igneous rocks is controlled by basement structure. On a continental scale, we interpret the Warnie Volcanic Province to be a product of intraplate convective upwelling above the subducting Pacific slab.

\section{Acknowledgements}

We wish to thank Santos Ltd. for providing us with the Snowball 3D seismic survey. In particular we wish to thank Jenni Clifford and Lance Holmes who provided helpful feedback and 2D seismic lines covering the Lambda I, Orientos 2 and Warnie East I wells. We also wish to thank Beach Energy, in particular Rob Menpes, for the helpful discussions and feedback on the manuscript in addition to helping us with the analysis of the magnetic data. The work contained in this paper contains work conducted during a PhD study undertaken as part of the Natural Environment Research Council (NERC) Centre for Doctoral Training (CDT) in Oil \& Gas [grant number NEM00578X/I] and is fully funded by NERC whose support is gratefully acknowledged. Lastly, the two anonymous reviews of the manuscript are thanked for their insightful and constructive comments that significantly improved the work presented. 


\section{I. References}

Aarnes, I., Planke, S., Trulsvik, M. and Svensen, H., 20I5. Contact metamorphism and thermogenic gas generation in the Vøring and Møre basins, offshore Norway, during the Paleocene-Eocene thermal maximum. Journal of the Geological Society, I72, 588-598.

Alexander, E.M. and Hibburt, J.E., 1996, Petroleum Geology of South Australia, Volume 2: Eromanga Basin.

Allen P., 1998. Kappa I Well Completion Report. Compiled for Santos Limited.

Archer, S.G., Bergman, S.C., lliffe, J., Murphy, C.M. and Thornton, M., 2005. Palaeogene igneous rocks reveal new insights into the geodynamic evolution and petroleum potential of the Rockall Trough, NE Atlantic Margin. Basin Research, I7, I7I-20I.

Apak, S.N., Stuart, W.J., Lemon, N.M. and Wood, G., 1997. Structural evolution of the PermianTriassic Cooper Basin, Australia: relation to hydrocarbon trap styles. AAPG bulletin, 8I, 533-555.

Ballmer, M.V., Van Hunen, J., Ito, G., Bianco, T.A. and Tackley, P.J., 2009. Intraplate volcanism with complex age-distance patterns: A case for small-scale sublithospheric convection. Geochemistry, Geophysics, Geosystems, 10.

Barham, M., Kirkland, C.L., Reynolds, S., O'Leary, M.J., Evans, N.J., Allen, H., Haines, P.W., Hocking, R.M., McDonald, B.J., Belousova, E. and Goodall, J., 20I6. The answers are blowin'in the wind: Ultradistal ashfall zircons, indicators of Cretaceous super-eruptions in eastern Gondwana. Geology, 44, 643-646.

Bell \& Butcher, 2002. On the emplacement of sill complexes: evidence from the Faroe-Shetland Basin. Geological Society, London, Special Publications(2002), 197:307

Black L.p. 1998. SHRIMP zircon UIPb isotopic age dating of samples from the Dubbo I:250000 Sheet area, batch 2. Geological Survey of New South Wales, File GSI998/I27 (unpublished).

Boothby, P.G., 1986. Warnie East I Well Completion Report. Compiled for Delhi Petroleum Pty Ltd.

Boult, P.J., Ryan, M.J., Michaelsen, B.H., McKirdy, D.M., Tingate, P.R., Lanzilli, E. and Kagya, M.L., 1997. The Birkhead-Hutton (!) Petroleum System of the Gidgealpa Area, Eromanga Basin, Australia.

Boult, P.J., Lanzilli, E., Michaelsen, B.H., McKirdy, D.M. and Ryan, M.J., 1998. A new model for the Hutton/Birkhead reservoir/seal couplet and the associated Birkhead-Hutton (!) petroleum system. The APPEA Journal, 38, 724-744. 
890 Bromfield, K.E., Burrett, C.F., Leslie, R.A. \& Meffre, S., 2007. Jurassic volcani-clastic basaltic andesite dolerite sequence in Tasmania: new age constraints for fossil plants from Lune River. Australian Journal of Earth Sciences, 54, 965-974.

Bryan, S.E., Constantine, A.E., Stephens, C.J., Ewart, A., Schön, R.W. and Parianos, J., 1997. Early Cretaceous volcano-sedimentary successions along the eastern Australian continental margin: Implications for the break-up of eastern Gondwana. Earth and Planetary Science Letters, I53, 85-102 Bucknill, M., 1990. Orientos 2 Well Completion Report. Compiled for Delhi Petroleum Pty Limited. Burger, D. and Senior, B.R., 1979. A revision of the sedimentary and palynological history of the northeastern Eromanga Basin, Queensland. Journal of the Geological Society of Australia, 26, I2I-I33.

Compston, W., McDougall, I. and Heier, K.S., 1968. Geochemical comparison of the mesozoic basaltic rocks of Antarctica, South Africa, South America and Tasmania. Geochimica et Cosmochimica Acta, 32, 129-149.

Courtillot, V., Davaille, A., Besse, J. and Stock, J., 2003. Three distinct types of hotspots in the Earth's mantle. Earth and Planetary Science Letters, 205, 295-308.

Davies, D.R. and Rawlinson, N., 2014, On the origin of recent intraplate volcanism in Australia, Geology, 42, I03I-1034.

Demidjuk, Z., Turner, S., Sandiford, M., George, R., Foden, J. and Etheridge, M., 2007, U-series isotope and geodynamic constraints on mantle melting processes beneath the Newer Volcanic Province in South Australia, Earth and Planetary Science Letters, 26I, 5I7-533.

Draper, J.J. ed., 2002. Geology of the Cooper and Eromanga Basins, Queensland. Department of Natural Resources and Mines

Dulhunty, J.A. 1976. Potassium-argon ages of igneous rocks in the Wollar-Rylstone region, New South Wales. Royal Society of New South Wales, Journal and Proceedings 109, 35-39.

Elburg, M.A. \& Soesoo, A., 1999. Jurassic alkali-rich volcanism in Victoria (Australia): lithospheric versus asthenospheric source. Journal of African Earth Sciences, 29, 269-280.

Elliot, D.H. and Fleming, T.H., 2004. Occurrence and dispersal of magmas in the Jurassic Ferrar large igneous province, Antarctica. Gondwana Research, 7, 223-237.

Embleton B.J.J., Schmidt P.w., Hamilton L.H. \& Riley G.H. 1985. Dating volcanism in the Sydney Basin; evidence from K-Ar ages and palaeomagnetism. Geological Society of Australia, Journal 23, 243-248. Exon, N.F. and Burger, D., 198I. Sedimentary cycles in the Surat Basin and global changes of sea level. Bureau of Mineral Resources Journal of Australian Geology and Geophysics, 6, I53-I59. 
921 Fishwick, S., Heintz, M., Kennett, B.L.N., Reading, A.M. and Yoshizawa, K., 2008. Steps in lithospheric

922 thickness within eastern Australia, evidence from surface wave tomography. Tectonics, 27.

923 Gallagher, K. and Lambeck, K., 1989, Subsidence, sedimentation and sea-level changes in the 924 Eromanga Basin, Australia, Basin Research, 2, II5-I3I.

925 D.I. Gravestock, J.E. Hibburt, J.F. Drexel (Eds.), Petroleum Geology of South Australia, Volume 4: 926 Cooper Basin, Department of Primary Industries and Resources (1998), I-6

927 Greenstreet, C. 20I5. From play to production: the Cooper unconventional story - 20 years in the making. APPEA 2015 extended abstract.

Griffiths, J.R., 1975. New Zealand and the Southwest Pacific margin of Gondwanaland. In: K.S.W. Campbell (Editor), Gondwana Geology. A.N.U. Press, Canberra, 619- 637.

Grove, C., Jerram, D.A., Gluyas, J.G. and Brown, R.J., 2017. Sandstone diagenesis in sediment-lava sequences: exceptional examples of volcanically driven diagenetic compartmentalization in Dune Valley, Huab Outliers, NW Namibia. Journal of Sedimentary Research, 87, I3 |4- I 335.

Gurba, L.W. and Weber, C.R., 200I, Effects of igneous intrusions on coalbed methane potential, Gunnedah Basin, Australia, International Journal of Coal Geology, 46, II3-I3I.

Hall, L.S., Hill, A.J., Troup, A., Korsch, R.J., Radke, B.M., Nicoll, R.S., Palu, T., Wang, L. and Stacey, A., 2016, Cooper Basin Architecture and Lithofacies, Geoscience Australia.

Hall, L.S, Palu, T.J., Murray, A.P., Boreham, C.J., Edwards, D.S., Hill, A.J., Troup, A., 2018.

Hydrocarbon Prospectivity of the Cooper Basin, Australia. AAPG Bulletin.

940 Hardman, J.P., Schofield, N., Jolley, D.W., Holford, S.P., Hartley, A.J., Morse, S., Underhill, J.R., 941 Watson, D.A. and Zimmer, E.H., 2018. Prolonged dynamic support from the Icelandic plume of the 942 NE Atlantic margin. Journal of the Geological Society, 175, 396-4I0.

943 Hardman, J., Schofield, N., Jolley, D., Hartley, A., Holford, S. and Watson, D., 2019. Controls on the 944 distribution of volcanism and intra-basaltic sediments in the Cambo-Rosebank region, West of 945 Shetland. Petroleum Geoscience, 25, 7I-89.

946 Hillis, R.R., Morton, J.G.G., Warner, D.S. and Penney, R.K., 200I. Deep basin gas: A new exploration 947 paradigm in the Nappamerri Trough, Cooper Basin, South Australia. The APPEA Journal, 4I, I85-200.

948 Isern, A.R., Anselmetti, F.S. and Blum, P., 2002. Constraining Miocene sea level change from 949 carbonate platform evolution, Marion Plateau, northeast Australia, Sites II92-I 199. In Proceedings of 950 the Ocean Drilling Program. Initial Reports, 194, 88. 
951 Ivanov, A.V., Meffre, S., Thompson, J., Corfu, F., Kamenetsky, V. S., Kamenetsky, M.B. \& Dementrova, E. I., 20I7. Timing and genesis of the Karoo-Ferrer large igneous province: New high precision U-Pb data for Tasmania confirm short duration of the major magmatic pulse. Chemical Geology, 455, 3243.

Jerram, D.A. \& Widdowson, M. 2005. The anatomy of Continental Flood Basalt Provinces: geological constraints on the processes and products of flood volcanism. Lithos, 79, 385-405.

Johnstone, M.H., Lowry, D.C. and Quilty, P.G., 1973. The geology of South-western Australia - a review. J. Proc. R. Sot. West. Aus., 56: 5-I5.

Kapel, A., 1966. The Cooper's Creek Basin. The APPEA Journal, 6, 71-75.

Kelley, S. (2002) K-Ar and Ar-Ar Dating, in noble gases in geochemistry and cosmochemistry. In: Reviews in Mineralogy and Geochemistry, 47 (Ed. by D. Porcelli, C.J. Ballentine \& R. Wieler), 785818, Mineral Society America, Washington, DC.

Kennett, B., Salmon, M., Saygin, E. and AusMoho Working Group., AusMoho: the variation of Moho depth in Australia, Geophysical Journal International, I87, 946-958, 20 I I, doi:I0.1 I I /j.1365246X.2011.05194.x

Khair, H.A., Cooke, D. and Hand, M., 20I3. The effect of present day in situ stresses and paleostresses on locating sweet spots in unconventional reservoirs, a case study from Moomba-Big Lake fields, Cooper Basin, South Australia. Journal of Petroleum Exploration and Production Technology, 3(4), Pp.207-221.

Khair, H.A., Cooke, D. and Hand, M., 20I5. Paleo stress contribution to fault and natural fracture distribution in the Cooper Basin. Journal of Structural Geology, 79, pp.3 I-4I.

Kuang, K.S., 1985. History and style of Cooper? Eromanga Basin structures. Exploration Geophysics, 16(3), pp.245-248.

Kulikowski, D., Amrouch, K., Al Barwani, K.H.M., Liu, W. and Cooke, D., 20I5, September. Insights into the Tectonic Stress History and Regional 4-D Natural Fracture Distribution in the Australian Cooper Basin Using Etchecopar's Calcite Twin Stress Inversion Techbique. In International Conference \& Exhibition.

Kulikowski, D. and Amrouch, K., 2017. Combining geophysical data and calcite twin stress inversion to refine the tectonic history of subsurface and offshore provinces: A case study on the Cooper-Eromanga Basin, Australia. Tectonics, 36(3), pp.5I5-54I. 
981 Kulikowski, D., Amrouch, K., Cooke, D. and Gray, M.E., 2018, Basement structural architecture and

1

hydrocarbon conduit potential of polygonal faults in the Cooper-Eromanga Basin,

Australia, Geophysical Prospecting, v. 66, p. 366-396.

Lanzilli, E., 1999. The Birkhead Formation: reservoir characterisation of the Gidgealpa south dome and sequence stratigraphy of the Eromanga Basin, Australia (Doctoral dissertation, University of South Australia).

Liu, P., Mao, J., Cheng, Y., Yao, W., Wang, X. and Hao, D., 2017. An Early Cretaceous W-Sn deposit and its implications in southeast coastal metallogenic belt: Constraints from U-Pb, Re-Os, Ar-Ar geochronology at the Feie'shan W-Sn deposit, SE China. Ore Geology Reviews, 81, pp.112-122.

Lowe-Young, B.S., Mackie, S.I. and Heath, R.S., 1997. The Cooper-Eromanga petroleum system, Australia: Investigation of essential elements and processes.

MacDonald, J.D., Holford, S.P., Green, P.F., Duddy, I.R., King, R.C. and Backé, G., 20I3. Detrital zircon data reveal the origin of Australia's largest delta system. Journal of the Geological Society, I 70(I), pp.3-6.

Mackie, S., 2015, September. History of petroleum exploration and development in the Cooper and Eromanga basins. In AAPG/SEG International Conference \& Exhibition, Melbourne, Australia. Search and Discovery Article \#10814

Magee, C., Jackson, C.L. and Schofield, N., 2014. Diachronous sub-volcanic intrusion along deep-water margins: Insights from the Irish Rockall Basin. Basin Research, 26(I), pp.85-105.

Mathur, S.P., 1983, Deep crustal reflection results from the central Eromanga Basin,

Australia, Tectonophysics, v. 100, pp. 163-173.

McDougall, I. \& Wellman, P. 1976. Potassium argon ages for some Australian Mesozoic igneous rocks. Journal of the Geological Society of Australia, 23, 1-9.

McLean, C.E., Schofield, N., Brown, D.J., Jolley, D.W. and Reid, A., 2017. 3D seismic imaging of the shallow plumbing system beneath the Ben Nevis Monogenetic Volcanic Field: Faroe-Shetland Basin. Journal of the Geological Society, 174(3), pp.468-485

Meeuws, F.J., Holford, S.P., Foden, J.D. and Schofield, N., 2016. Distribution, chronology and causes of Cretaceous-Cenozoic magmatism along the magma-poor rifted southern Australian margin: Links between mantle melting and basin formation. Marine and Petroleum Geology, 73, pp.27I-298.

Meixner, T.J., Gunn, P.J., Boucher, R.K., Yeates, T.N., Richardson, L.M. and Frears, R.A., 2000. The nature of the basement to the Cooper Basin region, South Australia. Exploration Geophysics, 3I(2), Pp.24-32. 
Middleton, A.W., Uysal, I.T., Bryan, S.E., Hall, C.M. and Golding, S.D., 20I4. Integrating 40Ar-39Ar, $87 \mathrm{Rb}-87 \mathrm{Sr}$ and $147 \mathrm{Sm}-143 \mathrm{Nd}$ geochronology of authigenic illite to evaluate tectonic reactivation in an intraplate setting, central Australia. Geochimica et Cosmochimica Acta, 134, pp. I55-I74.

Middleton, A.W., Uysal, I.T. and Golding, S.D., 2015. Chemical and mineralogical characterisation of illite-smectite: Implications for episodic tectonism and associated fluid flow, central Australia. Geochimica et Cosmochimica Acta, 148, pp.284-303.

Millett, J.M., Hole, M.J., Jolley, D.W., Schofield, N. and Campbell, E., 2016. Frontier exploration and the North Atlantic Igneous Province: new insights from a $2.6 \mathrm{~km}$ offshore volcanic sequence in the NE Faroe-Shetland Basin. Journal of the Geological Society, I 73(2), pp.320-336.

Milnes, A.R., Cooper, B.J. and Cooper, J.A., 1982. The Jurassic Wisanger Basalt of Kangaroo Island, South Australia. Transactions of the Royal Society of South Australia, 106, Pp. I-I3.

Murray, C.G., 1994. Basement cores from the Tasman fold belt system beneath the Great Artesian Basin in Queensland. Department of Minerals and Energy, Queensland.

Nadin, P.A., Kusznir, N.J. and Cheadle, M.J., 1997, Early Tertiary plume uplift of the North Sea and Faeroe-Shetland basins, Earth and Planetary Science Letters, v. I 48, p. 109-I 27.

Nelson, C.E., Jerram, D.A. and Hobbs, R.W., 2009, Flood basalt facies from borehole data: implications for prospectivity and volcanology in volcanic rifted margins, Petroleum Geoscience, v. I5, p. 313-324.

Németh, K., 2010. Monogenetic volcanic fields: Origin, sedimentary record, and relationship with polygenetic volcanism. What is a Volcano?, 470, p.43.

Németh, K. and Kereszturi, G., 2015. Monogenetic volcanism: personal views and discussion. International Journal of Earth Sciences, 104(8), pp.2।31-2I 46.

Oostingh, K.F., Jourdan, F., Merle, R. \& Chiradia, M., 20I6. Spatio-temporal geochemical evolution of the $\mathrm{SE}$ Australian upper mantle deciphered from the $\mathrm{Sr}, \mathrm{Nd}$ and $\mathrm{Pb}$ isotope compositions of Cenozoic intraplate volcanic rocks. Journal of Petrology, 57, 1509 - 1530.

Pande, K., Cucciniello, C., Sheth, H., Vijayan, A., Sharma, K.K., Purohit, R., Jagadeesan, K.C. and Shinde, S., 2017. Polychronous (Early Cretaceous to Palaeogene) emplacement of the Mundwara alkaline complex, Rajasthan, India: 40 Ar/39 Ar geochronology, petrochemistry and geodynamics. International Journal of Earth Sciences, 106(5), pp.1487-1504.

Paton, I.M., 1986, The Birkhead Formation-a Jurassic petroleum reservoir, in D.I. Gravestock, P.S. Moore, and G.M. Pitt, (eds.), Contributions to the Geology and Hydrocarbon Potential of the Eromanga Basin: Geological Society of Australia Special Publication No. 12, p. 195-20I. 
Pells, P.J.N., 1985. Engineering geology of the Sydney Region, 407 pp. Routledge, London.

Pitkin, M.C., Wadham, T.H., McGowen, J.M. and Thom, W.W., 20I2, January. Taking the first steps: Stimulating the Nappamerri Trough resource play. In SPE Asia Pacific Oil and Gas Conference and Exhibition. Society of Petroleum Engineers.

Planke, S., Symonds, P.A., Alvestad, E. and Skogseid, J., 2000. Seismic volcanostratigraphy of large-volume basaltic extrusive complexes on rifted margins. Journal of Geophysical Research: Solid Earth, 105(B8), pp.19335-1935I.

Planke, S., Rasmussen, T., Rey, S.S. and Myklebust, R., 2005, January. Seismic characteristics and distribution of volcanic intrusions and hydrothermal vent complexes in the Vøring and Møre basins. In Geological Society, London, Petroleum Geology Conference series (Vol. 6, No. I, pp. 833-844). Geological Society of London.

Planke, S., Millett, J.M., Maharjan, D., Jerram, D.A., Abdelmalak, M.M., Groth, A., Hoffmann, J., Berndt, C. and Myklebust, R., 2017. Igneous seismic geomorphology of buried lava fields and coastal escarpments on the Vøring volcanic rifted margin. Interpretation, 5(3), PP.SK I6I-SKI77.

Pratt, W., 1998. Gunnedah Coalfield: notes to accompany the Gunnedah Coalfield regional geology (north and south maps). Report GSI998/505. New South Wales Department of Mineral Resources. Geological Survey of New South Wales, Sydney, II3 pp.

Rawlinson, N., Davies, D.R. \& Pila, S., 2017. The mechanisms underpinning Cenozoic intraplate volcanism in eastern Australia: insights from seismic tomography and geodynamic modelling. Geophysical Research Letters, 44, doi: I0.1002/2017GL0749II.

Reid, A.J., Korsch, R.J., Hou, B. and Black, L.P., 2009. Sources of sediment in the Eocene Garford paleovalley, South Australia, from detrital-zircon geochronology. Australian Journal of Earth Sciences, 56(SI), Pp.SI25-SI37.

Renaut, R.W., Jones, B., Tiercelin, J.J. and Tarits, C., 2002. Sublacustrine precipitation of hydrothermal silica in rift lakes: evidence from Lake Baringo, central Kenya Rift Valley. Sedimentary Geology, I 48(I-2), pp.235-257.

Reynolds, P., Holford, S., Schofield, N. and Ross, A., 2017. 3-D Seismic Imaging of Ancient Submarine Lava Flows: An Example From the Southern Australian Margin. Geochemistry, Geophysics, Geosystems.

Richards, M.A., Duncan, R.A. and Courtillot, V.E., 1989. Flood basalts and hot-spot tracks: plume heads and tails. Science, 246(4926), pp. I03-107.

Rider, M. and Kennedy, M., 20II. The Geological Interpretation of Well Logs. published by RiderFrench Consulting Ltd. 
1077 Russell, M. and Gurnis, M., 1994. The planform of epeirogeny: vertical motions of Australia during the Cretaceous. Basin Research, 6(2-3), pp.63-76.

"SA Department for Manufacturing, Innovation, Trade, Resources and Energy" (2003) National Geoscience Mapping Accord (NGMA) Cooper Eromanga Basins Project - Cooper Formation Depths. Bioregional Assessment Source Dataset. Viewed 27 November 2017, http://www.energymining.sa.gov.au/petroleum/data and_publications/seismic/cooper_and_e romanga_basin_mapping_products

Schofield, N. and Jolley, D.W., 2013. Development of intra-basaltic lava-field drainage systems within the Faroe-Shetland Basin. Petroleum Geoscience, 19(3), pp.273-288.

Schofield, N., Holford, S., Millett, J., Brown, D., Jolley, D., Passey, S.R., Muirhead, D., Grove, C., Magee, C., Murray, J. and Hole, M., 2017. Regional magma plumbing and emplacement mechanisms of the Faroe-Shetland Sill Complex: implications for magma transport and petroleum systems within sedimentary basins. Basin Research, 29(I), Pp.4I-63.

Scott, M.P., Stephens, T., Durant, R., McGowen, J., Thom, W. and Woodroof, R., 20I3, November. Investigating hydraulic fracturing in tight gas sand and shale gas reservoirs in the Cooper Basin. In SPE Unconventional Resources Conference and Exhibition-Asia Pacific. Society of Petroleum Engineers.

Segawa, J. and Oshima, S., 1975. Buried Mesozoic volcanic-plutonic fronts of the north-western Pacific island arcs and their tectonic implications. Nature, 256(55I2), p.I5.

Short, D.A., 1984. Lambda No.I Well Completion Report. Compiled for Delhi Petroleum Pty. Ltd. Soesoo, A., Bons, P. \& Elburg, M., 1999 Freestone dykes—an alkali-rich Jurassic dyke population in eastern Victoria. Australian Journal of Earth Sciences, 46 (I-2), I-9.

Smith, 1987. Vitrinite Reflectance/Maceral Analysis of the Warnie East I Well.

Stewart, A.K., Massey, M., Padgett, P.L., Rimmer, S.M. and Hower, J.C., 2005. Influence of a basic intrusion on the vitrinite reflectance and chemistry of the Springfield (No. 5) coal, Harrisburg, Illinois. International Journal of Coal Geology, 63( I-2), pp.58-67.

Stewart, A.J., Raymond, O.L., Totterdell, J.M., Zhang, W. \& Gallagher, R. 2013. Australian Geological Provinces, 2013.01 edition. scale 1:2 500 000. Geoscience Australia, Canberra, http://www.ga.gov.au/metadata-gateway/metadata/record/83860

Sun, X., 1997. Structural style of the Warburton Basin and control in the Cooper and Eromanga Basins, South Australia. Exploration Geophysics, 28(3), pp.333-339. 
1107 Sutherland, F.L., 1978. Mesozoic-Cainozoic volcanism of Australia. Tectonophysics, 48(3-4), pp.4I3-

1108

3

41109

51110

71111

8

9 $10^{1112}$

111113

12

131114

14

15

16

171116

18

191117

20

211118

22

231119

24

251120

26

271121

28

291122

30

311123

32

331124

341125

35

361126

37

381127

39

401128

41

421129

431130

44

45

461131

47

481132

49

501133

51

521134

531135

54

55

561136

571137

581137

591138

60

61

62

63

64

65 427.

Sutherland, F.L., Graham, I.T., Hollis, J.D., Meffre, S., Zwingmann, H., Jourdan, F. \& Pogson R.E., 2014. Multiple felsic events within post- 10 Ma volcanism, Southeast Australia: inputs in appraising proposed magmatic models. Australian Journal of Earth Sciences, 16, 24I- 267.

Tang, Y., Obayashi, M., Niu, F., Grand, S.P., Chen, Y.J., Kawakatsu, H., Tanaka, S., Ning, J. and Ni, J.F., 2014. Changbaishan volcanism in northeast China linked to subduction-induced mantle upwelling. Nature Geoscience, 7(6), pp.470-475

Tappert, R., Foden, J., Stachel, T., Muehlenbachs, K., Tappert, M. and Wills, K., 2009. Deep mantle diamonds from South Australia: A record of Pacific subduction at the Gondwanan margin. Geology, 37(I), pp.43-46.

Tarling, D.H., 1966. The magnetic intensity and susceptibility distribution in some Cenozoic and Jurassic basalts. Geophysical Journal International, I I (4), pp.423-432.

Thomson, K., and Schofield, N.. "Lithological and structural controls on the emplacement and morphology of sills in sedimentary basins." Geological Society, London, Special Publications 302.I (2008): $31-44$.

Tracey R, Bacchin M, \& Wynne P., 2008, In preparation. AAGD07: A new absolute gravity datum for Australian gravity and new standards for the Australian National Gravity Database. Exploration Geophysics.

Trude, J., Cartwright, J., Davies, R.J. and Smallwood, J., 2003, New technique for dating igneous sills, Geology, v. 3I, p. 813-8I6.

Tucker, R.T., Roberts, E.M., Henderson, R.A. and Kemp, A.I., 2016, Large igneous province or longlived magmatic arc along the eastern margin of Australia during the Cretaceous? Insights from the sedimentary record, Geological Society of America Bulletin, v. I28, p. I46I-I480.

Veevers, J.J. and Conaghan, P.J., 1984, Phanerozoic earth history of Australia, Oxford University Press, USA.

Wainman, C.C., Mccabe, P.J., Crowley, J.L. and Nicoll, R.S., 2015, U-Pb zircon age of the Walloon Coal Measures in the Surat Basin, southeast Queensland: implications for paleogeography and basin subsidence, Australian Journal of Earth Sciences, v. 62, p. 807-816.

Wainman, C.C., Reynolds, P., Hall, T., McCabe, P.J. and Holford, S.P., 2019. Nature and origin of tuff beds in Jurassic strata of the Surat Basin, Australia: Implications on the evolution of the eastern margin of Gondwana during the Mesozoic. Journal of Volcanology and Geothermal Research. 
1139 Warren, A.Y.E., Barron, L.M., Meekin, N.S., Morgan, E.J., Raymond, O.L., Cameron, R.G. \& ${ }_{2}^{1} 1140$ Colquhoun, G.P., 1999. Mesozoic Igneous Rocks. In Meakin, N.S. \& Morgan, E.J. (Compilers). Dubbo 31141 I:250 000 Geological Sheet SI/55-4, 2nd edition, Explanatory Notes, PP. 3/3-328. Geological 4 51142 Survey of New South Wales, Sydney. ${ }_{7}^{6} 1143$ Watson, D., Schofield, N., Jolley, D., Archer, S., Finlay, A.J., Mark, N., Hardman, J. and Watton, T., 81144 2017. Stratigraphic overview of Palaeogene tuffs in the Faroe-Shetland Basin, NE Atlantic 101145 11

Watts, K.J., 1987, The Hutton Sandstone-Birkhead Formation Transition, ATP 269P(I), The APEA Journal, Volume 27 Number I, p 215 - 228.

White, J.D. and Ross, P.S., 2011. Maar-diatreme volcanoes: a review. Journal of Volcanology and Geothermal Research, 201(1-4), pp.1-29.

Yew, C.C. and Mills, A.A., 1989. The occurrence and search for Permian oil in the Cooper Basin, Australia.

Zhou, Q., Liu, L. and Hu, J., 2018, Western US volcanism due to intruding oceanic mantle driven by ancient Farallon slabs, Nature Geoscience, v. II, p. 70. 
I2. Tables

\begin{tabular}{|l|l|l|l|l|}
\hline Seismic Survey & $\begin{array}{l}\text { Acquisition } \\
\text { Date }\end{array}$ & $\begin{array}{l}\text { Acquisition } \\
\text { Company }\end{array}$ & Areal Coverage & Data Type \\
\hline Winnie & 2012 & $\begin{array}{l}\text { Drillsearch Energy } \\
\text { Ltd. And } \\
\text { WesternGeco }\end{array}$ & $1050 \mathrm{~km}^{2}$ & $3 \mathrm{D}$ \\
\hline Snowball & 2016 & Santos Ltd. & $1698 \mathrm{~km}^{2}$ & $3 \mathrm{D}$ \\
\hline Gallus & 2012 & $\begin{array}{l}\text { Beach Energy and } \\
\text { Icon Energy }\end{array}$ & $420 \mathrm{~km}$ & $2 \mathrm{D}$ \\
\hline Madigan & 1996 & Santos Ltd. & $584 \mathrm{~km}^{2}$ & $3 \mathrm{D}$ \\
\hline
\end{tabular}

Table I: List of the seismic surveys that were determined to contain igneous rocks and utilised within this study.

\begin{tabular}{|l|l|l|l|}
\hline Location of Igneous Rocks & Name & Age & Key Reference \\
\hline Marion Platea & $\mathrm{n} / \mathrm{a}$ & Jurassic & Isern et al., 2002 \\
\hline Eastern Highlands and Sydney Basin & $\mathrm{n} / \mathrm{a}$ & $235-46.9 \mathrm{Ma}$ & Pells, I985 \\
\hline Gunnedah Basin & Garawilla Basalts & $195-141 \mathrm{Ma}$ & Gurba \& Weber, 200I \\
\hline New South Wales & Dubbo Volcanics & $236-170 \mathrm{Ma}$ & Warren et al., I999 \\
\hline Eastern Victoria & $\mathrm{n} / \mathrm{a}$ & $191-179 \mathrm{Ma}$ & Elburg \& Soesoo, I999 \\
\hline Tasmania & $\mathrm{n} / \mathrm{a}$ & $183-182 \mathrm{Ma}$ & Ivanov et al., 20I7 \\
\hline Kangaroo Island & Wisanger Basalt & $170 \mathrm{Ma}$ & Milnes et al., I982 \\
\hline
\end{tabular}

Table 2: List of Cretaceous igneous rocks in Eastern Australia. Where possible, a name and age range has been given. Each location is discussed within the text. 

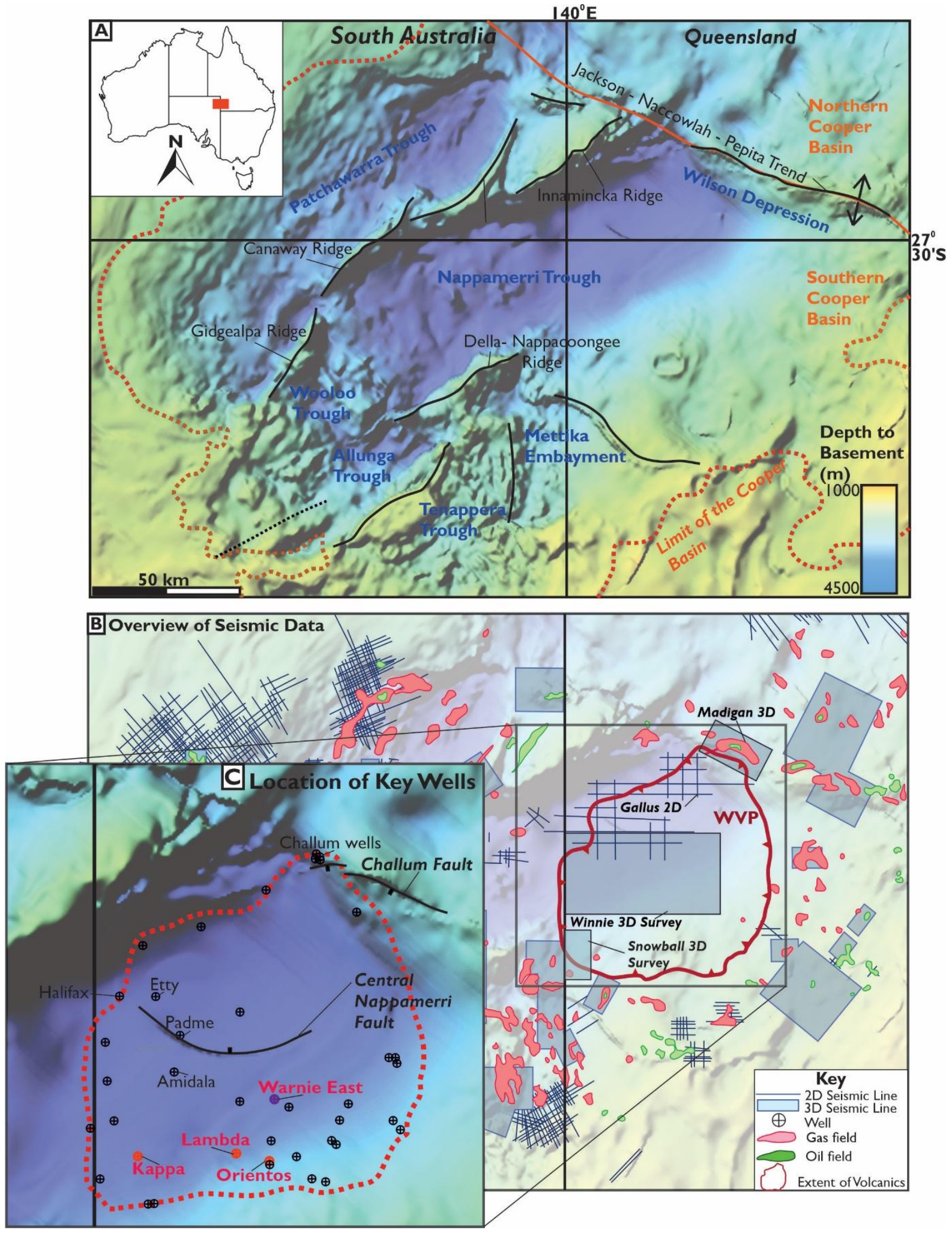

Figure I. Location map of the Warnie Volcanic Province and the data available. A Top basement map adapted from the SA Department for Manufacturing, Innovation, Trade, Resources and Energy (2003). Key structures of the southern Cooper Basin highlighted. B Location map highlighting the 
1167 location of the Warne Volcanic Province within the Cooper Basin. Top basement map superimposed ${ }_{2}^{1} 1168$ with the location of $3 D$ and 2D seismic surveys utilised in this study and the location of key 31169 exploration wells. C Location map of the wells drilled within the Warnie Volcanic Province that 4 were analysed during this study. Wells that intersected igneous rocks are highlighted in red. The 81172 are noted. 
1

2

3

4

5

6

7

8

9

10

11

12

13

14

15

16

17

18

19

20

21

22

23

24

25

26

27

28

29

30

31

32

33

34

35

36

37

381175

39

401176

41

421177

43

441178

451179

471180

48

49

$50^{1181}$

51

52

53

54

55

56

57

58

59

60

61

62

63

64

65

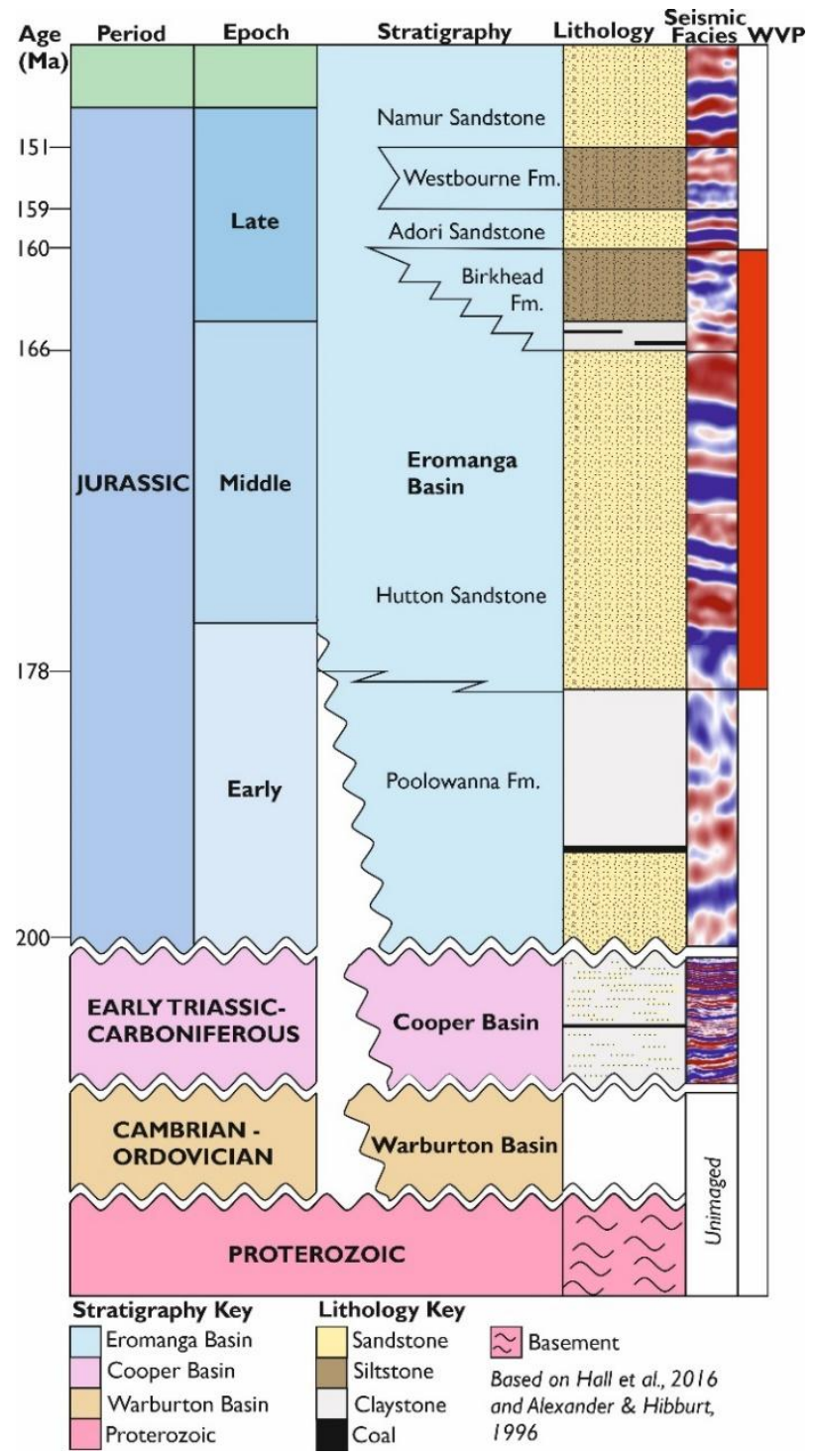

Figure 2. Stratigraphic column for the stratigraphy discussed within the paper, based on the work of Alexander \& Hibburt (1996), Hall et al. (2016) \& Reid et al. (2009). Seismic facies for each section is taken from the Winnie 3D survey of the eastern Nappamerri Trough. Rough stratigraphic location of the WVP highlighted. 


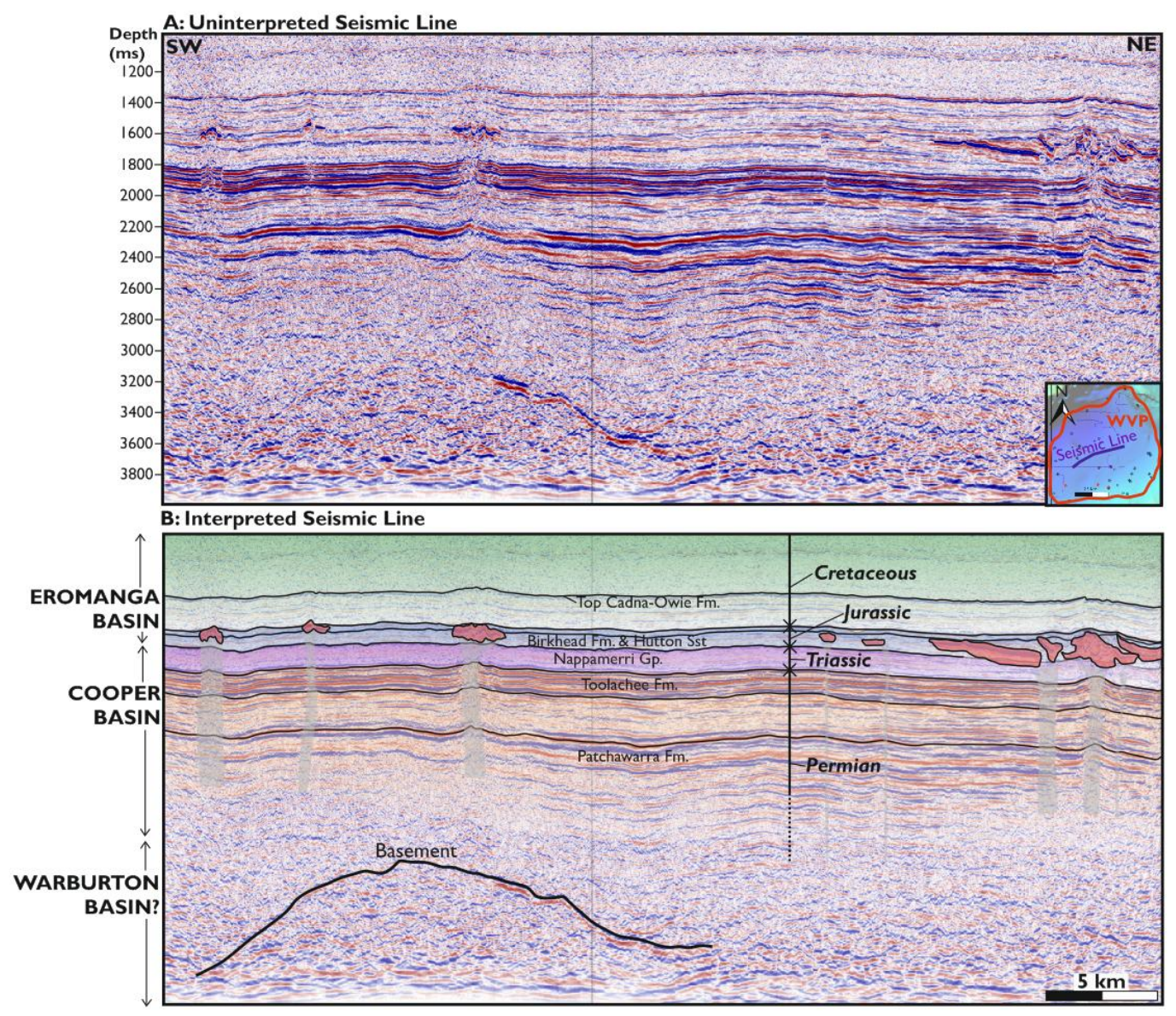

Figure 3. Seismic line from the Winnie 3D survey of the Nappamerri Trough highlighting the broad stratigraphy of the study area. A Uninterpreted line. B Interpreted line. Note the stacked nature of the Eromanga, Cooper and Warburton Basins and the stratigraphic location of the Warne Volcanic Province. 

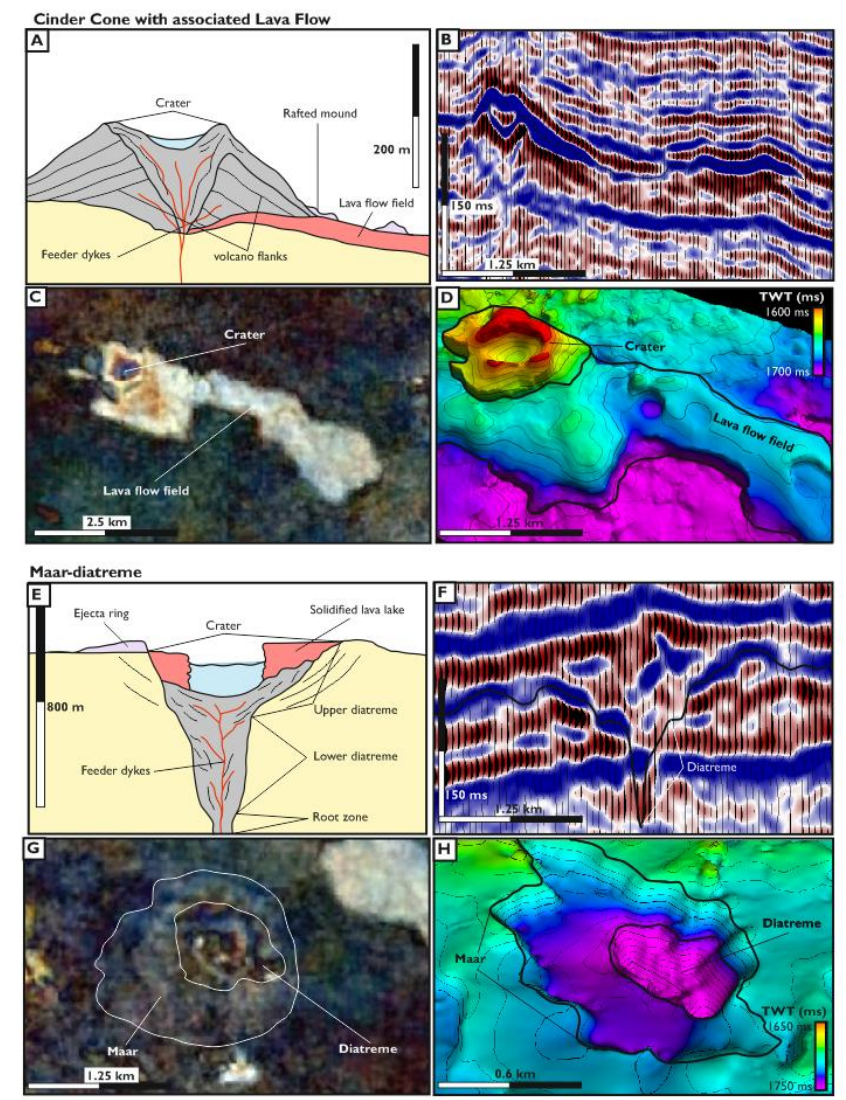

Figure 4. Examples of different monogenetic vents. A Cross section through a cinder cone, adapted from Németh \& Kereszturi (2015). B Seismic line across a cinder cone and lava flow, taken from the Winnie 3D survey, highlighting the general morphology, seismic response. Note the characteristic eye shape within the centre of the vent. C Plan view spectral decomposition of the cinder cone in B highlighting how different it is from the surrounding sediments. D Oblique view of the same cinder cone shown in TWT. E Cross section through a Maar-diatreme, adapted from Németh \& Kereszturi (20I5). F Seismic line across a proposed Maar-diatreme from the Winnie 3D survey. Note how it cuts down into the subsurface with an internally chaotic seismic response. G Plan view spectral decomposition of the Maar-diatreme within the Winnie 3D survey. $\mathbf{H}$ Oblique, TWT view of the proposed Maar-diatreme. 


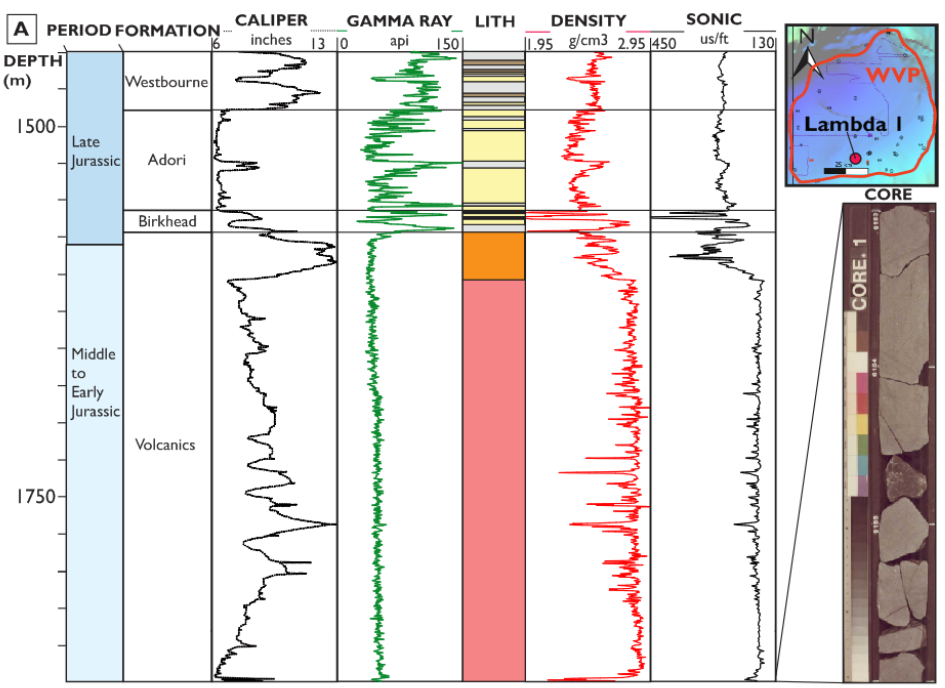

Figure 5. Well data for the volcanics from the Lambda-I well. A Composite log of the volcanic succession in the Lambda-I well. Includes an image of the core taken from the base of the volcanic successon. B Vitrinite reflectance curve for the succession above the volcanics taken from Boothby (1986). Little thermal effect is observed. C Velocity histogram of the Lambda-I volcanics superimposed on Nelson et al.'s (2009) velocity histogram of Tabular basalt. 
1

2

3

4

5

6

7

8

9

10

11

12

13

14

15

16

$17^{1208}$

18

191209

201210

21

22

231211

24

251212

26

27

$28^{1213}$

29

301214

31

321215

33

34

35

36

37

38

39

40

41

42

43

44

45

46

47

48

49

50

51

52

53

54

55

56

57

58

59

60

61

62

63

64

65

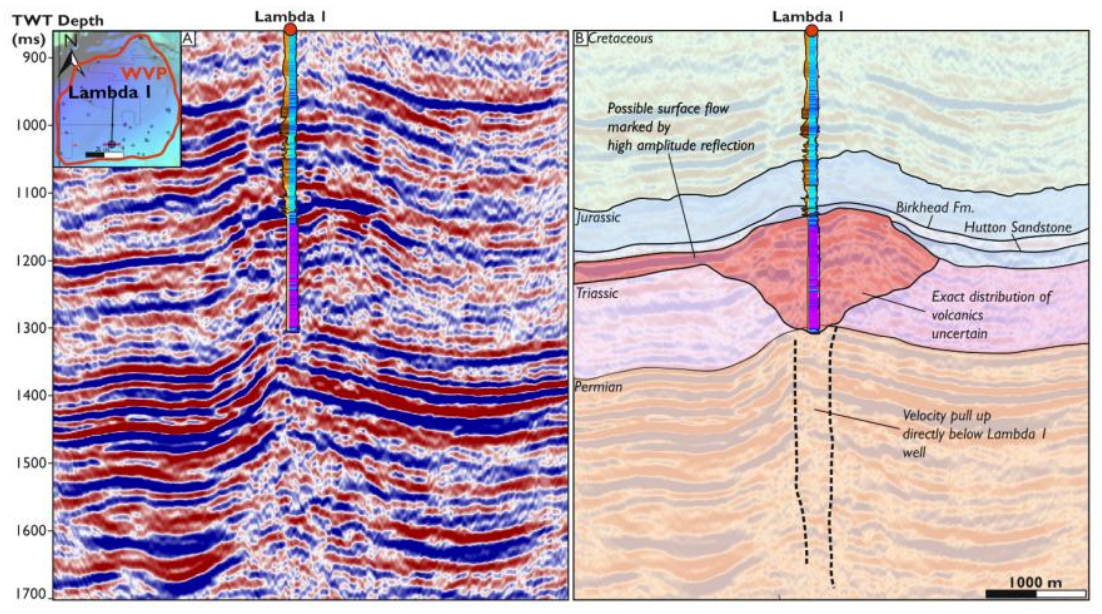

Figure 6. West to east seismic line running across the Lambda I well. The extent of the Lambda I vent has been inferred base on the thickness of volcanics within the well. 
1

2

3

4

5

6

A) Spectral Decomposition of Winnie 3D Volcanics

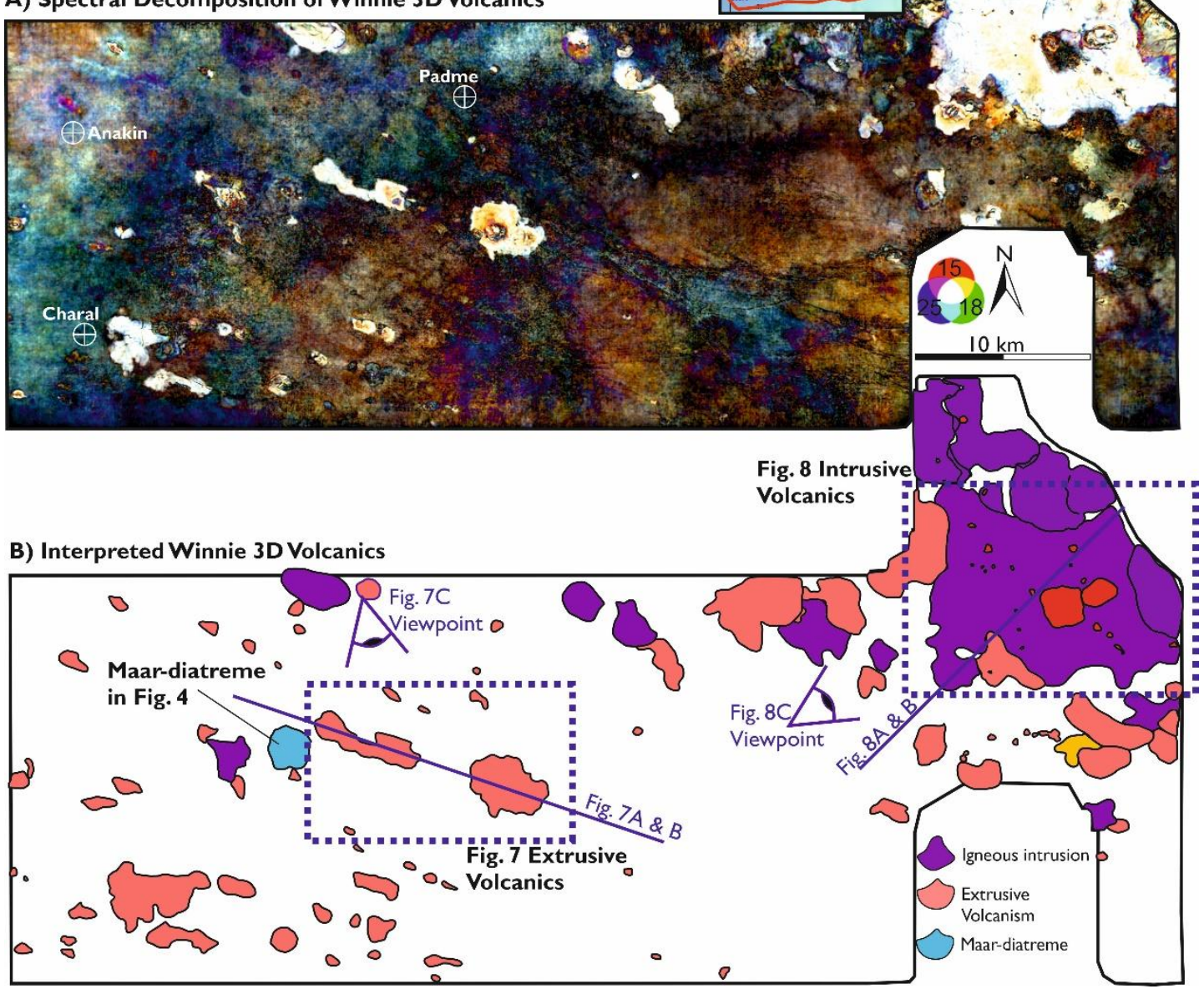

Figure 7. Spectral decomposition of a horizon mapped across the volcanics of the Winnie 3D survey. A Uninterpreted spectral decomposition. B Interpreted spectral decomposition highlight extrusive volcanics and the location of igneous intrusions. Note the increased number of intrusions towards the north east of the Winnie 3D survey. 

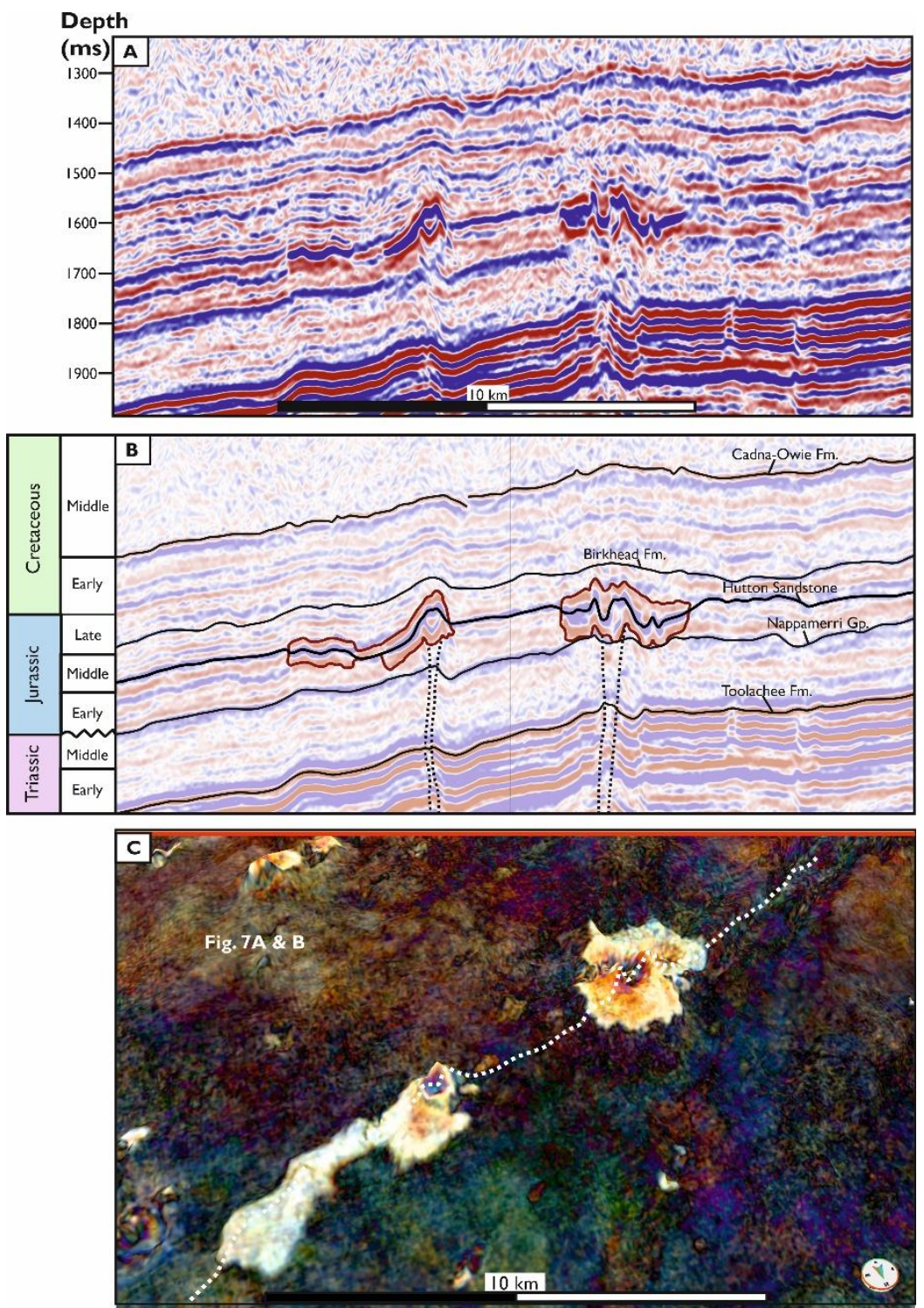

Figure 8. 3D Seismic across two monogenetic vents that extend into surface flows, from the Winnie 3D survey. A Uninterpreted line across the vents. B Interpreted line across the vents. Note the vertical zone of disrupted seismic directly below the vents, indicative of underlying plumbing system that fed the flows. C Spectral decomposition of a horizon mapped across the vents, 1227 highlighting their 3D morphology. 


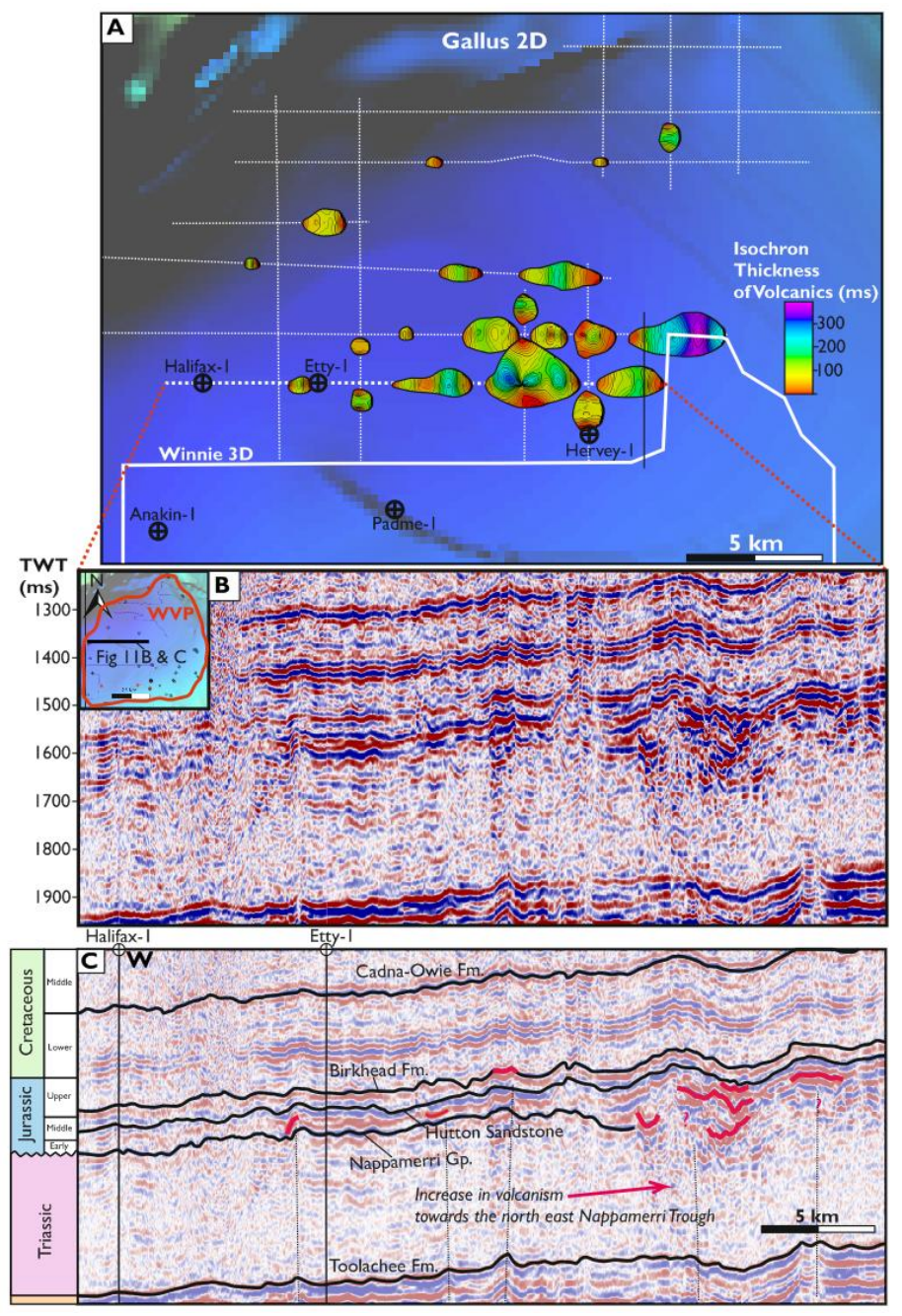

Figure 9. Seismic images of the Gallus 2D survey. A Isochron thickness map of the volcanics identified throughout the Gallus 2D survey. B Uninterpreted seismic line from the Gallus 2D survey. C Interpreted seismic line from the Gallus 2D survey. An increase in the volume of volcanics towards the east of the survey is apparent. 
1

2

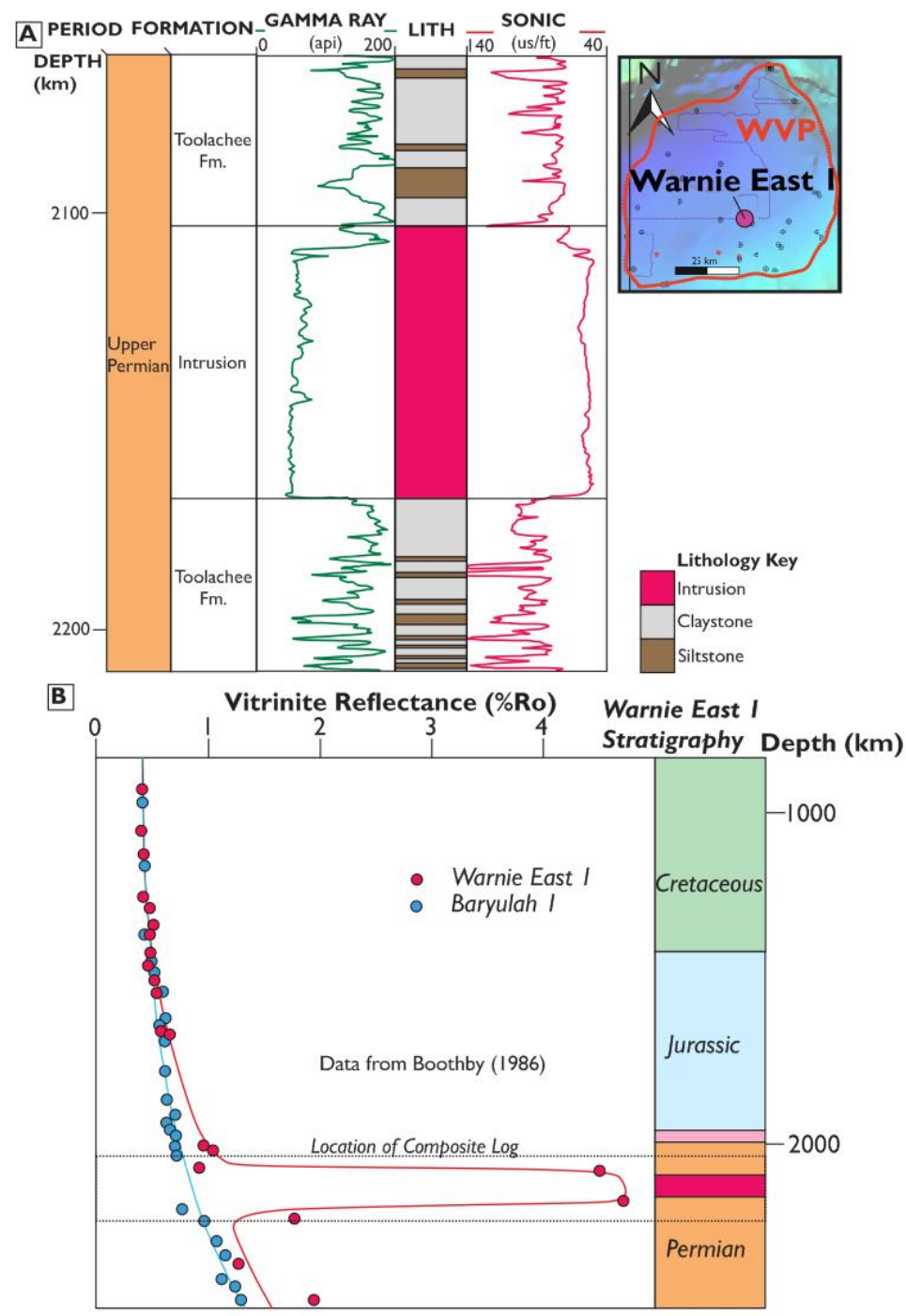

Figure 10. Well data for intrusive volcanic rocks within the Warnie East I well. A Composite log across the intrusion in the Warnie East well. B Vitrinite reflectance profile across the intrusion in the Warnie East well taken from Boothby (1986). Thermal effect both above and below the well is noted. 

Warnie East I

Warnie East I

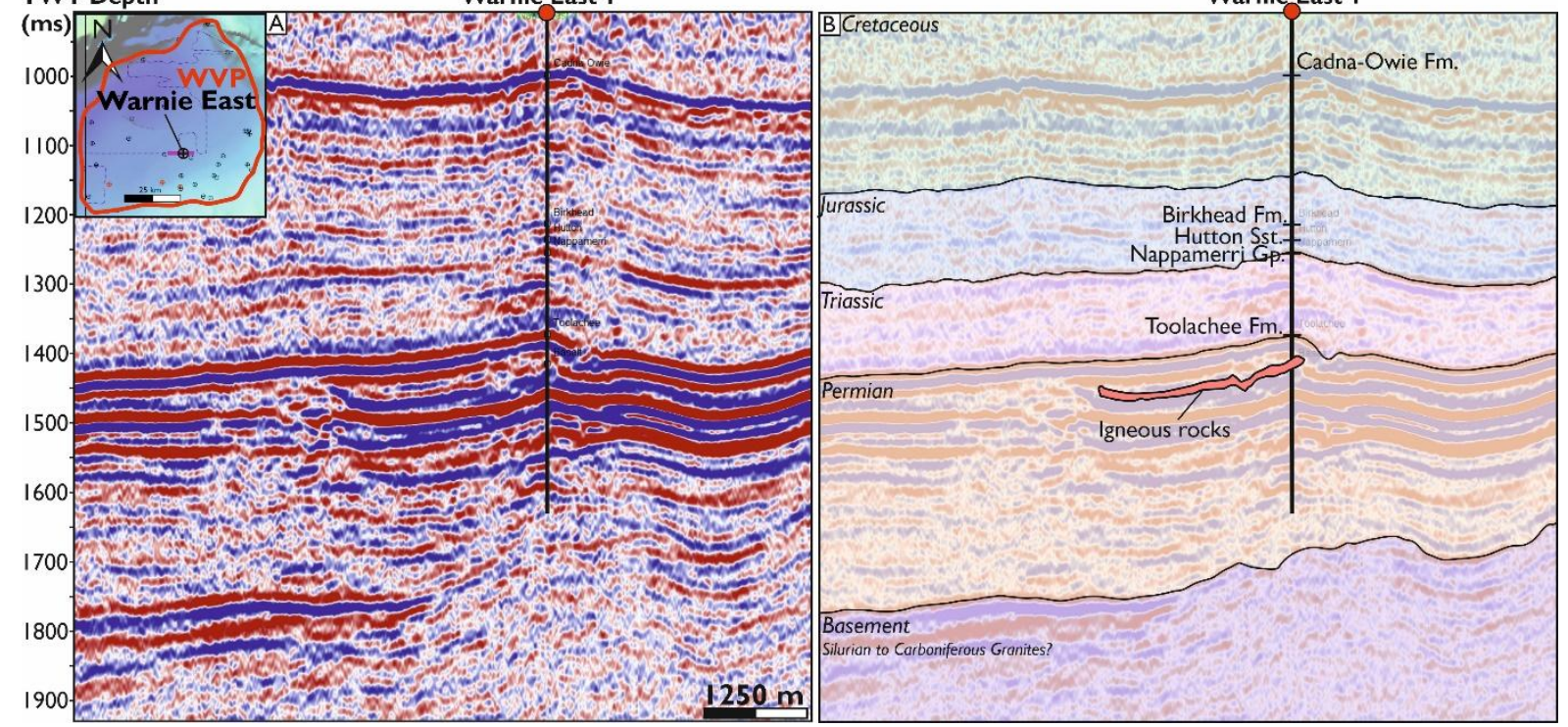

Figure II. 2D seismic line running from west to east across the Warnie East I well. The exact location of the igneous rocks is unclear on the line, however, a shallow saucer-shaped reflection with the Toolachee Fm. intersects Warnie East I at the depth igneous rocks are found. The lack of clearly imaged igneous rocks could point to more unimaged intrusive igneous rocks within the Cooper Basin succession. 


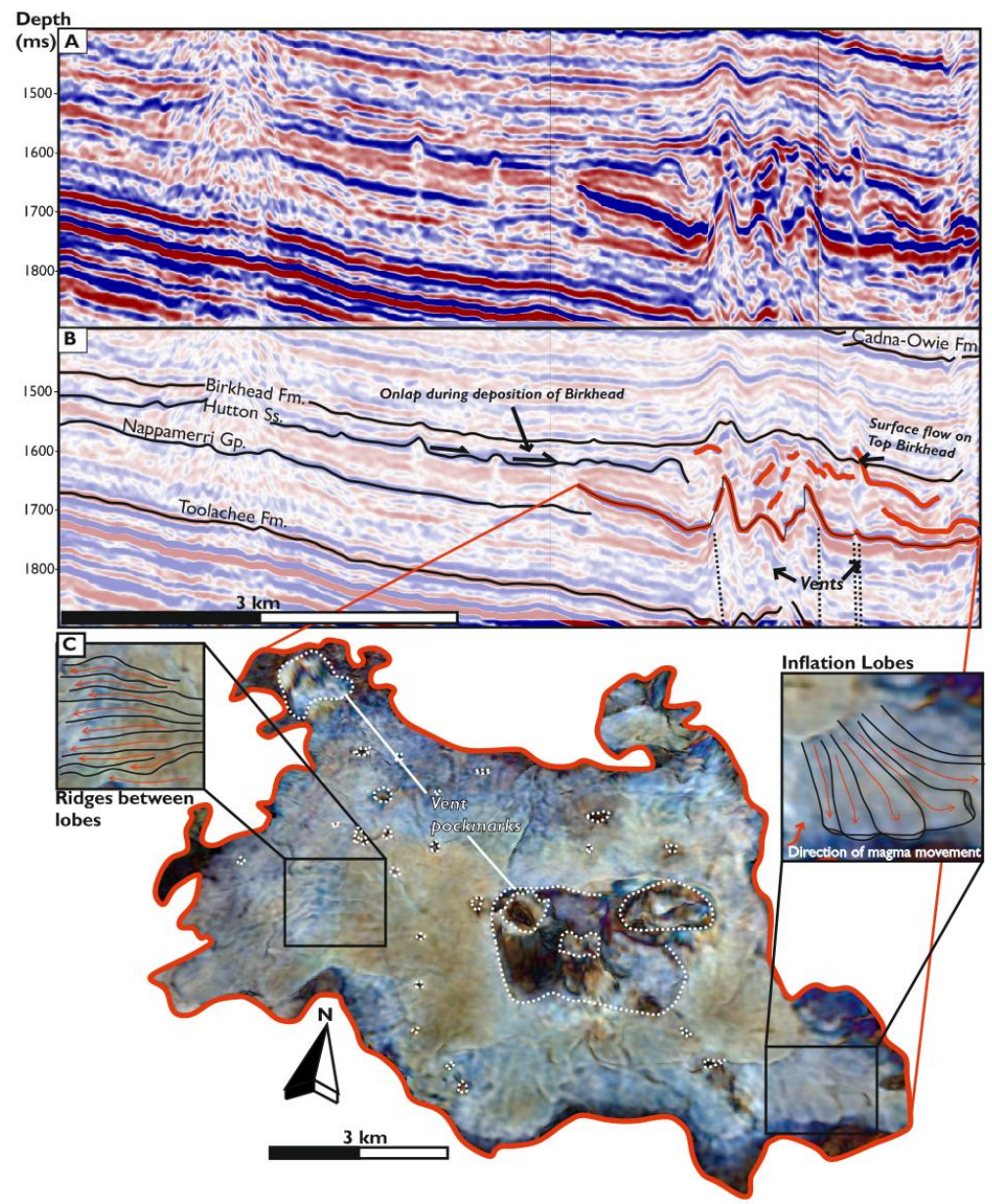

Figure 12. Seismic across the large intrusion in the Winnie 3D survey. A Uninterpreted seismic line. B Interpreted seismic line, illustrating the uplift of the overburden and the numerous vents and overlying volcanics associated with the intrusion. C Spectral decomposition of the intrusion, highlight the pockmarks of vents that pass through the intrusion and morphological characteristics associated with the intrusion. 
1

2 3

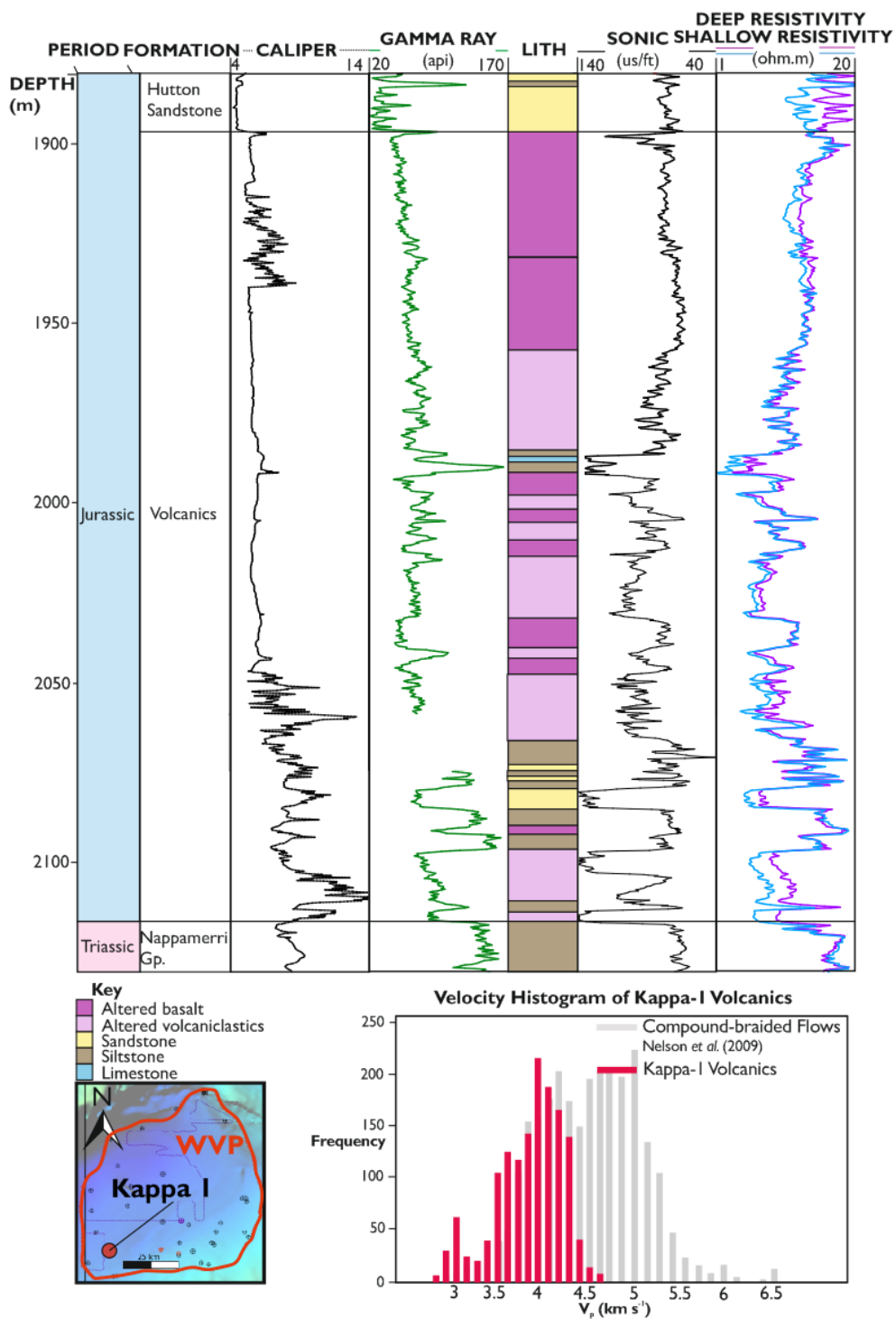

Figure 13. Well data for the Kappa-I well. A Composite log for the Kappa-I well volcanics. B Velocity histogram for the Kappa-I well volcanics, superimposed on top of Nelson et al.'s (2009) velocity histogram for compound-braided volcanics. 


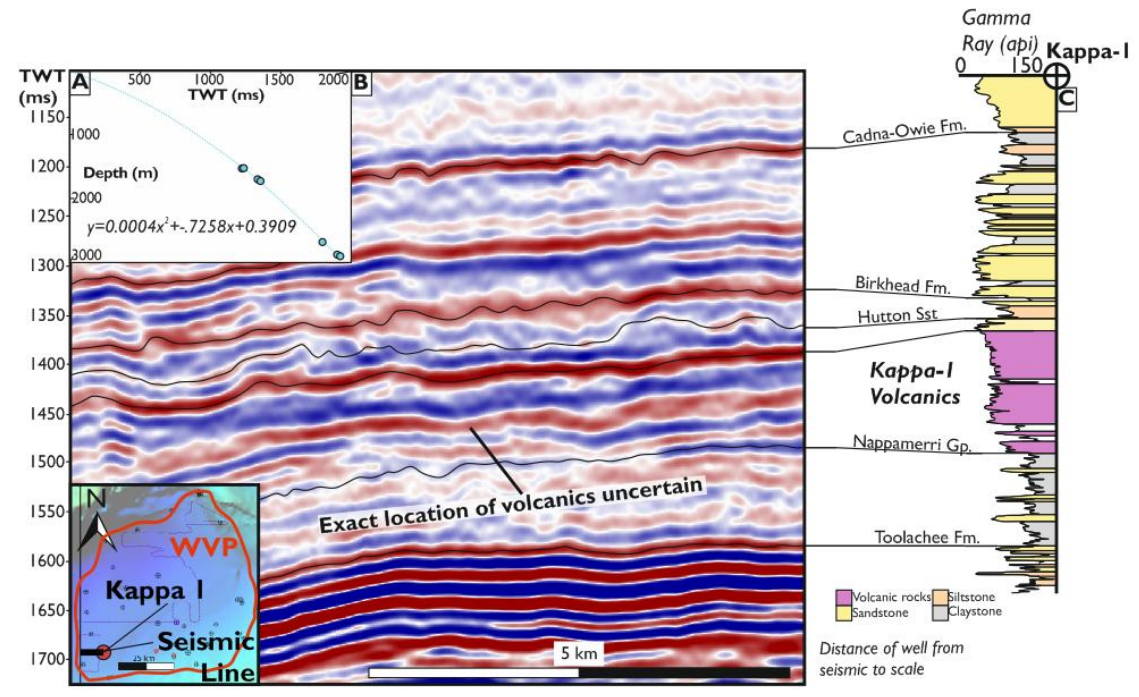

Figure 14. Position of the Kappa-I well in relation to the Snowball 3D survey. A Pseudo TWT/depth plot that was created using the velocity data synthesised for the wells drilled within the central Nappamerri Trough (namely Halifax, Etty, Anakin, Padme, Charal). This TWT to depth relationship was used to convert the Kappa-I well data from depth to time in order to display it adjacent to the Snowball 3D survey. B Line across the Snowball 3D survey with the position of formation tops based on the Kappa-I well displayed. C Gamma ray curve from the Kappa-I well with formation tops marked. 

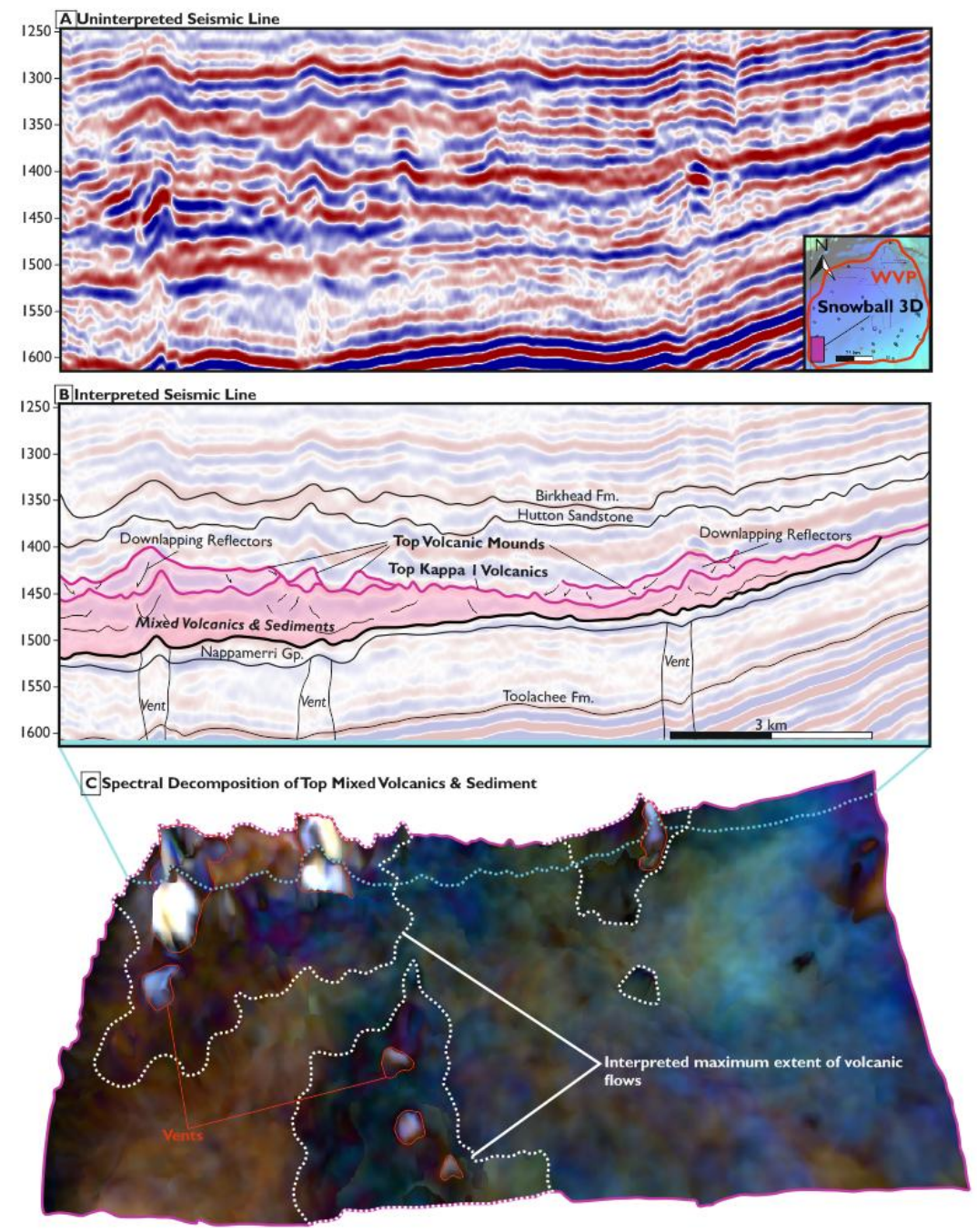

Figure I5. Seismic across volcanics within the Snowball 3D survey. A Uninterpreted seismic line. B Interpreted seismic line. Thick package of mixed volcanics \& sediments based off of the Kappa-I well volcanics. C Spectral decomposition of the top mixed volcanics \& sediment horizon. Location of vents noted by bright white colour with interpreted flow fields based on the cohesive dark colours extending away from the vents. 

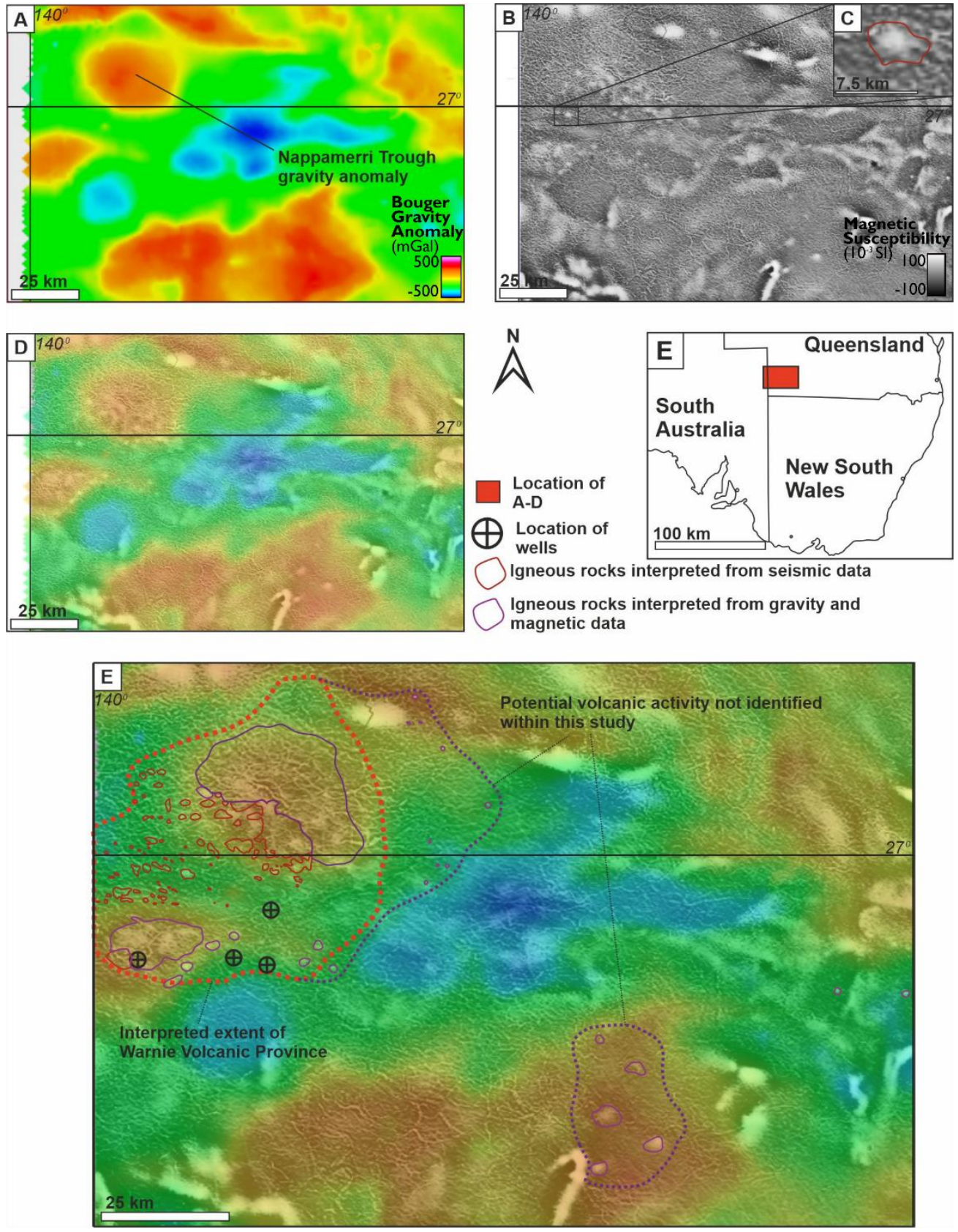

Figure 16. Regional geophysical surveys adopted from the Queensland Government's data repository. A Uninterpreted gravity anomaly with the location of the Nappamerri Trough Gravity anomaly highlighted. B Uninterpreted IVD magnetic data. C Inset of B showing a $\sim 6 \times 5 \mathrm{~km}$ gravity magnetic anomaly with the interpreted extent of igneous rocks identified using seismic data superimposed on top of the anomaly. D Uninterpreted image of the gravity data set to $50 \%$ transparency overlain on top of the IVD magnetic data. E Interpreted image of the combined gravity/IVD magnetic data. The extent of the Warnie Volcanic Province interpreted using well and seismic data within this study is indicated. Areas with circular magnetic anomalies and high gravity signatures not identified using well or seismic data are also highlighted. These areas could represent further igneous rocks within the SW Queensland. 


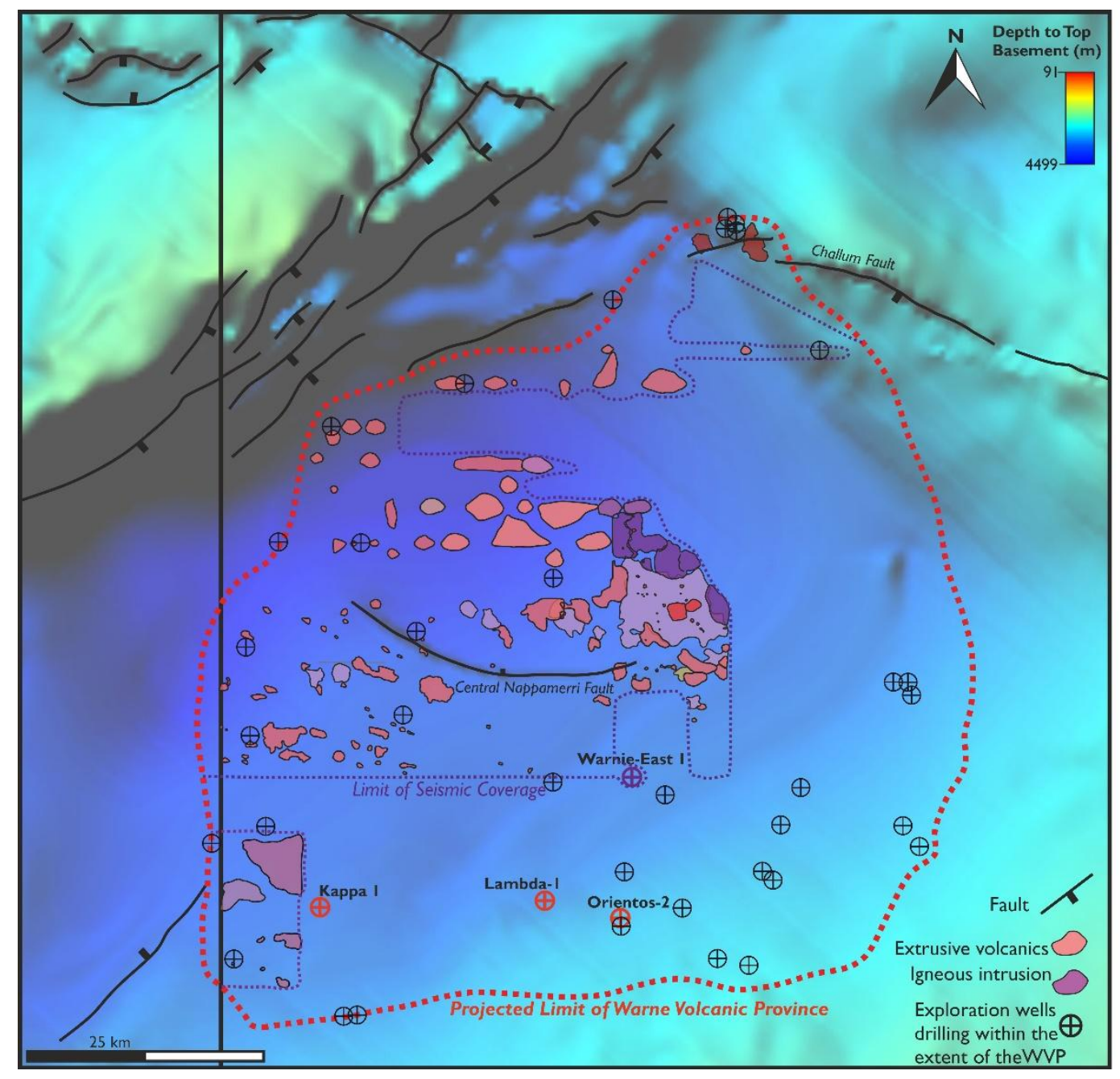

Figure 20: Regional map of the Warnie Volcanic Province. Depth to top basement map adapted from SA Department for Manufacturing, Innovation, Trade, Resources and Energy (2003). Location of extrusive volcanics and igneous intrusions based on seismic data. The igneous rocks, however, are thought to extend beyond the limit of seismic coverage towards the projected limit of the Warnie Volcanic Province. 
A) Location of Vents Intersecting Top Toolachee Reflection
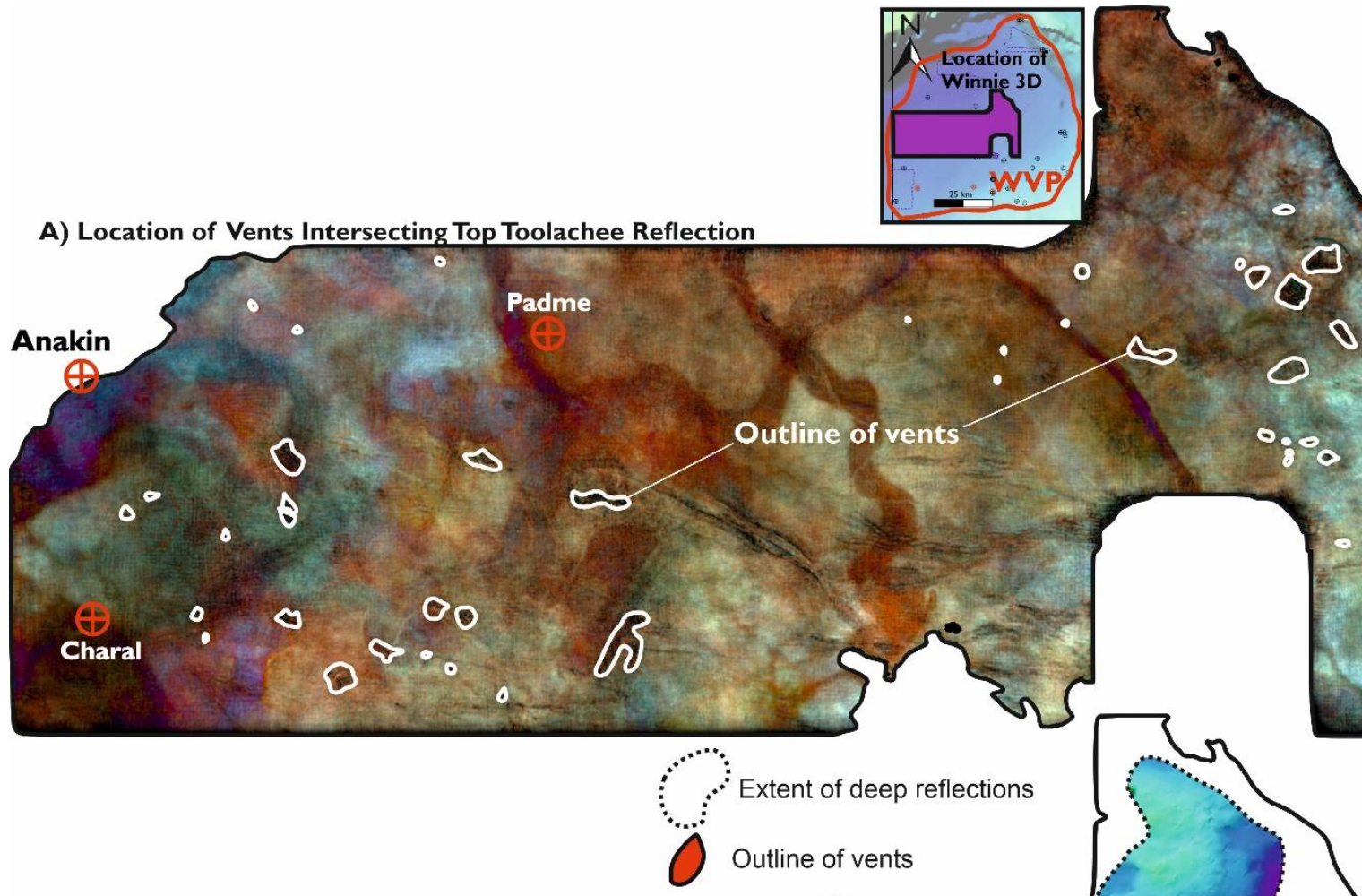

B) Location of Vents Relative to Deep Reflections

$10 \mathrm{~km}$

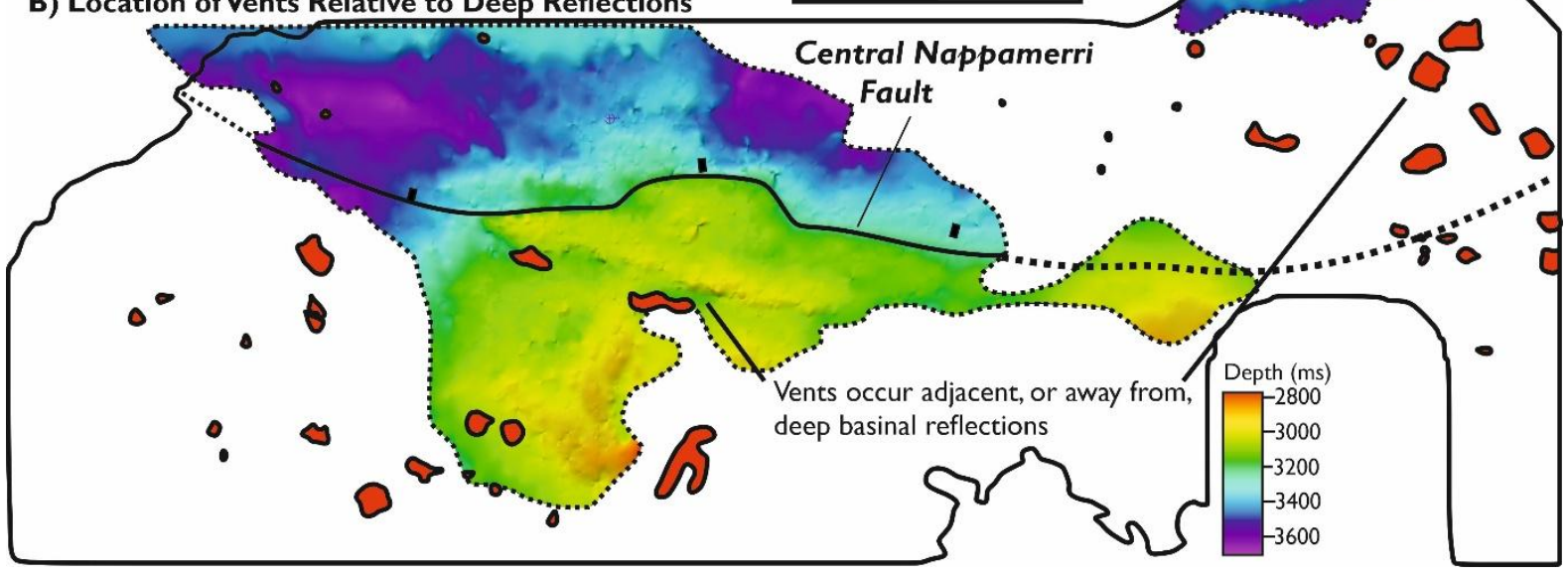

Figure 17. The basement structure and it's relation to vents within the Winnie 3D survey. A Spectral decomposition of the Top Toolachee horizon, highlighting the location of vents underlying the WVP. B Location of vents mapped using the Top Toolachee horizon superimposed on a TWT map of the top basement horizon. Many of the vents sit away from shallow basement reflections. Two vents are situated directly above the Central Nappamerri Fault. 

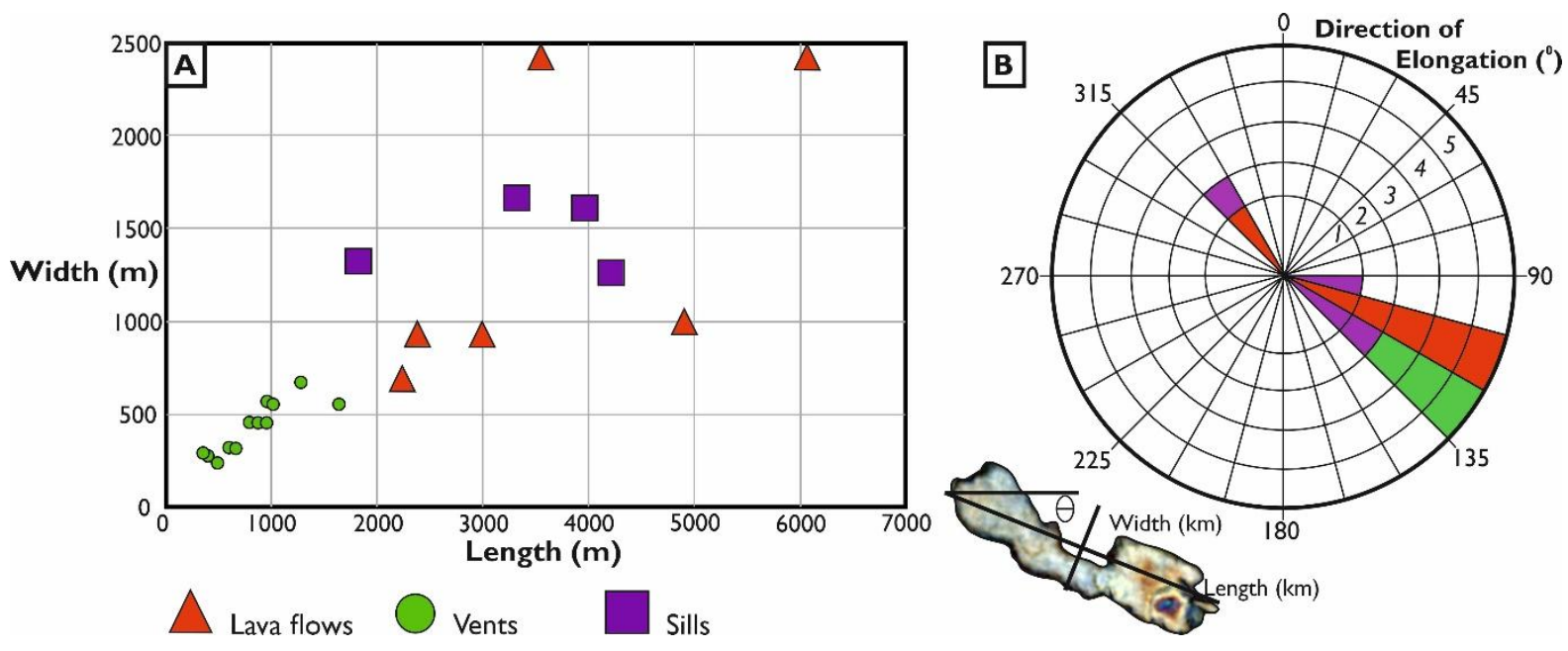

Figure 18: Size and orientation of volcanics within the Winnie 3D and Madigan 3D surveys. A Size of vents, intrusions and volcanic flows. Note, the large Winnie 3D intrusion has not been included on this figure due to its sheer scale (dimensions of $8 \mathrm{~km} \times 14 \mathrm{~km}$ ) compared to the rest of the Warnie Volcanic Province. B Direction of elongation for the igneous rocks, highlighting that they are elongate in a SE-NW direction. 


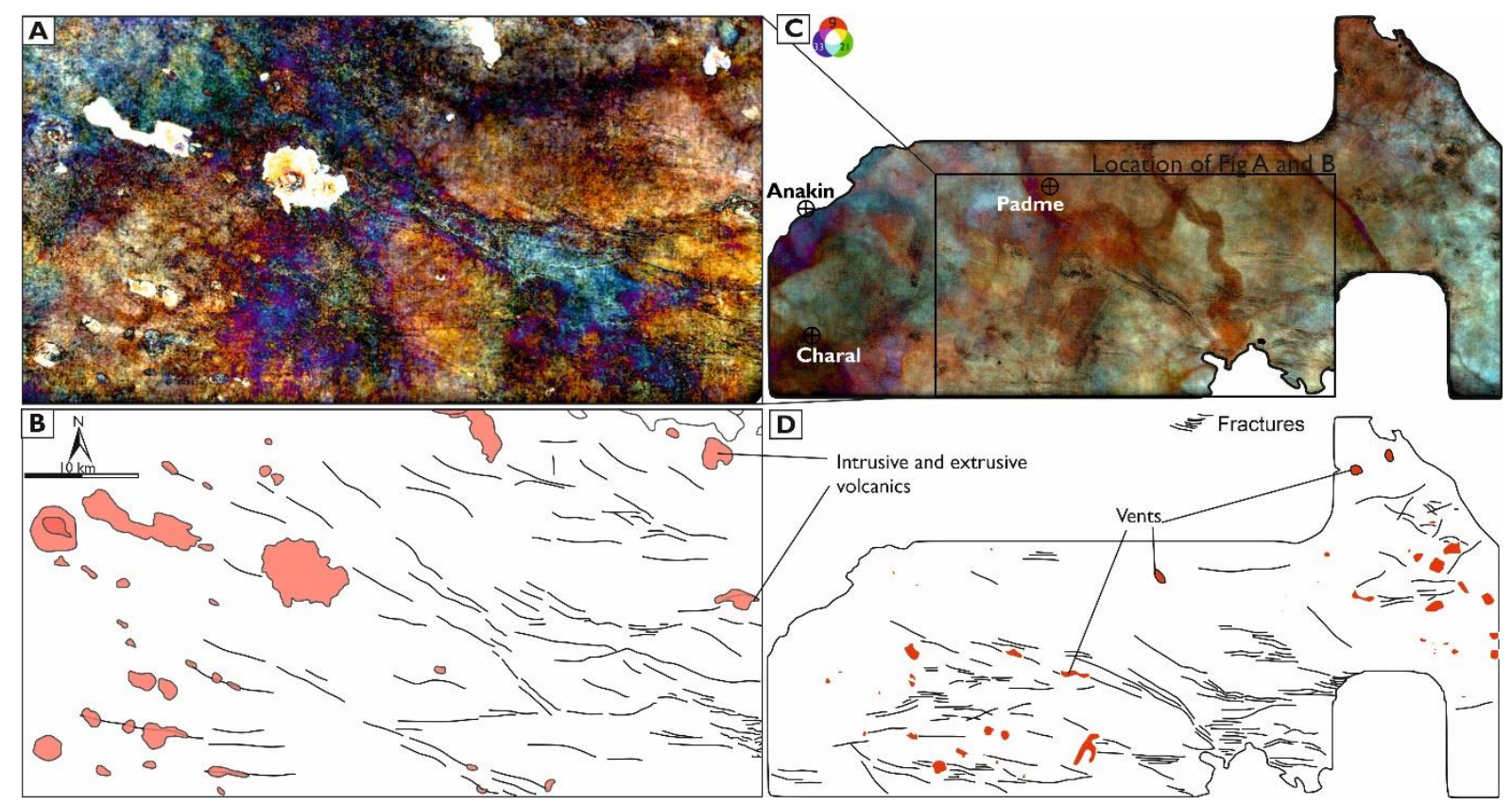

Figure 19: Mapping of faults within the Nappamerri trough. A Spectral decomposition of the Top Volcanics horizon from the Winnie 3D survey. B Interpretation of A with faults and the location of volcanics highlighted. C Spectral decomposition of the Top Toolachee horizon. D Interpretation of discontinuities within the Toolachee Horizon and the location of volcanics highlighted. 

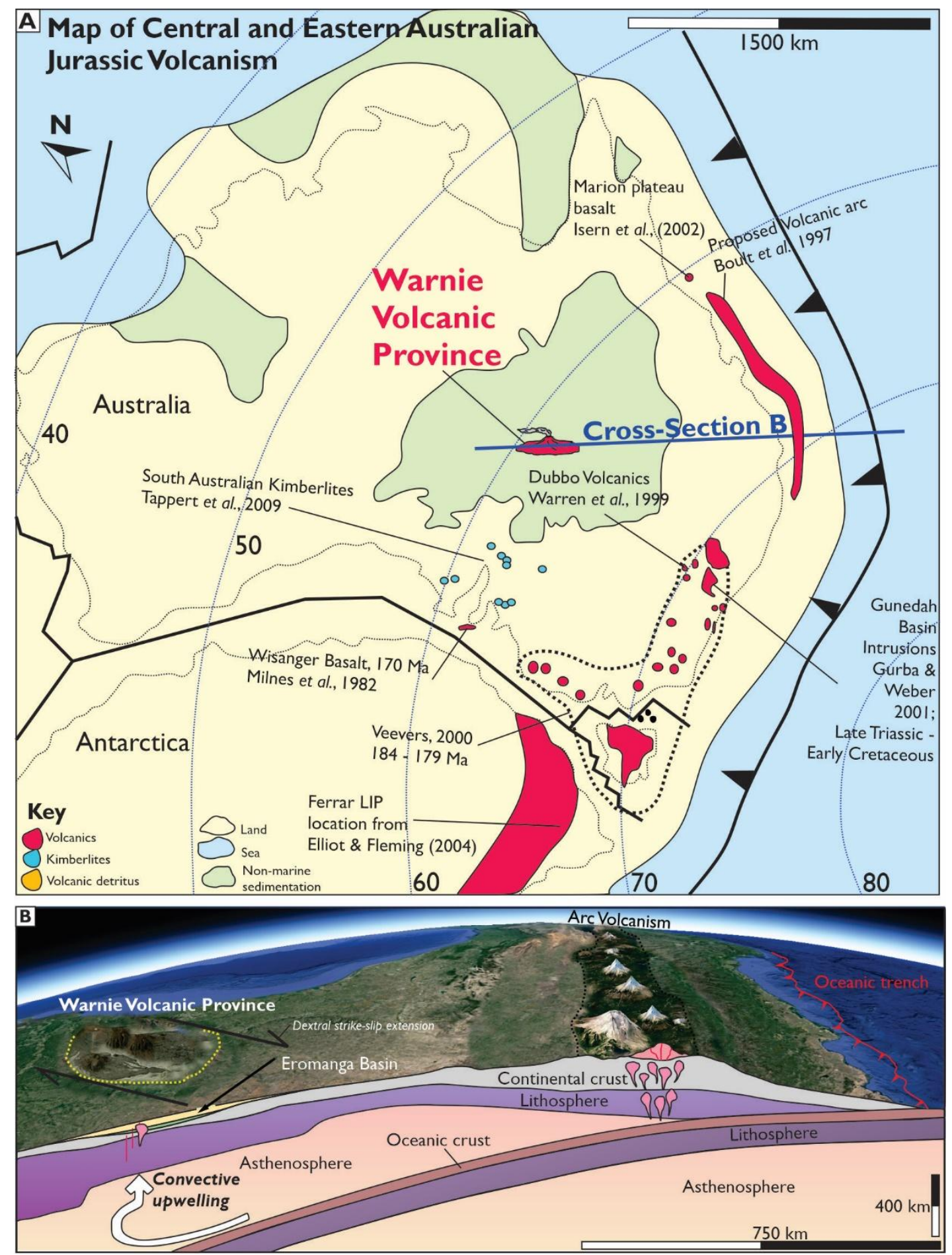

Figure 21: A Palaeogeographic map of Australia in the middle Jurassic (Oxfordian, I60 Ma), superimposed with the location of middle to late Jurassic volcanics in eastern Australia, described in the text. B Oblique view of Australia, highlighting the subducting pacific slab and associated convective upwelling. Steps in lithospheric thickness have adapted from Fishwick et al., (2008). 


\title{
The Warnie Volcanic Province: A Jurassic Voleanic ProvinceJurassic Intraplate Volcanism in Central Australia
}

\begin{abstract}
The Cooper and Eromanga Basins of South Australia and Queensland are the largest onshore hydrocarbon producing region in Australia. Igneous rocks have been documented infrequently within end of well reports over the past 34 years, with a late Triassic to Jurassic age determined from well data. However, the areal extent and nature of these basaltic rocks were largely unclear. Here, we integrate seismic, well, gravity, and magnetic data to clarify the extent and character of igneous rocks preserved within Eromanga Basin stratigraphy overlying the Nappamerri Trough of the Cooper Basin. We recognise mafic monogenetic volcanoes that extend into tabular basalt lava flows, igneous intrusions and, more locally, hydrothermally altered compound lava flows. The volcanic province covers $\sim 7500 \mathrm{~km}^{2}$ and is proposed to have been active between $\sim 180$ - $160 \mathrm{Ma}$. We term this Jurassic volcanic province the Warnie Volcanic Province (WVP) after the Warnie East I exploration well, drilled in 1985. The distribution of extrusive and intrusive igneous rocks is primarily controlled by basement structure, with extrusive and intrusive igneous rocks elongate in a NW-SE direction. Finally, we detail how the WVP fits into the record of Jurassic volcanism in eastern Australia. The WVP is interpreted as a product of extension and intraplate convective upwelling above the subducting Pacific Slab. The discovery of the WVP raises the possibility of other, yet unidentified, volcanic provinces worldwide.
\end{abstract}

\section{Keywords}

Intraplate; volcanism; monogenetic; Australia; Jurassic

\section{Introduction}

Igneous rocks are frequently recognised within sedimentary basins globally, within which their chronostratigraphic record can provide insights into the tectonic evolution of a region (Jerram \& Widdowson, 2005). Although extensive reworked volcaniclastic deposits are documented throughout Central Australia during the Mesozoic (Boult et al., 1998; Barham et al., 2016; Wainman et al., 20198), synchronous volcanic activity is infrequently documented within the sedimentary basins of Central Australia (Allen, 1998). The Cooper and the overlying Eromanga Basin extend for $130,000 \mathrm{~km}^{2}$ and $1,000,000 \mathrm{~km}^{2}$ respectively 
across central, north and eastern Australia. Together, they represent the largest conventional onshore hydrocarbon-producing region in Australia (Hall et al., 2016). The first gas discovery was made in 1963 and since then, over I,400 producing wells have been drilled, with 190 gas and II5 oil fields discovered throughout both basins (Fig. I) (Mackie, 2015). The majority of discoveries within the Cooper Basin are situated within structural traps on regional highs, however, a number of companies began to pursue unconventional hydrocarbon plays within the basin during the late 2000s, resulting in an increase in activity within the Nappamerri Trough (Hillis et al., 200I; Pitkin et al., 20I2; Khair et al., 20I3; Scott et al., 2013; Hall et al., 2016). The Nappamerri Trough is the largest and deepest depocentre within the Cooper Basin covering $\sim 10,000 \mathrm{~km}^{2}$ and reaching present day depths of $\sim 4.5 \mathrm{~km}$ (Fig. IA). The acquisition of new well and seismic data due to renewed exploration activity has resulted in the increased recognition of igneous rocks in the Cooper and Eromanga Basins.

Igneous rocks of suspected late Triassic-Jurassic age have been sporadically encountered by drilling during the past 34 years (Short, 1984; Boothby, 1986; Bucknill, 1990; Allen, 1998), though there has been no systematic study of the character, origin and significance of these igneous rocks. Here, we combine extensive seismic, well and airborne geophysical data to document the extent and character of Mesozoic igneous rocks recognised within Eromanga Basin stratigraphy overlying the Nappamerri Trough of Cooper Basin age. The Warnie Volcanic Province (WVP) is the suggested name for this $>7,500 \mathrm{~km}^{2}$ suite of igneous rocks (Fig. IB). The province is named after the Warnie East I exploration well, which was drilled in 1985 and encountered $65 \mathrm{~m}$ of basalt. We provide an in-depth study of the regional implications of the WVP for the Cooper and Eromanga Basins. We find that SE-NW striking intracratonic sag faulting controlled the morphology of igneous rocks whilst the basin structure likely controlled the location of igneous rocks.

Finally, we discuss the origin of the WVP. Evidence for Triassic to mid-Cretaceous volcanic activity is pervasive throughout the sedimentary basins of central Australia, manifested by an influx of volcanic arc-derived sediment into the Eromanga Basin (Boult et al., 1998), silicic tuffs in the Surat Basin (Wainman et al., 2015) and widespread volcanogenic zircons throughout the Great Artesian Basin (Bryan et al., 1997). However, the source of volcanic activity and, furthermore, the origin of intraplate volcanism can be contentious (Conrad et al., 20II; Zhou et al., 2018). We consider the source of the WVP and the tectonic implications for central Australia. We theorise that the WVP's geodynamic origin is 
ultimately linked to subduction at the eastern margin of Gondwana, through asthenospheric shear $1500 \mathrm{~km}$ from the oceanic trench, however, we also discuss other mechanisms that can produce intraplate volcanism. Our discovery of a previously undescribed volcanic province in an area that has undergone $>50$ years of extensive subsurface data collection due to continued hydrocarbon exploration, raises the prospect of other undiscovered intraplate volcanic provinces both in Australia and in other continental areas worldwide.

\section{Geological Overview of the Cooper and Eromanga Basins}

The geology of southwest Queensland and northeast South Australia, central Australia, is defined by a series of intracratonic basins stacked on top of each other; the Warburton, Cooper, Eromanga and Lake Eyre Basins (Fig. 2 \& Fig. 3).

The Warburton Basin is a lower Palaeozoic sedimentary basin that hosted Silurian to Carboniferous granite emplacement (Murray, 1986; Meixner et al., 2000; Boucher, 1997). The Cooper Basin unconformably overlies the Warburton Basin. The Cooper Basin is a northeast to southwest trending intracratonic structural depression that accommodated the deposition of sedimentary rocks from the late Carboniferous to the Middle Triassic (Gravestock et al., 1998). Several tectonic origins for the Cooper Basin have been suggested, including a mildly compressional structural depression (Apak et al., 1997; Sun, 1997), a depression created through wrenching (Kuang, 1985) and extension during postcompression flexural relaxation (Kulikowski et al., 2015). Deposition throughout the early Permian was dominated by highly sinuous fluvial systems situated on a major floodplain with peat rich swamps and lakes (Khair et al., 2015). Later Triassic deposition took place in a period of tectonic quiescence (Gravestock et al., 1998).

Deposition in the Cooper Basin was terminated by regional uplift, compressional folding and erosion in the middle Triassic. The Cooper Basin is unconformably overlain by the Eromanga Basin, which forms part of the Great Artesian Superbasin, a group of interconnected basins that cover much of Queensland, South Australia and New South Wales. The Eromanga Basin is an intracratonic sag basin whose subsidence has been attributed to dynamic topography induced by subduction of the pacific plate below Australia (Gallagher \& Lambeck, 1989; Russell \& Gurnis, 1994). 


\section{I The Jurassic Succession of the Eromanga Basin}

The Jurassic succession of the Eromanga Basin is of stratigraphic importance as it is where the extrusive igneous rocks documented within this study are believed to be located. Much of the Jurassic strata in the Eromanga Basin consists of predominantly quartzose fluviatile sandstones with subordinate shales and some coals (Burger \& Senior et al., 1979; Exon \& Burger, 198I; Draper 2002). Sediments in the Eromanga Basin can be divided into three packages of decreasing age; lower non-marine, marine and upper non-marine. The focus of this study is the lower non-marine package that was deposited between the early Jurassic $(\sim 200 \mathrm{Ma})$ and the early Cretaceous $(\sim 155 \mathrm{Ma})$, within which the extrusive volcanics of the WVP are recognised (Fig. 2). During this time, large sand-dominated, braided fluvial systems drained into lowland lakes and swamps. Throughout deposition, it is believed that sediment supply was a competing product of input from arc volcanism to the east, and sediment sourced from stable cratonic regions to the south (Boult et al., 1997). In the next part of this paper we briefly detail the Early to Late Jurassic stratigraphy in order to provide a palaeogeographic framework for the study. The stratigraphic framework of the Jurassic succession has been iterated on considerably in the last 20 years, evidenced by the progression of Alexander \& Hibburt's stratigraphic ages (1996) to Reid et al.'s (2009), to those listed on the Australian Stratigraphic Units Database.

\section{I.I Poolowanna Formation, Early Jurassic, $200-178 \mathrm{Ma}$}

In southwest Queensland, the Poolowanna Fm. sits unconformably on top of the Late Triassic unconformity, which formed as a result of uplifting, tilting, and erosion of the Cooper Basin at the end of the Early to Middle Triassic (Fig. 2). Lithologies consist of coal and silt deposited in a highly sinuous fluvial setting with minor coal swamps (Hall et al., 2016).

\section{I.2 Hutton Sandstone, Early to Middle Jurassic, I 78-I 66 Ma}

The Hutton Sandstone is a high energy braided fluvial Jurassic sandstone that either sits conformably on top of the Poolowanna Fm. or, where the Poolowanna is not present, unconformably above Triassic sediments (Kapel, 1966; Watts, 1987). 


\section{I.3 Birkhead Formation, Middle to Upper Jurassic, 166-160 Ma}

124 The boundary between the Hutton and Birkhead formations is sharp to transitional across the Eromanga Basin (Lanzilli, 1999) and is associated with a change in the depositional setting from the high energy, braided fluvial setting of the Hutton Sandstone to a low energy, fluvial-deltaic to lacustrine setting in the Birkhead Formation (Watts, 1987; Lanzilli, 1999). This decrease in depositional energy is also associated with a change in sediment provenance from craton-derived sediment to lithic-rich, volcanogenic sediment from a proposed volcanic arc situated to the east above the subducting Pacific plate (Lanzilli, 1999).

The diachronous influx of volcanogenic sediments can be traced across the Eromanga Basin (Boult et al., 1997). There are several key features associated with the sediments shed from the volcanic arc (Paton, 1986):

- $50 \%$ quartz with high amounts of potassium and plagioclase feldspar. Trace amounts of tourmaline, pyroxene, mica and zircon are also present (Watts, 1987).

- Common altering of the above lithics to kaolinite and chlorite or replacement of carbonate cements such as siderite or dolomite.

- Rare glassy fragments.

Based on the lithology of the volcanogenic sediments, it has been concluded that the volcanics that formed them were of acid to intermediate affinity (Paton, 1986).

\section{I.4 Adori Sandstone, Upper Jurassic, 160-155 Ma}

The Birkhead Formation is capped by the Adori Sandstone, marked by a transition to clean, non-volcanogenic sedimentation. The Adori Sandstone is a well sorted and typically cross bedded, fine to coarse-grained sandstone deposited in a low sinuosity fluvial system consisting of channel, point bar and flood plain deposits in the Central Eromanga Basin (Burger \& Senior, 1979; Alexander \& Hibburt, 1996).

\subsection{Structural Setting of the Study Area}

Structurally, the Cooper Basin can be divided into southern and northern sections (Gravestock et al., 1998; Hall et al., 2016). To the north, depocentres are dominantly Triassic, with Permian depocentres in the south (Hall et al., 2018). The northern and southern sections of the Cooper Basin are separated by the Jackson-Naccowlah-Pepita Trend (JNP trend) (Fig. I). In the south west, depocentres are generally thicker, reaching a 
maximum thickness of $2400 \mathrm{~m}$ in the Nappamerri Trough (Hall et al., 2016) and many of these depocentres have experienced synclinal folding due to differential compaction (Apak et al., 1997). The major depocentres are separated by northeast-southwest trending ridges (Gravestock et al., 1998).

157 The area of focus in this study is the eastern Nappamerri Trough of north east South 158 Australia and south west Queensland. The Nappamerri Trough contains the deepest 159 basement within the Cooper Basin and hosts the Halifax well that intersected the deepest Permian-age sedimentary rocks in the basin at $4,209 \mathrm{~m}$. To the north, the Nappamerri Trough is bounded by the Gidgealpa, Canway, Packsaddle and Innamincka ridges (Fig. IA). The southern extent of the Nappamerri Trough is bounded by the Della-Nappacoongee, Dunoon and Murteree ridges (Fig. I) (Hall et al., 20I6).

\section{Methodology}

\section{I Identification of Volcanics Using Subsurface Data}

Here we describe the main techniques that were used to investigate igneous rocks within the Nappamerri Trough.

\section{I.I Seismic Data}

Seismic reflection data has been shown by numerous studies to be especially effective at imaging igneous rocks due to the high acoustic impedance of igneous material when compared to surrounding sedimentary rocks and the distinctive morphology of lava flows and intrusions (Planke et al., 2000). Here we provide a brief introduction to the different types of igneous rock identified in the subsurface on seismic reflection data.

Vents identified within seismic reflection data are typically grouped into either hydrothermal or volcanic vents (Reynolds et al., 2017). The morphologies of hydrothermal vents and volcanoes are similar as they both exhibit eye, dome or crater shaped morphologies in seismic data (Fig. 4)(Planke et al., 2005; Reynolds et al., 2017). This can make distinguishing hydrothermal vents from volcanoes difficult when seismic reflection data are the sole data source.

Volcanoes can be confidently identified using seismic reflection data where they extend into lava flows (e.g. Fig. 4A-D). Lava flows are distinguishable as layer-parallel acoustically hard, 
bright reflectors within the subsurface (Planke et al., 2000; Schofield \& Jolley, 2013; Hardman et al., 2019) (Fig. 4B). Extrusive igneous rocks are distinguishable from intrusive igneous rocks as they do not transgress stratigraphy.

Igneous intrusions have been studied intensely using 3D seismic data (Bell \& Butcher, 2002; Thomson \& Schofield, 2008; Archer et al., 2005; Magee et al., 20I4). Igneous intrusions form acoustically hard, bright reflectors that are layer parallel or transect stratigraphy. In places, they can produce forced folding of the overburden with onlapping stratigraphy facilitating age-dating of the intrusion (Trude et al., 2003).

\section{I.2 Seismic Attributes}

3D seismic reflection data facilitates the analysis of the geophysical properties of igneous rocks in 3D. Seismic attributes such as RMS amplitude and spectral decomposition have proven to be effective tools in picking the extent and morphology of lava flows in seismic data (Figs. 4C \& G) (Schofield \& Jolley, 2013; Planke et al., 2017; Hardman et al., 2019). Spectral decomposition involves filtering 3D seismic reflection wavelets to produce three amplitude components at distinct frequencies that are displayed as separate colour channels using the primary colours red, green and blue. These channels are then blended to produce full colour spectrum images where the igneous rocks appear visibly different to the surrounding sediments, due to their differing reflectiveness for particular frequencies (they transmit acoustic energy efficiently at all frequencies). Furthermore, this technique can be used to investigate the geometries of igneous rocks and features such as inflation lobes can help with distinguishing igneous intrusions from extrusive igneous rocks.

\section{I.3 Well Data}

In addition to the use of seismic data, the integrated analysis of borehole data including wireline log responses, core and cuttings is essential in accurately identifying igneous rocks within the subsurface (Nelson et al., 2009; Rider \& Kennedy, 20I I; Watson et al., 2017). The onshore response of igneous rocks in outcrop has been linked to offshore observations facilitating the identification of different volcanic facies through petrophysical and petrological analysis (Nelson et al., 2009; Millet et al., 2016).

210 Here, we use a combination of petrophysical and petrological data in our description of the 211 WVP. Although cuttings and core were not examined within this study, descriptions were 212 available within well reports that were integrated with petrophysical data and seismic 
213 reflection data to provide a comprehensive overview of the data available. It is important to recognise that the petrological descriptions taken from well reports is secondary information and, as such, variable in quality. Wherever petrological descriptions have been taken from end of well reports it is explicitly stated within the text with a reference to the relevant well report.

\subsection{Description of Dataset}

219 The Cooper and Eromanga Basins have been explored extensively over the past 60 years and are characterised by the largest collection of well and seismic reflection data for any onshore sedimentary basin in Australia. Over 2000 wells have been drilled in the Cooper and Eromanga Basins. Despite this, of the wells available, only 3 (Lambda I, Orientos 2 and Kappa I) were identified as having intersected extrusive volcanic rocks with only I well (Warnie East I) encountering an intrusive igneous rock. To estimate the relative age of the volcanic units, well data were tied, where possible, to the seismic reflection surveys available. For constraining the age of the Eromanga succession within the Central Nappamerri trough, the Halifax, Etty, Padme, Charal and Anakin wells represented key datasets (location on Fig. IC).

A large database of seismic reflection data was available through Santos Limited and the Queensland Government's Department of Natural Resources and Mines. 3D and 2D seismic reflection surveys throughout the South Australian and Queensland sides of the basin were assessed for the presence of igneous rocks (the extent of the seismic data examined is visible on Fig. IB). Notably, only four surveys available to this study (the Winnie 3D, the Gallus 2D, the Madigan 3D and the Snowball 3D survey (provided for use by Santos Limited)), were interpreted to contain igneous rocks and a summary of these surveys is provided in Table I. Furthermore, 3 individual 2D seismic lines were available across the Lambda I, Orientos 2 and Warnie East I wells. Seismic data were displayed using normal (American) polarity, whereby a downward increase in acoustic impedance corresponds to a positive (blue) reflection and a downward decrease a negative (red) reflection. The only exception to this is the Snowball 3D survey that was displayed such that a downward increase in acoustic impedance corresponds to a red, negative reflection (European polarity). Within the Jurassic succession the average dominant frequency within the seismic data was $\sim 40 \mathrm{~Hz}$, with volcanic rocks in the region having an acoustic velocity of 4 to $6 \mathrm{kms}^{-}$ 
244 ' (taken from the Lambda I exploration well). Using an average velocity of $5 \mathrm{kms}^{-1}$ a vertical resolution of $\sim 30 \mathrm{~m}$ and a detection limit of $4 \mathrm{~m}$ was calculated.

Here we present an overview of all the available datasets that constrain the distribution and age of igneous rocks within the study area. We recognise three distinct types of igneous rocks within this study:

- Extrusive igneous rocks

- Intrusive igneous rocks

- Altered extrusive igneous rocks

252 Each type is described in detail using the available well and seismic data before the regional character of the Warnie Volcanic Province as a whole is discussed using regional gravity and magnetic surveys. It is important we recognise that whilst this is the extent of the data that was available during this study, the authors are aware of other seismic reflection surveys within the Nappamerri Trough that were not available to download digitally and were not possible to acquire within the period of time during which this study was conducted. These surveys may also image igneous rocks that could fuel further work on the area.

\section{Description of Extrusive Igneous Rocks}

\section{I Well Data}

261 Unaltered, basaltic, extrusive igneous rocks are recognised in the Lambda I and Orientos 2 wells in the eastern Nappamerri Trough.

The Lambda I well was drilled in 1984 by Delhi Petroleum Pty. Ltd. At a depth of I570.9 m, $283 \mathrm{~m}$ igneous rocks were intersected, directly underlying the base of the Birkhead Fm. (Fig. 12). The upper $33 \mathrm{~m}$ of basalt are noted as heavily weathered, fractured and vesicular in the Lambda I well report (Short, 1984). The remaining $250 \mathrm{~m}$ of basalt is described as fresh and crystalline. It has low gamma ray values, with consistently high density and acoustic velocity (Fig. 12A). There are localised areas where the density drops drastically, however, these are associated with increases in the caliper and may therefore point to caving of the wellbore when it was drilled or fractures within the basalt, rather than lithological variations. At the base of the basalt $\sim 1.5 \mathrm{~m}$ of core was cut, within which the fine grained, crystalline nature of the basalt is apparent (Fig. 5A, see picture). 
273 Similarly to Lambda I, Orientos 2 drilled through igneous rocks situated at $1555 \mathrm{~m}$, beneath the Jurassic age Adori Sandstone (Fig. 14). The well drilled through $34 \mathrm{~m}$ of igneous rocks before drilling was ceased, prior to the well reaching the base of the igneous rocks. The igneous rocks are described as dark green, grey black with quartz inclusions and common amphiboles in the end of well report (Bucknill, 1990). Similar to the Lambda I well, Orientos 2 encountered a $14 \mathrm{~m}$ section of weathered basalt identifiable by low density and sonic values in the well logs, followed by a high density and high velocity section, matching the petrophysical response of the Lambda I igneous rocks. Draper (2002) noted that Orientos 2 was drilled $<1 \mathrm{~km}$ from Orientos I, which did not intersect basalt, suggesting that the basalt In Orientos 2 might be intrusive in origin. However, we note that Orientos I may have been drilled beyond the limit of the basalt and, as such, we do not take the absence of igneous rocks in Orientos I to be indicative of an intrusive origin for the Orientos 2 igneous rocks.

Nelson et al. (2009) provided compelling evidence for the use of binning velocity data in estimating the type of volcanic rock present. In order to investigate the extrusive or intrusive nature of the Lambda I igneous rocks, interval velocity histograms were created. They were then binned with a bin spacing of $0.125 \mathrm{~m}$ order to create a velocity histogram (Fig. I2C). These were superimposed on the velocity histogram fields of Nelson et al., (2009) that were obtained from boreholes on the Faroe Islands in the North Atlantic, in order to compare the acoustic velocities of igneous rocks in the Nappamerri Trough with values from extrusive igneous rocks in the Northwest Atlantic. It can be seen in Fig. $5 \mathrm{C}$ that the Lambda I volcanics show a very strong similarity to the tabular basalt analysed by Nelson et al. (2009).

Additionally, vitrinite reflectance data (Boothby, 1986) was recorded for sediments deposited on top of the Lambda-I volcanics (Fig. 5B). Notably, in the sediment contact with the volcanics, there is no deviation towards high \%RoMax, suggesting that the Lambda I volcanics had little thermal effect on the overlying organic matter. It has been observed in locations such as Namibia that the thermal effect of lava flows is restricted to $\ll<I \mathrm{~m}$ depth below lava contacts (Grove et al., 2017) whereas igneous intrusions have a much larger thermal effect on surrounding sediments due to their inability to release heat directly to the earth's surface (see Utgard Sill Complex, Aarnes et al., 2015). If this were an intrusion, it is expected that the VR values would be elevated (Stewart et al., 2005), and the absence of such elevated values implies that the basalt is extrusive. 


\subsection{Seismic Data}

Extrusive igneous rocks have been documented using the available seismic data. These observations will focus on the Winnie 3D survey as it is the largest, highest quality 3D dataset within which the full range of igneous rocks is observed. From there, we build out to the other seismic surveys utilised.

311 In a single 2D seismic line intersecting the Lambda I well the tabular basalt intersected by the well corresponds to a high amplitude reflection most pronounced at the location of the well but also continuing $\sim 3 \mathrm{~km}$ to the west of the survey (Fig. 6). The centre of the survey (and the location of the well) corresponds with a $\sim 1.5 \mathrm{~km}$ wide anticline that exhibits doming on the order of $\sim 150$ ms. Below the anticline and the location of the volcanics, the 2D seismic reflections are visibly distorted, being most pronounced beneath the location of the well where a velocity pull-up effect is visible.

Within the Winnie 3D survey, we identified $\sim 100,<=4 \mathrm{~km}^{2}$ cone shaped features that often express an eye-shaped morphology, doming and velocity pull-up effects similar to those observed in the location of the Lambda I well (Fig. 4B). The cones within the survey are less than $2 \mathrm{~km}$ long and $750 \mathrm{~m}$ wide, and often elongate in a NW-SE direction (Fig. 6). Due to the extrusive nature of the Lambda I well, their stratigraphic concordance and their cone shaped morphology in seismic, we have interpreted these as monogenetic volcanoes, small cumulative volume volcanic edifices built up by one continuous, or many discontinuous, small eruptions over a short time scale $(<=10$ years) (Németh \& Kereszturi, 20I5).

In the Winnie 3D survey, twelve of the volcanoes are linked with what appear to be elongate, NW-SE oriented lava flows that are conformable to stratigraphy and have dimensions of $2-7 \mathrm{~km}$ in length and $0.5-2.5 \mathrm{~km}$ in width (covering areas of $4-13.5 \mathrm{~km}^{2}$ ) (e.g. Figs. 7 \& 8).

The northwards continuation of the monogenetic volcanoes and lava flows that were detailed in the Winnie 3D survey is imaged within the Gallus 2D survey (Fig. IIA-C). To better constrain the distribution of the volcanics in the Gallus 2D survey, the top and bottom of the igneous rocks were mapped. From these, we calculated the isochron thickness of the igneous rocks in the area (Fig. 9A). Like the Winnie 3D survey, volcanism was more pervasive towards the east, with the thickest volcanics ( $\sim 300 \mathrm{~ms}$, approximately 
$163 \mathrm{~m}$ ) located at the eastern edge of the survey. The northernmost extent of the Warnie Volcanic Province is recognised in the Madigan 3D survey where two monogenetic vents were identified within the seismic data. Although, neither vent was penetrated by a well and no surface flows were mapped away from the vents, it seems likely that they are volcanic in origin due to their similarity with the other volcanoes in the Nappamerri Trough.

We have also interpreted one feature within the Warnie Volcanic Province as a diatreme. Maar-diatreme volcanism can occur where a volcanic pipe forms through gaseous explosions that cut into the country rock (Fig. $4 \mathrm{E}-\mathrm{H}$ ) (White \& Ross, 20II). These explosions form a maar (the crater and associated ejecta ring) and a diatreme (the root to the maar), consisting of a steep-sided cone shaped structure filled with pyroclastic, volcanic and country rocks) (White \& Ross, 20II). Unlike vents and associated lava flows, they consist of downward dipping reflectors that truncate the underlying stratigraphy with typically chaotic internal reflectors (Fig. 4F). Spectral decomposition proved to be the most powerful tool for identifying maar-diatremes above the Nappamerri Trough, as the circular crater morphology stood out against the surrounding sediments (Fig. 4G). One feature interpreted to be a diatreme was identified within the survey, displayed in detail in (Fig. 4). It is $\sim 2.25 \mathrm{~km}^{2}$ and $\sim 120 \mathrm{~m}$ deep (I50 ms, TWT) and is found in the west of the Winnie 3D survey (see Fig. 6).

\section{Description of Intrusive Igneous Rocks}

\section{I Well Data}

Igneous rocks intersected within the Warnie East I well are lithologically unique amongst the igneous rocks penetrated by wells in the WVP. Located at $2103 \mathrm{~m}$ depth within the Permian Toolachee Fm (Fig. 10), the 65 m thick basalt is described in the end of well report as fine grained and dominated by plagioclase laths intergrown with augite (Boothby, 1986). The upper $12 \mathrm{~m}$ of the volcanics are described as altered and calcareous, containing phenocrysts of augite with minor pale green talc and minor calcite veining.

Vitrinite reflectance data was acquired within the Warnie East I well. (Fig. IOB). Samples of vitrain were obtained and mean maximum reflectance of vitrinite calculated (Smith, 1987). 
367 Vitrinite reflectance samples adjacent (directly above and below) to the basalt show a marked increase to $4.5 \%$ relative to surrounding Toolachee sediments that are typically 1.5 1.75\%. Whereas extrusive volcanics appear to have little thermal effect on the surrounding sediments (e.g. Grove et al., 2017), igneous intrusions typically show uniform heating on either side of the volcanics, as is observed here (Aarnes et al., 2015). Coupled with its stratigraphic position within the Permian Toolachee Fm., where no other volcanics have been documented within the Cooper Basin, we suggest that Warnie East I contains the sole identified well intersection of an igneous intrusion in the WVP.

\subsection{Seismic Data}

376 Intrusive igneous rocks are also identified within the seismic data available. A 2D seismic 377 reflection line was available that runs across the location of the Warnie East I well (Fig. I I). 378 Unlike the Lambda I and Orientos 2 volcanics, the igneous rocks within the Warnie East I well sit within the Toolachee Fm., a highly reflective sequence of heterogeneous lithologies consisting of sandstones, siltstones and coals. As such, the igneous rocks are difficult to distinguish on seismic reflection survey data, although a shallow saucer-shaped reflection intersects the well path of the Warnie East I well at the depth that igneous rocks are located. The reflection is $\sim 1.5 \mathrm{~km}$ wide and transects the Toolachee Fm. over a depth range of $50 \mathrm{~ms}$. The shallow saucer shape that the reflection event exhibits is common among igneous intrusions within sedimentary basins, corroborating with the well data that suggests the igneous rocks are intrusive in nature.

Igneous intrusions within the Winnie 3D survey are identified as igneous rocks that cross-cut the Triassic to Jurassic strata; notably the Nappamerri, Hutton and Birkhead Fms (e.g. Fig. 12). We identified and mapped I4 intrusions in the seismic data; these occur $\sim 100$ $200 \mathrm{~ms}(\sim 105-210 \mathrm{~m})$ below the palaeosurface. Most of the sills identified are of a similar scale to the lava flows in the area $(2-4.5 \mathrm{~km}$ long, $1.2-1.7 \mathrm{~km}$ wide).

The Winnie 3D survey also hosts a spectacular single intrusion, $14 \mathrm{~km}$ long and 8 $\mathrm{km}$ wide, by far the largest igneous feature in the WVP (Fig. 12). Classical intrusion-related features such as inflation lobes are observed within spectral decomposition (Fig. I2C). Around 20 vents cross-cut this intrusion (see pockmarks on Fig. 12C), in places leading to extrusive lava flows in the overlying sediments (see surface flows on Top Birkhead overlying the intrusion in Fig. 12B). The presence of the pockmarks on the surface of the intrusion 
suggest emplacement of the sill predated a later stage of volcanism that occurred towards the top of the Birkhead Fm.

\section{Description of Altered Igneous Rocks}

This study has so far dealt with igneous rocks of a very consistent lithology preserved within or above the Central Nappamerri Trough. However, the Kappa I well and Snowball 3D seismic reflection survey, located on the very southern edge of the mapped extent of the WVP, preserve igneous rocks of a very different character (Figs. 13-15).

\section{I Well Data}

The Kappa I well was drilled in 1997 on behalf of Santos Limited with the aim of evaluating hydrocarbon presence within the Toolachee, Patchawarra and Epsilon formations (Allen, 1998). Kappa I is located above a large anticline and is the southernmost of a string of prospects located above the northeast Della-Nappacoongee Ridge, which deepens northwards into the Nappamerri Trough (Fig. I). Between 1895 and $2115 \mathrm{~m}$, the Kappa well intersected a $120 \mathrm{~m}$ thick succession of igneous rocks below a thinned $21 \mathrm{~m}$ succession of Hutton Sandstone (Fig. I3). Within the well report, the igneous rocks are ascribed a late Permian to Middle Triassic age (Allen, 1998).

Although core description or in-depth petrological work was not undertaken during this study, rock chips and cuttings of the igneous rocks are described extensively within the Kappa I end of well report (Allen, 1998). Due to the large amount of alteration, the volcanics are described as a chloritized basalt with abundant plagioclase, chlorite, carbonates and quartz. However, the well report distinguishes two types of igneous rocks. Firstly, a vesicular microporphyritic basalt was described that consists of olivine and pyroxene phenocrysts contained within a fine grained or glassy groundmass. Secondly, a less abundant coarse-grained holocrystalline basalt that is composed of randomly oriented plagioclase laths, ferromagnesian crystals and accessory magnetite plus ilmenite. Importantly, and pervasively throughout the succession, a fibrous chlorite is described as having replaced much of the ferromagnesian minerals and groundmass as well rimming and filling vesicles within the basalt.

The Igneous succession in Kappa I also has an unusual petrophysical expression. In our interpretation, we have divided the volcanics into two facies based on the above description; 
a volcaniclastic breccia and in-situ basalt (Fig. 13). The in-situ basalt (e.g. the section between $1900 \mathrm{~m}$ and $1960 \mathrm{~m}$ (Fig. 13)) has a 'saw-tooth' response with a relatively low gamma response of $\sim 40$ api. Acoustic velocities from the sonic velocity log $\left(\sim 4 \mathrm{kms}^{-1}\right)$ are consistently lower than those observed in the Lambda I and Orientos 2 wells $\left(\sim 5.5-6 \mathrm{kms}^{-}\right.$ '). The chaotic, saw-tooth response is indicative of the highly altered nature of the volcanic succession in Kappa I and can be diagnostic of compound lava flows (Millet et al., 2016; Hardman et al., 2019) (Fig. 18). The resistivity throughout the section consistently measures I5 $\Omega \mathrm{m}$. As with the Lambda I well, we constructed a velocity histogram for the igneous rocks in the Kappa I well. When compared to Nelson et al.'s velocity histograms (2009) the best match was with that of Compound-braided flows (Fig. I3B). However, the upper half of Nelson et al.'s (2009) histogram is missing in the Kappa I volcanics, suggesting that the more crystalline, high velocity material is either absent or has been altered to lower velocity material.

442 The volcaniclastic breccia is described as consisting of poorly sorted, subangular, volcaniclastic igneous rock of very fine sand to granule size (Allen, 1998). The log response for the volcaniclastic breccia is characterised by a jagged petrophysical response when compared to the in-situ basalt. Although the gamma ray values ( 40 api) are similar to those of the in-situ basalt, the acoustic velocities (between 2800 and $4 \mathrm{kms}^{-1}$ ) are consistently lower. Furthermore, the volcaniclastic breccia is water saturated with a resistivity of $2-3$ $\Omega m$, although this may also reflect the magnetite and ilmenite within the basalt. Finally, below $2050 \mathrm{~m}$ to the base of the volcanic succession, the caliper tool widened significantly suggesting that the volcaniclastics in this part of the succession are considerably unconsolidated and/or fractured.

\subsection{Seismic Data}

The top of the Kappa I volcanics is interpreted to correlate with a bright, laterally continuous reflection that was present across the whole of the Snowball 3D survey (Figs. I4 \& I5). Above the top Kappa I volcanics a second reflector, deemed here the 'Top Volcanic Mounds,' was mapped in parts of the Snowball 3D survey adjacent to a series of mound-like structures, appearing in places to downlap onto the top Kappa I volcanics (Fig. I5). The centres of these-mound shaped structures are marked by a notable brightening of the reflectors and they are underlain by vertical vents similar to those seen in the other surveys. We thus interpret these mound structures to be a series of volcanic edifices. 
461 The volcanics present in the Snowball 3D survey are notably different to those preserved in the Nappamerri Trough (e.g. Fig 7-9). Rather than isolated, monogenetic vents or flows, they are interpreted to represent a thick package (up to $~ 150 \mathrm{~ms}$ ) of mixed volcanics and volcaniclastic breccias (based on evidence from Kappa I) that thin towards the southwest of the survey (Fig. 15A) (i.e. the southern edge of the Nappamerri Trough). Although the true extent of them is not imaged within the survey (they are interpreted to extend beyond the survey limits to the northeast), laterally they extend over $6 \mathrm{~km}$.

\section{Geophysical Surveys of the Nappamerri Trough}

Alongside seismic and well data, airborne geophysical surveys were examined in order to further delineate the regional distribution of the WVP (Fig. 2IA). A gravity data grid was downloaded from the Queensland Government's data repository. The grid is a compilation of open file gravity surveys collected by exploration companies and State and Federal regional surveys, compiled in 2014. In southwest Queensland, the Nappamerri Trough is typically characterized by a broad gravity low. However, a pronounced $\sim 50 \times 50$ $\mathrm{km}$ gravity high is apparent in the northeast Nappamerri Trough (Fig. 16A). Furthermore, the quantity of mapped intrusive and extrusive volcanics increases towards the centre of this $50 \times 50 \mathrm{~km}$ gravity anomaly (Fig. IB). This corresponds with an increase in the thickness of igneous rocks mapped within seismic data (see Figs. 2, 7 and 9).

In addition to gravity data, a IVD magnetic intensity survey has been analysed that was also downloaded from the Queensland Government's data repository (Fig. 16B). The first vertical derivate filter enhances the high frequency content in the survey, highlighting magnetic anomalies caused by shallow sources such as igneous rocks that are situated at shallower depths than the base of the Cooper Basin succession. The Nappamerri Trough is generally marked by a low in the magnetic intensity whilst the bounding ridges are magnetic highs. However, within the Nappamerri Trough, many small $\left(<8 \mathrm{~km}^{2}\right)$ circular magnetic anomalies can be observed (Fig. 16B). Basalt is highly susceptible to being magnetised (Tarling, 1966), which has facilitated the recognition of buried volcanic rocks elsewhere in the world (Segawa \& Oshima, 1975). Notably, many of the smaller magnetic anomalies do correspond to the location of igneous rocks in the Winnie 3D survey (Fig. 16C).

When the gravity data is superimposed on top of the magnetic data, there is a clear correlation between the location of igneous rocks interpreted using seismic data, the magnetic anomalies and the gravity high identifiable within the Nappamerri Trough (Fig. 16D 
\& E), suggesting that regional geophysical surveys help to constrain the distribution and location of the WVP and other intraplate volcanic provinces. Perhaps most interesting is that the correlation between circular magnetic anomalies and areas with a strong gravity response can be extended beyond the area of the WVP interpreted during this study (Fig. 16E). To the east and southeast of this study, circular magnetic anomalies appear to be coincident with gravity highs. If these anomalies are proven to be volcanic in nature, the extent of the Warnie Volcanic Province could be greater than the interpreted $7500 \mathrm{~km}^{2}$.

\section{The Age of the Warnie Volcanic Province}

This study has detailed the character and extent of igneous rocks within the Cooper and Eromanga basins which has facilitated a regional overview of the WVP (Fig. 17). Here we synthesise the different methods used to define an age range for the eruption and emplacement of the igneous rocks.

\section{Previous Geochemical Analyses}

K-Ar dating was conducted on both the Lambda I extrusive basalt and the Warnie East I intrusive basalt. In the Lambda I well, K-Ar dating was conducted on a bag of drill cuttings taken from a depth of $1658 \mathrm{~m}$ by Murray (1994). Although the samples are described as being too altered to be used for total rock analysis, fresh plagioclase within the cuttings was separated for analysis and used to determine an age of $227+/-3 \mathrm{Ma}$, suggesting emplacement of the basalt during the early Triassic (Murray, 1994). However, in Lambda-I, the basalt is situated between the Jurassic Birkhead Fm. and the Triassic Nappamerri Gp., supporting a Late Triassic to Jurassic age (Draper, 2002). K-Ar dating of basaltic volcanic rocks is often unreliable (Schofield et al., 2017), due to unquantified argon loss (Kelley, 2002). It is noted within the well report that the loss of argon due to subsequent thermal events or contamination of drill cuttings is not accounted for in the quoted error (Murray, 1994).

Within the Warnie East I well, K-Ar dating was conducted on a sample of drill core from $2163 \mathrm{~m}$ (Murray, 1994). Again, the rock was too altered to be used for whole rock K-Ar analysis and, instead, unaltered pyroxene was used for dating. A middle Cretaceous age of $100 \pm 9$ Ma was calculated (Murray, 1994), significantly younger than the rest of the WVP and the Permian host rock within which the intrusion is located. This disparity in the ages determined by K-Ar dating led Draper (2002) to deem the the age dating as 'equivocal.' 
Whilst K-Ar dating is considered be relatively unreliable, there are a number of other agedating techniques that could be conducted on cuttings or core from the Warnie Volcanic Province. U-Pb, Re-Os and Ar-Ar could all be analysed to provide independent constraints on the age of the igneous material (Liu et al., 2017). Furthermore, these geochemical measurements can provide insights into the source of these volcanics (Pande et al., 2017) and are an avenue for future work in the area. In the absence of more geochemical data, it is important to consider the K-Ar ages with respect to other data.

\section{Seismic Data}

532 When tied to the seismic data, the Hutton Sandstone and equivalent sediments (not 533 penetrated by the Lambda I well) are seen to onlap the Lambda I volcanics. The lava flow extending away from Lambda I sits atop Triassic Nappamerri Group sediments of the Cooper Basin whereas the volcanics penetrated by Lambda I appear to cross cut the Triassic stratigraphy.

The timing of igneous activity within the Winnie 3D survey was constrained by the stratigraphic relationship between igneous activity and the Triassic to Jurassic stratigraphy in the study area. In places, intrusions are observed to have caused forced folding of the overburden, as evidenced by onlap of Birkhead Fm. sediments onto the deformed overburden overlying the intrusions (Fig. 12B). Onlap of sedimentary rocks onto these forced folds was used to constrain the age of the intrusion (Trude et al., 2003), whilst the strata-concordant lava flows elsewhere in the survey were assigned an approximate age based on their stratigraphic level. We estimate that volcanism lasted throughout deposition of the Hutton and Birkhead formations between $\sim 178$ and $160 \mathrm{Ma}$, with the youngest volcanics identified as surface flows emplaced on the top Birkhead marker horizon (Alexander \& Hibburt, 1996).

Similarly, in the Gallus 2D survey whilst none of the volcanics were intersected by any wells, the approximate stratigraphic age was constrained by the nearby Halifax and Etty wells (Fig. 9C), placing the volcanics within the Hutton and Birkhead formations, as found for the Winnie 3D survey.

The Madigan 3D volcanics appear to sit near the top of the Nappamerri Group, however, this would place them in the middle Triassic $\sim 240 \mathrm{Ma}, \sim 60$ Myrs older than the rest of the WVP. An alternative explanation would be the emplacement of these vents at the very base 
555 of the Jurassic in this region (a maximum age of $\sim 200 \mathrm{Ma}$, Fig. 2), as they appear to cross-cut all of the Triassic Nappamerri Group strata. This second explanation is preferable as it would fit with the igneous rocks observed throughout the rest of the WVP.

We conclude that the vast majority of igneous rocks identified using seismic reflection data and well data throughout this study can be constrained to a broad age range between $\sim 180$ and $160 \mathrm{Ma}$, spanning the Middle Jurassic. Further work is encouraged to better define the age of the Warnie Volcanic Province, particularly geochemical analyse that would help constrain both the origin and timing of volcanism.

\section{Discussion}

\section{I The Origin of Altered Volcanics Within the Warnie Volcanic Province}

The nature of the igneous rocks within the Kappa I well and Snowball 3D survey is distinct when compared to the rest of the Warnie Volcanic Province, consisting of a mixed sequence of in-situ basalt and volcaniclastics breccias. What isn't clear, however, is the origin of the volcanics. Within the Kappa-I well report, the sequence is described as pyroclastic in nature (Allen, 1998). Whilst this interpretation can account for some of the altered volcaniclastics, it does not explain the extensive sequence of altered basalt. An alternative explanation may be differing sedimentation and eruption rates within the Eromanga leading to prolonged exposure of volcanic rocks emplaced on the rim of the Nappamerri Trough. However, Mid-Late Jurassic sedimentation rates at Kappa I of 2.4 m.my ${ }^{-1}$ (calculated by dividing the thickness of the Hutton to Adori succession by a duration of 23 Myrs) are not significantly lower than those in the Warnie or Lambda wells (2.8 and $2.5 \mathrm{~m} . \mathrm{my}^{-1}$ respectively). Hence, alteration does not appear to be a consequence of extensive surface exposure.

A more compelling explanation for the Kappa I volcanics is hydrothermal alteration. In volcanic regions, many lakes are typically fed by hot springs. In the East African Rift, discharge of hydrothermal water can produce authigenic chlorite with calcite and quartz forming pore filling cements (Renaut et al., 2002). These minerals, particularly chlorite, are noted extensively within the petrological description of the Kappa I well. Additionally, the Kappa I well lies above the Kinta structural trend which could have provided a pathway for 
585 hydrothermal fluids into the Eromanga succession. Basin-wide hydrothermal fluid circulation has been noted within the Cooper Basin (Middleton et al., 20I4, 20I5). In the Nappamerri Trough, these fluids are believed to have formed due to rifting of the eastern Australian margin during the mid-Cretaceous (Middleton et al., 20I5), post-dating the emplacement of the Warnie Volcanic Province. We propose that the Kappa I well represents a succession of volcaniclastic and primary volcanic rocks that was highly altered by hydrothermal fluids.

\subsection{Structural Controls on the Emplacement of the Warnie Volcanic Province}

From the late Triassic to the early Jurassic, the Eromanga Basin was subject to an east-west compressional event named the Hunter-Bowen event (Kulikowski \& Amrouch, 2017), which uplifted the basin and inverted the major highs. Subsequently, the basin underwent postcompressional flexural relaxation with the resultant accommodation space infilled by the Middle to Late Jurassic succession discussed within this manuscript (Lowe-Young, 1997). During this time, a strike-slip extensional regime is thought to have been present in southwest Queensland (Kulikowski et al., 2018). In this context, it is interesting to consider whether the stress regime of the Cooper Basin helped to control the location and morphology of igneous rocks within the WVP and, more broadly, the location of the WVP within central Australia.

\subsection{The Influence of Basement Structure on the Location of Igneous Rocks}

Within other basins, such as those in the North Atlantic, it has been noted how the location of igneous intrusions and volcanism is controlled by the basin structure, in particular the location of major faults (Schofield et al., 2017; McCLlean et al., 2017; Hardman et al., 2019). To investigate whether basement structure and faulting had a direct control on volcanism erupted during the Jurassic, we have utilised the 3D seismic reflection datasets available.

The basin structure of the eastern Nappamerri Trough is largely obscured by the thick Cooper and Eromanga Basin fill and the highly reflective coals of the Permian Toolachee and Patchawarra Fms that make imaging of deeper sediments difficult. Of all the 3D seismic reflection surveys available for this study, only the Winnie 3D survey imaged reflections 2800 ms deep within the Nappamerri Trough (Fig. 3)(approximately $4.3 \mathrm{~km}$ subsurface depth based on the Charal-I time-depth relationship). Notably, the exact lithology of this reflection is unclear, largely due to the lack of any intersections in the Central Nappameri 
616 wells. Unlike the flat-lying Cooper and Eromanga stratigraphy, these deep reflections were often inclined at an angle of $\sim 10^{\circ}$ (taken with the scale set so that Is TWT depth $=1 \mathrm{~km}$ distance laterally). Although not confidently picked throughout the whole of the Winnie 3D survey, the reflections can be mapped over an area of $\sim 600 \mathrm{~km}^{2}$ (Fig. I8B). We interpret these to represent the top Basement in the Nappamerri Trough.

When mapped and imaged in plan view, it is clear that the most major offset (a $\sim 400 \mathrm{~ms}$

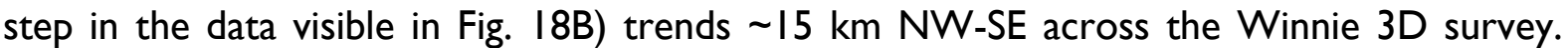
The same $400 \mathrm{~ms}$ step has been noted by previous mapping (SA Department for Manufacturing, Innovation, Trade, Resources and Energy, 2003) where it is visible on a top basement map in the eastern Nappamerri Trough. We interpret offset of the top basement as faulting and, so that it may be easily referred to throughout the text, name the major 400 ms offset the Central Nappamerri Fault.

In order to better relate the igneous activity in the area to the basement structure the distribution of the monogenetic vents within the Winnie 3D survey is considered with respect to these deep basement reflectors. Beneath the vents and volcanoes of the Winnie 3D survey, the seismic reflection data exhibited a velocity pull-up effect that could either represent shallow high velocity material (i.e., the vents or volcanoes themselves) or a high velocity feeder zone representing a vertical column of igneous rock or hydrothermally altered host rock. This effect was particularly obvious on the well-imaged Toolachee Fm., which was mapped to constrain the distribution of the pull-up effects or vents throughout the area (Fig. 18A). Underlying the volcanoes are dark patches that are clearly distinguished from the fluvial channels that make up the Toolachee Fm. (Fig. I8A). We have interpreted these as vents that are either hydrothermal vents or basaltic dykes. The position of these vents was highlighted and superimposed on top of the image of the basement reflections (Fig. 18B). The vents broadly fall into two groups, one to the south of the Central Nappamerri Fault and one to the NE of the Central Nappamerri Fault (Fig. 17 and 18B). These groups fall adjacent to the Top Basement reflections or directly above visible offset in the basement where it deepens to $>3600 \mathrm{~ms}$ and is no longer mappable, strongly implying a pervasive structural control on the location of vents in the Winnie 3D survey.

We also superimposed the location of the Madigan 3D volcanoes on top of the SA Department for Manufacturing, Innovation, Trade, Resources and Energy (2003) basement map (Fig. 17). Like the igneous rocks in the Winnie 3D survey, the two volcanoes imaged in 
the Madigan 3D survey sit atop the tip of the $25 \mathrm{~km}$ Challum Fault and atop a second, $\sim 5$ $\mathrm{km}$ fault northwest of the main Challum Fault. The volcanics seem to be located at the stepover between two faults, suggesting it may be a small releasing bend. This reinforces the idea that the location of igneous rocks was largely controlled by zones of weakness within the basins.

\subsubsection{The Influence of Discontinuities and Faults within the Eromanga Succession on the Morphology of lgneous Rocks}

The idea that structure was the principle control on the nature of the volcanics in the WVP can be extended to the morphology of the igneous rocks. In order to consider how basin structure controlled the morphology of igneous rocks within the Nappamerri Trough, the Winnie 3D survey was used to map the length, width and elongate direction of the volcanoes, lava flows and intrusions (Fig. 19). The high quality of the Winnie 3D survey facilitated confident mapping of the outline of individual volcanic events, however, the Gallus 2D and Snowball 3D surveys were not considered as the outline of individual volcanics could not be picked confidently. The data shows that igneous rocks in the area are typically twice as long as they are wide (Fig. 19). Furthermore, almost all the igneous rocks are elongated in a NW-SE direction, closely matching the strike of the faults within the Nappamerri Trough. It is clear that during eruption and emplacement of the igneous rocks, the basin structure exerted a strong control on the morphology of lava flows and igneous intrusions.

In vertical seismic reflection sections, faulting of the Eromanga Basin stratigraphy is not obvious within the Winnie 3D survey, largely due to the considerable noise within the section. However, spectral decomposition produced for the Top Volcanics horizon images discontinuities (shown as black lines) within the colour blend (Fig. 20). These discontinuities are not thought to be a product of the acquisition and processing of the seismic data, due to their non-linear nature and their coincidence with other geological features such as the igneous rocks and the CNF. When mapped, the features form a series of largely NE-SW trending lineaments (Fig. 20). Although imaging of the discontinuities is best in the SW of the survey, where there are fewer igneous rocks, it is evident that many of the igneous rocks are aligned with these features, suggesting they must have exerted some topographical or structural control when the igneous rocks were erupted or emplaced into the Nappamerri Trough (Fig. 20). As they do not resemble any sedimentary features such as valleys or fluvial 
systems, we interpret these features to be faulting or fracturing of the Eromanga succession above the Nappamerri Trough.

Determining the tectonic activity responsible for the faulting within the Nappamerri Trough and, hence, the location and morphology of igneous rocks within the WVP is difficult due to the complex structural and stress history of the Cooper Basin. Throughout the basin, a conjugate set of large NNE-SSW and field scale SE-NW striking dextral strike-slip faults developed under SSE-NNW strike-slip stress conditions (Kulikowski et al., 2018). This is pertinent when applied to the central Nappamerri Trough, as Kulikowski et al. (2018) identified a series of vertical SE-NW structural lineaments with normal displacement to no displacement. Due to their vertical nature, it is thought that these faults developed as strike slip faults during successive periods of flexural relaxation or sag. The faulting identified within this study is also determined to consist of little offset with an orientation that matches that of the strike-slip faulting determined by Kulikowski et al., (20l8) (Fig. 20). We surmise that sag within the basin produced a series of faults that controlled the morphology of igneous rocks in the WVP.

\subsection{The Broader Record of Jurassic Volcanism in Eastern Australia}

We believe it is important to consider the WVP in the context of the broader record of Jurassic volcanic activity in eastern Australia (Table 2 \& Fig. 2I). Coeval with the eruption of the WVP, the Eromanga Basin was undergoing post-compressional flexural relaxation with thermally controlled subsidence in the absence of significant fault control (Gallagher \& Lambeck, 1989). Subsidence has been attributed to subduction of the Pacific plate beneath southern and eastern Australia, during which time rifting also initiated between Australia and Antarctica (Griffiths, 1975; Johnstone et al., 1973).

Evidence for Jurassic volcanic activity is pervasive throughout the sedimentary basins of eastern Australia, manifested by volcanic arc-derived sediment within the Eromanga Basin (Boult et al., 1998), silicic tuffs in the Surat Basin (Wainman et al., 2015) and widespread volcanogenic zircons within the Eromanga Basin (Bryan et al., 1997). This volcaniclastic material is thought to be derived from an acid to intermediate volcanic arc positioned off the coast of Queensland during the Jurassic, however, the remnants of this arc volcanism are yet to be identified (Paton, 1986, Boult et al., 1997). Jurassic alkali basalt has been 
711 intersected on the Marion Plateau ( 400 km east of Townsville in Queensland), although this may also be related to rifting in the region during the Jurassic (Isern et al., 2002).

Around $1500 \mathrm{~km}$ south of the Marion Plateau, mafic and ultramafic igneous rocks are noted throughout the Eastern Highlands and Sydney Basin. Dykes of the Sydney area intrude rocks as young as $235 \mathrm{Ma}$ with $\mathrm{K}-\mathrm{Ar}$ dating suggesting ages of between 193 and $46.9 \mathrm{Ma}$ (McDougall and Wellman, 1976, Embleton et al., 1985, Pells, 1985). To the north west of the Syndey Basin, in New South Wales, lower Jurassic intrusions and volcanics of the Garawilla alkali basalts are noted in the Gunnedah Basin (195-I4I Ma) (Sutherland, 1978, Pratt, 1998, Gurba \& Weber, 200I). The intermediate to mafic Dubbo volcanics are also recognised in New South Wales (236-170 Ma) (Dulhunty, 1976, Embleton et al., 1985, Black, 1998, Warren et al., 1999). Further south of the Sydney and Gunnedah basins, Jurassic volcanics are scattered throughout Victoria and Tasmania (Veevers \& Conaghan, 1984). These include voluminous tholeiitic intrusions in Tasmania (183 Ma) that are thought to have been buried under a thick pile of largely eroded extrusive volcanics that have a detrital zircon age range of I82 $44 \mathrm{Ma}$ (Sutherland, 1978; McDougall \& Wellman, 1976, Bromfield et al., 2007, Ivanov et al., 2017). In Eastern Victoria, Jurassic activity included a 191 Ma dyke swarm of alkali basalts (Soesoo et al., 1999). The geochemical source characteristics of the Eastern Victoria alkalia basalts are suggestive of subcontinental lithospheric mantle, like the proposed source of the Late Cenozoic Newer Volcanic Province in western Victoria (Elburg \& Soesoo, 1999).

Around $1000 \mathrm{~km}$ south of the WVP, the Wisanger Basalt is a $\sim 170 \mathrm{Ma}, 20 \mathrm{~km}$ fragmented lava flow emplaced on top of Permian fluviatile sediments on Kangaraoo Island (McDougall \& Wellman, 1976). Geochemically, it is similar to the Tasmanian and Antarctic tholeiitic dolerite and basalts that are usually attributed to the Ferrar Large Igneous Province and extension that latterly resulted in the separation of Australia and Antarctica (Compston et al., 1968; Milnes et al., 1982). Of note in South Australia, Jurassic kimberlites record the extension of Mesozoic kimberlites found along the margin of southern Gondwana, above the subducting Pacific plate (Tappert et al., 2009), differing petrologically from the predominantly basaltic volcanism found elsewhere in eastern Australia.

Plate reconstructions indicate that the Eromanga Basin was located at significant distances (at least $750 \mathrm{~km}$ ) from the oceanic trench of the subducting Pacific plate (Veevers \& Conaghan, 1984; Ivanov et al., 2017) (Fig. 2I). We therefore believe the Warnie Volcanic Province to be an intraplate volcanic province and, as the origin of intraplate volcanism can 
743 often be contentious (Conrad et al., 20II), it is important to consider the source of this volcanism and implications for the formation of intraplate volcanism.

\subsection{The Origin of the Warnie Volcanic Province}

The WVP was located far from active plate boundaries during the Jurassic (Fig. 2I). When considering the source of intraplate volcanism, several different mechanisms must be considered:

- The presence of a mantle plume

- Asthenospheric upwelling due to extension

- Local scale mantle convection

Mantle plumes are typically associated with the eruption of voluminous flood basalt provinces that often mark the earliest volcanic activity of major hot spots (Richards et al., 1989). Furthermore, mantle plumes cause dynamic uplift of the land's surface of up to several hundred kms followed by surface subsidence due to the withdrawal of mantle plume material and loading of the crust with the volcanic sequence (Nadin et al., 1997; Dam et al., 1998; Hartley et al., 20II; Hardman et al., 2018). No evidence of major surface uplift in the Cooper and Eromanga Basins is coeval with the emplacement and eruption of the WVP (Hall et al., 2016). Furthermore, subsidence and sag throughout the emplacement of the WVP is minor, with no large changes in sedimentary facies noted throughout the Jurassic lower non-marine Eromanga succession (Alexander \& Hibburt, 1996). No major crustal and/or lithospheric extension is evidenced by the lack of major Jurassic faults, during a time in which the basin underwent post-compressional flexural relaxation in a strike slip extensional regime (Lowe-Young, 1997; Kulikowski et al., 2018). Furthermore, the small spatial area covered by the Warnie Volcanic Province $\left(\sim 7500 \mathrm{~km}^{2}\right.$ within the Nappamerri Trough area) and, by extension, the volume of magma emplaced, is too low to be related to a mantle plume source (Conrad et al., 20II).

Low-effusive volcanism occurring within tectonic plates has been also attributed to several locally operating processes, such as minor upwelling plumes, downwelling drops and sub-lithospheric or edge-driven convection (Courtillot et al., 2003; Ballmer et al., 2009; Conrad et al., 20II). In the case of edge-driven convection, mantle flow can induce upwelling and volcanism through interaction with lithospheric or asthenospheric heterogeneities (Conrad et al., 20II; Davies \& Rawlinson, 2014). In the Newer Volcanic Province in South 
774 Australia, $<5 \mathrm{kyr}$ volcanism formed as a product of edge driven convection is noted to consist of basaltic monogenetic volcanoes $<4 \mathrm{~km}^{2}$ in size covering an area of up to 40,000 $\mathrm{km}^{2}$ (Demidjuk et al., 2007; Davies \& Rawlinson, 20I4). This style of volcanism (basaltic, with individual volcanoes like Mount Gambier of a similar scale to the volcanoes imaged in the Nappamerri Trough area $(\sim 1.5 \times 1.5 \mathrm{~km}))$ and the areal extent $\left(7500 \mathrm{~km}^{2}\right.$ that could be extended to almost $20,000 \mathrm{~km}^{2}$ if the magnetic anomalies are found to be igneous in nature) are similar in scale to the igneous rocks in the Newer Volcanic Province. Convection within the asthenosphere can be induced by changes in lithospheric thickness. Although not much is known about the crustal structure below the eastern Nappamerri Trough, seismic reflection profiles have revealed that Devonian troughs to the east of the study area are associated with crustal thinning of 7 - $10 \mathrm{~km}$ (Mathur, 1983). Furthermore, on a continental scale, the Moho is observed to shallow to $\sim 20 \mathrm{~km}$ below the Cooper Basin (and more broadly, Central Australia) (Fig. 2I)(Kennett et al., 20II). Therefore, there is observable lithospheric thinning below the basins in Central Australia that could have produced edge driven convection.

However, because Central Australia was relatively inactive during the Jurassic, we must consider driving mechanisms for asthenospheric flow beneath the continent during the eruption and emplacement of the WVP. As we have already detailed, the Pacific plate was subducting beneath eastern Australia during the Jurassic. In intraplate volcanic provinces adjacent to subduction zones (e.g. Western North America, China), there is a causal link between subduction and intraplate volcanism, in that subduction below the continental crust acts as a driving force for asthenospheric shear and, hence, the mantle upwelling that produces intraplate volcanism (Conrad et al., 20II; Tang et al., 20I4; Zhou et al., 2018). If the extension in the area during the Jurassic is not great enough to stimulate volcanism, then an alternative model may involve rapid asthenospheric shear produced by the subducting Pacific Plate, localised beneath SW Queensland due to edge driven convection.

We propose a model for the Warnie Volcanic Province based on our understanding of the lithospheric and geodynamic state of Central Australia in the Jurassic. We propose that asthenospheric shear above the subducting pacific plate stimulated mantle flow below Australia (Fig. 20B). Localisation of mantle flow occurred beneath southwest Queensland because of edge driven convection lead to emplacement of the Warnie Volcanic Province above the Nappamerri Trough. Despite our proposed model, we strongly believe that more work needs to be conducted on the area before it can be concluded what the source of the 
WVP is. In the Newer Volcanic Province of southeastern Australia, geochemistry, major and trace element analysis, provided insights into the formation of a volcanic province through edge driven convection (Demidjuk et al., 2007). More recent geochemical and geophysical insights have furthered this discussion studies suggesting additional felsic asthenospheric input (Sutherland et al., 20I4), shear-driven upwelling (Oosting et al., 2016) and intermittent volcanism through interaction of transient mechanisms with the passage of a mantle plume (Rawlinson et al., 2017). As such, we would strongly recommend further studies to be conducted on the geochemical signature of the basalts of the WVP.

Due to its low volume, small areal extent and predominantly basaltic nature, we do not believe that the WVP was the source of the volcanically derived sediment that was distributed throughout much of Australia during the Mesozoic (Boult et al., 1998; MacDonald et al., 2013; Barham et al., 2016). However, our findings raise the possibility that other, yet unidentified, intra-basinal volcanic sources may contribute to Mesozoic volcanogenic sedimentation in eastern Australia.

Finally, it must be considered why the WVP has not been documented until now despite the presence of igneous rocks being known for over three decades. By our estimates, only $0.13 \%$ of the wells drilled in the Cooper Basin between 1959 and 2015 drilled the WVP (based on Hall et al., 2016's estimate of the number of wells), with 35 years of exploration since the first well that drilled the volcanics. This is despite the WVP occupying $\sim 6 \%$ of the geographic extent of the Cooper Basin. Largely, this is due to the lack of data and attention given to the Nappamerri Trough region until recently. Acquisition of the high-quality Winnie 3D seismic reflection survey facilitated confident delineation of the WVP. This study also underlines the importance for collaboration between industry and academia. Whilst igneous rocks have been described within industry reports and imaged within data acquired, they have been overlooked within the literature. The obscurity of the WVP in an area of such intense exploration points to the probability of other undiscovered volcanic provinces globally. It is therefore an important analogue in the search for undiscovered intraplate volcanism that may inform our understanding of the mantle processes occurring beneath continental interiors. 
837

\section{Conclusions}

838 We have integrated seismic, well, gravity and magnetic data and clarified the extent and character of igneous rocks emplaced above the Nappamerri Trough of the Cooper Basin within Eromanga Basin stratigraphy. Monogenetic volcanoes, igneous intrusions and altered compound lava flows extending over $\sim 7500 \mathrm{~km}^{2}$ are proposed to have been active between I80 - I60 Ma forming part of the proposed 'Warnie Volcanic Province.' Regionally, the morphology and distribution of igneous rocks is controlled by basement structure. On a continental scale, we interpret the Warnie Volcanic Province to be a product of intraplate convective upwelling above the subducting Pacific slab.

\section{Acknowledgements}

We wish to thank Santos Ltd. for providing us with the Snowball 3D seismic survey. In particular we wish to thank Jenni Clifford and Lance Holmes who provided helpful feedback and 2D seismic lines covering the Lambda I, Orientos 2 and Warnie East I wells. We also wish to thank Beach Energy, in particular Rob Menpes, for the helpful discussions and feedback on the manuscript in addition to helping us with the analysis of the magnetic data. The work contained in this paper contains work conducted during a PhD study undertaken as part of the Natural Environment Research Council (NERC) Centre for Doctoral Training (CDT) in Oil \& Gas [grant number NEM00578X/I] and is fully funded by NERC whose support is gratefully acknowledged. Lastly, the two anonymous reviews of the manuscript are thanked for their insightful and constructive comments that significantly improved the work presented. 


\section{References}

Aarnes, I., Planke, S., Trulsvik, M. and Svensen, H., 20I5. Contact metamorphism and thermogenic gas generation in the Vøring and Møre basins, offshore Norway, during the Paleocene-Eocene thermal maximum. Journal of the Geological Society, I 72(5), pp.588-598.

Alexander, E.M. and Hibburt, J.E., 1996, Petroleum Geology of South Australia, Volume 2: Eromanga Basin.

Allen P., 1998. Kappa I Well Completion Report. Compiled for Santos Limited.

Archer, S.G., Bergman, S.C., lliffe, J., Murphy, C.M. and Thornton, M., 2005. Palaeogene igneous rocks reveal new insights into the geodynamic evolution and petroleum potential of the Rockall Trough, NE Atlantic Margin. Basin Research, I7(1), pp.17I-20I.

Apak, S.N., Stuart, W.J., Lemon, N.M. and Wood, G., 1997. Structural evolution of the PermianTriassic Cooper Basin, Australia: relation to hydrocarbon trap styles. AAPG bulletin, 8I (4), pp.533555.

Ballmer, M.V., Van Hunen, J., Ito, G., Bianco, T.A. and Tackley, P.J., 2009. Intraplate volcanism with complex age-distance patterns: A case for small-scale sublithospheric convection. Geochemistry, Geophysics, Geosystems, 10.

Barham, M., Kirkland, C.L., Reynolds, S., O’Leary, M.J., Evans, N.J., Allen, H., Haines, P.W., Hocking, R.M., McDonald, B.J., Belousova, E. and Goodall, J., 2016. The answers are blowin'in the wind: Ultradistal ashfall zircons, indicators of Cretaceous super-eruptions in eastern Gondwana. Geology, 44(8), pp.643-646.

Bell \& Butcher, 2002. On the emplacement of sill complexes: evidence from the Faroe-Shetland Basin. Geological Society, London, Special Publications(2002), 197(1):307

BlackŁACK L.p. 1998. SHRIMP zircon UIPb isotopic age dating of samples from the Dubbo I:250000 Sheet area, batch 2. Geological Survey of New South Wales, File GSI998/I 27 (unpublished).

Boothby, P.G., 1986. Warnie East I Well Completion Report. Compiled for Delhi Petroleum Pty Ltd.

Boult, P.J., Ryan, M.J., Michaelsen, B.H., McKirdy, D.M., Tingate, P.R., Lanzilli, E. and Kagya, M.L., 1997. The Birkhead-Hutton (!) Petroleum System of the Gidgealpa Area, Eromanga Basin, Australia.

Boult, P.J., Lanzilli, E., Michaelsen, B.H., McKirdy, D.M. and Ryan, M.J., 1998. A new model for the Hutton/Birkhead reservoir/seal couplet and the associated Birkhead-Hutton (!) petroleum system. The APPEA Journal, 38(1), pp.724-744. 
891 Bromfield, K.E., Burrett, C.F., Leslie, R.A. \& Meffre, S., 2007. Jurassic volcani-clastic basaltic andesite dolerite sequence in Tasmania: new age constraints for fossil plants from Lune River. Australian Journal of Earth Sciences, 54, 965-974.

Bryan, S.E., Constantine, A.E., Stephens, C.J., Ewart, A., Schön, R.W. and Parianos, J., 1997. Early Cretaceous volcano-sedimentary successions along the eastern Australian continental margin: Implications for the break-up of eastern Gondwana. Earth and Planetary Science Letters, I53(1), pp.85102

Bucknill, M., 1990. Orientos 2 Well Completion Report. Compiled for Delhi Petroleum Pty Limited.

Burger, D. and Senior, B.R., 1979. A revision of the sedimentary and palynological history of the northeastern Eromanga Basin, Queensland. Journal of the Geological Society of Australia, 26(3-4), Pp. I2I-I33.

Compston, W., McDougall, I. and Heier, K.S., 1968. Geochemical comparison of the mesozoic basaltic rocks of Antarctica, South Africa, South America and Tasmania. Geochimica et Cosmochimica Acta, 32(2), pp.129-149.

Courtillot, V., Davaille, A., Besse, J. and Stock, J., 2003. Three distinct types of hotspots in the Earth's mantle. Earth and Planetary Science Letters, 205, 295-308.

Davies, D.R. and Rawlinson, N., 20I4, On the origin of recent intraplate volcanism in Australia, Geology, v.42, pp. 103 I-1034.

Demidjuk, Z., Turner, S., Sandiford, M., George, R., Foden, J. and Etheridge, M., 2007, U-series isotope and geodynamic constraints on mantle melting processes beneath the Newer Volcanic Province in South Australia, Earth and Planetary Science Letters, ₹.26I, p. 5I7-533.

Draper, J.J. ed., 2002. Geology of the Cooper and Eromanga Basins, Queensland. Department of Natural Resources and Mines

\section{Dulhunty,ULHUNTY J.A. 1976. Potassium-argon ages of igneous rocks in the Wollar-Rylstone} region, New South_Wales. Royal Society of_New South Wales, Journal and Proceedings 109, 35-39.

Elburg, M.A. \& Soesoo, A., 1999. Jurassic alkali-rich volcanism in Victoria (Australia): lithospheric versus asthenospheric source. Journal of African Earth Sciences, 29(1), 269_-280.

Elliot, D.H. and Fleming, T.H., 2004. Occurrence and dispersal of magmas in the Jurassic Ferrar large igneous province, Antarctica. Gondwana Research, 7(1), pp.223-237. 
EmbletonMBLETON B.J.J., SchmidtCHMIDT P.w., HamiltonAMILTON L.H. \& RileyHEY G.H. 1985.

921 Dating volcanism in the Sydney Basin; evidence from K-Ar ages and palaeomagnetism. Geological

922 Society of_Australia, Journal 23, 243-248.

923 Exon, N.F. and Burger, D., 198I. Sedimentary cycles in the Surat Basin and global changes of sea 924 level. Bureau of Mineral Resources Journal of Australian Geology and Geophysics, 6, pp. I53-I59.

925 Fishwick, S., Heintz, M., Kennett, B.L.N., Reading, A.M. and Yoshizawa, K., 2008. Steps in lithospheric 926 thickness within eastern Australia, evidence from surface wave tomography. Tectonics, 27(4).

927 Gallagher, K. and Lambeck, K.U.R.T., 1989, Subsidence, sedimentation and sea-level changes in the 928 Eromanga Basin, Australia, Basin Research, ৮.2, p. II5-|3|.

929 Goldstein, B., Menpes, S., Hill, A., Wickham, A., Alexander, E., Jarosz, M., Pepicelli, D., Malavazos, M., 930 Staritski, K., Taliangis, P., Coda, J., Hill, D. \& Webb, M. 2012. Roadmap for Unconventional Gas 931 Projects in South Australia. South Australia Department for Manufacturing, Innovation, Trade,

Greenstreet, C. 2015. From play to production: the Cooper unconventional story -20 years in the making. APPEA 2015 extended abstract.

Griffiths, J.R., 1975. New Zealand and the Southwest Pacific margin of Gondwanaland. In: K.S.W. Campbell (Editor), Gondwana Geology. A.N.U. Press, Canberra, pp.619- 637.

Grove, C., Jerram, D.A., Gluyas, J.G. and Brown, R.J., 2017. Sandstone diagenesis in sediment-lava sequences: exceptional examples of volcanically driven diagenetic compartmentalization in Dune Valley, Huab Outliers, NW Namibia. Journal of Sedimentary Research, 87, I3 |4-I 335.

Gurba, L.W. and Weber, C.R., 200I, Effects of igneous intrusions on coalbed methane potential, Gunnedah Basin, Australia, International Journal of Coal Geology, ๖.46, p. I I3-I3 I.

Hall, L.S., Hill, A.J., Troup, A., Korsch, R.J., Radke, B.M., Nicoll, R.S., Palu, T., Wang, L. and Stacey, A., 2016, Cooper Basin Architecture and Lithofacies, Geoscience Australia.

Hall, L.S, Palu, T.J., Murray, A.P., Boreham, C.J., Edwards, D.S., Hill, A.J., Troup, A., 2018. Hydrocarbon Prospectivity of the Cooper Basin, Australia. AAPG Bulletin.

\footnotetext{
Hamilton, D.S., Holtz, M.H., Ryles, P., Lonergan, T. and Hillyer, M., 1998. Approaches to identifying reservoir heterogeneity and reserve growth opportunities in a continental-scale bed-load fluvial system: Hutton Sandstone, Jackson field, Australia. AAPG bulletin, 82(12), pp.2192-2219.
} 
951 Hardman, J.P., Schofield, N., Jolley, D.W., Holford, S.P., Hartley, A.J., Morse, S., Underhill, J.R., Watson, D.A. and Zimmer, E.H., 2018. Prolonged dynamic support from the Icelandic plume of the NE Atlantic margin. Journal of the Geological Society, I75(3), pp.396-4I0.

Hardman, J., Schofield, N., Jolley, D., Hartley, A., Holford, S. and Watson, D., 2019. Controls on the distribution of volcanism and intra-basaltic sediments in the Cambo-Rosebank region, West of Shetland. Petroleum Geoscience, 25(H), pp.7I-89.

Hillis, R.R., Morton, J.G.G., Warner, D.S. and Penney, R.K., 200I. Deep basin gas: A new exploration paradigm in the Nappamerri Trough, Cooper Basin, South Australia. The APPEA Journal, 4I(1), pp. 185-200.

Isern, A.R., Anselmetti, F.S. and Blum, P., 2002. Constraining Miocene sea level change from carbonate platform evolution, Marion Plateau, northeast Australia, Sites I192-1 199. In Proceedings of the Ocean Drilling Program. Initial Reports, (Vol. 194, p.88.)

Ivanov, A.V., Meffre, S., Thompson, J., Corfu, F., Kamenetsky, V. S., Kamenetsky, M.B. \& Dementrova, E. I., 20I7. Timing and genesis of the Karoo-Ferrer large igneous province: New high precision U-Pb data for Tasmania confirm short duration of the major magmatic pulse. Chemical Geology, 455, 3243.

Jerram, D.A. \& Widdowson, M. 2005. The anatomy of Continental Flood Basalt Provinces: geological constraints on the processes and products of flood volcanism. Lithos, 79(3), 385-405.

Johnstone, M.H., Lowry, D.C. and Quilty, P.G., 1973. The geology of South-western Australia - a review. J. Proc. R. Sot. West. Aus., 56 $\div 5-15$.

Kapel, A., 1966. The Cooper's Creek Basin. The APPEA Journal, 6, 71-75.

Kelley, S.2 (2002.) K-Ar and Ar-Ar Dating, in noble gases in geochemistry and cosmochemistry. In: Reviews in Mineralogy and Geochemistry, Vol.47 (Ed. by D. Porcelli, C.J. Ballentine \& R. Wieler),-pp. 785-818, Mineral Society America, Washington, DC.

Kennett, B., Salmon, M., Saygin, E. and AusMoho Working Group, 201 I.-, AusMoho: the variation of Moho depth in Australia, Geophysical Journnfal International, 187, 946-958.; 2011, doi:10.1111/j.1365-246X.2011.05194.x

Khair, H.A., Cooke, D. and Hand, M., 20I3. The effect of present day in situ stresses and paleostresses on locating sweet spots in unconventional reservoirs, a case study from Moomba-Big Lake fields, Cooper Basin, South Australia. Journal of Petroleum Exploration and Production Technology, 3(4), рр.207-221. 
982 Khair, H.A., Cooke, D. and Hand, M., 2015. Paleo stress contribution to fault and natural fracture

1

2

3

distribution in the Cooper Basin. Journal of Structural Geology, 79, pp-3I-4I.

Kuang, K.S., 1985. History and style of Cooper? Eromanga Basin structures. Exploration Geophysics, 16(3), pp.245-248.

Kulikowski, D., Amrouch, K., Al Barwani, K.H.M., Liu, W. and Cooke, D., 20I5, September. Insights into the Tectonic Stress History and Regional 4-D Natural Fracture Distribution in the Australian Cooper Basin Using Etchecopar's Calcite Twin Stress Inversion Techn̨bique. In International Conference \& Exhibition.

Kulikowski, D. and Amrouch, K., 2017. Combining geophysical data and calcite twin stress inversion to refine the tectonic history of subsurface and offshore provinces: A case study on the Cooper-Eromanga Basin, Australia. Tectonics, 36(3), pp.5I5-54I.

Kulikowski, D., Amrouch, K., Cooke, D. and Gray, M.E., 20I8, Basement structural architecture and hydrocarbon conduit potential of polygonal faults in the Cooper-Eromanga Basin,

Australia, Geophysical Prospecting, v. 66, p. 366-396.

Lanzilli, E., 1999. The Birkhead Formation: reservoir characterisation of the Gidgealpa south dome and sequence stratigraphy of the Eromanga Basin, Australia (Doctoral dissertation, University of South Australia).

Liu, P., Mao, J., Cheng, Y., Yao, W., Wang, X. and Hao, D., 2017. An Early Cretaceous W-Sn deposit and its implications in southeast coastal metallogenic belt: Constraints from U-Pb, Re-Os, Ar-Ar geochronology at the Feie'shan W-Sn deposit, SE China. Ore Geology Reviews, 81, 112-122.

Lowe-Young, B.S., Mackie, S.I. and Heath, R.S., 1997. The Cooper-Eromanga petroleum system, Australia: Investigation of essential elements and processes.

MacDonald, J.D., Holford, S.P., Green, P.F., Duddy, I.R., King, R.C. and Backé, G., 20I3. Detrital zircon data reveal the origin of Australia's largest delta system. Journal of the Geological Society, I 70(1), pp-3-6.

Mackie, S., 2015, September. History of petroleum exploration and development in the Cooper and Eromanga basins. In AAPG/SEG International Conference \& Exhibition, Melbourne, Australia. Search and Discovery Article \#10814

Magee, C., Jackson, C.L. and Schofield, N., 2014. Diachronous sub-volcanic intrusion along deep-water margins: Insights from the Irish Rockall Basin. Basin Research, 26(I), pp.85-105.

Mathur, S.P., 1983, Deep crustal reflection results from the central Eromanga Basin, Australia, Tectonophysics, $\vee$. 100,_-pp-163-173. 
McDougall, I. \& Wellman, P. 1976. Potassium argon ages for some Australian Mesozoic igneous rocks. Journal of the Geological Society of Australia, 23, I-9.

McLean, C.E., Schofield, N., Brown, D.J., Jolley, D.W. and Reid, A., 2017. 3D seismic imaging of the shallow plumbing system beneath the Ben Nevis Monogenetic Volcanic Field: Faroe-Shetland Basin. Journal of the Geological Society, I74(3), pp.468-485

Meeuws, F.J., Holford, S.P., Foden, J.D. and Schofield, N., 20I6. Distribution, chronology and causes of Cretaceous-Cenozoic magmatism along the magma-poor rifted southern Australian margin: Links between mantle melting and basin formation. Marine and Petroleum Geology, 73, pp.27I-298.

Meixner, T.J., Gunn, P.J., Boucher, R.K., Yeates, T.N., Richardson, L.M. and Frears, R.A., 2000. The nature of the basement to the Cooper Basin region, South Australia. Exploration Geophysics, $3 /(2)$, Pp.24-32.

Menpes, S., Hill, A.J. \& Pepicelli, D. 2013. Characteristics of the Gidgealpa Group Composite Resource Play in the Cooper Basin, South Australia. Unconventional Resources Technology Conference, Denver, 2013.

Middleton, A.W., Uysal, I.T., Bryan, S.E., Hall, C.M. and Golding, S.D., 20I4. Integrating 40Ar-39Ar, $87 \mathrm{Rb}-87 \mathrm{Sr}$ and $147 \mathrm{Sm}-143 \mathrm{Nd}$ geochronology of authigenic illite to evaluate tectonic reactivation in an intraplate setting, central Australia. Geochimica et Cosmochimica Acta, 134, pp.I55- 174.

Middleton, A.W., Uysal, I.T. and Golding, S.D., 2015. Chemical and mineralogical characterisation of illite-smectite: Implications for episodic tectonism and associated fluid flow, central Australia. Geochimica et Cosmochimica Acta, 148, pp.284-303.

Millett, J.M., Hole, M.J., Jolley, D.W., Schofield, N. and Campbell, E., 2016. Frontier exploration and the North Atlantic Igneous Province: new insights from a $2.6 \mathrm{~km}$ offshore volcanic sequence in the NE Faroe-Shetland Basin. Journal of the Geological Society, I 73(2), pp.320-336.

Milnes, A.R., Cooper, B.J. and Cooper, J.A., 1982. The Jurassic Wisanger Basalt of Kangaroo Island, South Australia. Transactions of the Royal Society of South Australia, 106, pp.I-I3.

Murray, C.G., 1994. Basement cores from the Tasman fold belt system beneath the Great Artesian Basin in Queensland. Department of Minerals and Energy, Queensland.

Nadin, P.A., Kusznir, N.J. and Cheadle, M.J., 1997, Early Tertiary plume uplift of the North Sea and Faeroe-Shetland basins, Earth and Planetary Science Letters, v. I 48,_-_. 109-I 27.

Nelson, C.E., Jerram, D.A. and Hobbs, R.W., 2009, Flood basalt facies from borehole data: implications for prospectivity and volcanology in volcanic rifted margins, Petroleum Geoscience, $\vee_{.}$. 15, p. 313-324. 
Németh, K., 2010. Monogenetic volcanic fields: Origin, sedimentary record, and relationship with polygenetic volcanism. What is a Volcano?, 470, p.43.

Németh, K. and Kereszturi, G., 2015. Monogenetic volcanism: personal views and discussion. International Journal of Earth Sciences, 104(8), pp.2I 3I-2I 46.

Oostingh, K.F., Jourdan, F., Merle, R. \& Chiradia, M., 2016. Spatio-temporal geochemical evolution of the $\mathrm{SE}$ Australian upper mantle deciphered from the $\mathrm{Sr}, \mathrm{Nd}$ and $\mathrm{Pb}$ isotope compositions of Cenozoic intraplate volcanic rocks. Journal of Petrology, 57, I509 - 1530.

Pande, K., Cucciniello, C., Sheth, H., Vijayan, A., Sharma, K.K., Purohit, R., Jagadeesan, K.C. and Shinde, S., 2017. Polychronous (Early Cretaceous to Palaeogene) emplacement of the Mundwara alkaline complex, Rajasthan, India: $40 \mathrm{Ar} / 39 \mathrm{Ar}$ geochronology, petrochemistry and geodynamics. International Journal of Earth Sciences, 106, 1487-1504.

Paton, I.M., 1986, The Birkhead Formation-a Jurassic petroleum reservoir, in D.I. Gravestock, P.S. Moore, and G.M. Pitt, (eds.), Contributions to the Geology and Hydrocarbon Potential of the Eromanga Basin: Geological Society of Australia Special Publication No. 12, p. 195-20I.

Pells, P.J.N., 1985. Engineering geology of the Sydney Region, 407, Pp. Routledge, London.

Pitkin, M.C., Wadham, T.H., McGowen, J.M. and Thom, W.W., 20I2, January. Taking the first steps: Stimulating the Nappamerri Trough resource play. In SPE Asia Pacific Oil and Gas Conference and Exhibition. Society of Petroleum Engineers.

Planke, S., Symonds, P.A., Alvestad, E. and Skogseid, J., 2000. Seismic volcanostratigraphy of large-volume basaltic extrusive complexes on rifted margins. Journal of Geophysical Research: Solid Earth, 105(B8), pp.19335-1935I.

Planke, S., Rasmussen, T., Rey, S.S. and Myklebust, R., 2005, January. Seismic characteristics and distribution of volcanic intrusions and hydrothermal vent complexes in the Vøring and Møre basins.

In Geological Society, London, Petroleum Geology Conference series, (Vol.6, No. 1, pp.833-844).. Geological Society of London.

Planke, S., Millett, J.M., Maharjan, D., Jerram, D.A., Abdelmalak, M.M., Groth, A., Hoffmann, J., Berndt, C. and Myklebust, R., 2017. Igneous seismic geomorphology of buried lava fields and coastal escarpments on the Vøring volcanic rifted margin. Interpretation, 5(3), pp.SKI6I-SKI77.

Pratt, W., 1998. Gunnedah Coalfield: notes to accompany the Gunnedah Coalfield regional geology (north and south maps). Report GSI998/505. New South Wales Department of Mineral Resources. Geological Survey of New South Wales, Sydney, I I3.-pp. 
Rawlinson, N., Davies, D.R. \& Pila, S., 2017. The mechanisms underpinning Cenozoic intraplate volcanism in eastern Australia: insights from seismic tomography and geodynamic modelling. Geophysical Research Letters, 44, doi: 10.1002/2017GL0749II.

Reid, A.J., Korsch, R.J., Hou, B. and Black, L.P., 2009. Sources of sediment in the Eocene Garford paleovalley, South Australia, from detrital-zircon geochronology. Australian Journal of Earth Sciences, 56(SI), pp-SI25-SI37.

Renaut, R.W., Jones, B., Tiercelin, J.J. and Tarits, C., 2002. Sublacustrine precipitation of hydrothermal silica in rift lakes: evidence from Lake Baringo, central Kenya Rift Valley. Sedimentary Geology, I 48(1-2), pp.235-257.

Reynolds, P., Holford, S., Schofield, N. and Ross, A., 2017. 3-D Seismic Imaging of Ancient Submarine Lava Flows: An Example From the Southern Australian Margin. Geochemistry, Geophysics, Geosystems.

Richards, M.A., Duncan, R.A. and Courtillot, V.E., 1989. Flood basalts and hot-spot tracks: plume heads and tails. Science, 246(4926), pp.103-107.

Rider, M. and Kennedy, M., 20II. The Geological Interpretation of Well Logs. published by RiderFrench Consulting Ltd.

Russell, M. and Gurnis, M., 1994. The planform of epeirogeny: vertical motions of Australia during the Cretaceous. Basin Research, 6(2-3), pp.63-76.

"SA Department for Manufacturing, Innovation, Trade, Resources and Energy" (2003) National Geoscience Mapping Accord (NGMA) Cooper Eromanga Basins Project - Cooper Formation Depths. Bioregional Assessment Source Dataset. Viewed 27 November 2017, http://www.energymining.sa.gov.au/petroleum/data_and_publications/seismic/cooper_and_e romanga basin mapping_products

Schofield, N. and Jolley, D.W., 2013. Development of intra-basaltic lava-field drainage systems within the Faroe-Shetland Basin. Petroleum Geoscience, 19(3), pp.273-288.

Schofield, N., Holford, S., Millett, J., Brown, D., Jolley, D., Passey, S.R., Muirhead, D., Grove, C., Magee, C., Murray, J. and Hole, M., 2017. Regional magma plumbing and emplacement mechanisms of the Faroe-Shetland Sill Complex: implications for magma transport and petroleum systems within sedimentary basins. Basin Research, 29(1), pp.4I-63.

Scott, M.P., Stephens, T., Durant, R., McGowen, J., Thom, W. and Woodroof, R., 20I3, November. Investigating hydraulic fracturing in tight gas sand and shale gas reservoirs in the Cooper Basin. In SPE Unconventional Resources Conference and Exhibition-Asia Pacific. Society of Petroleum Engineers. 
Segawa, J. and Oshima, S., 1975. Buried Mesozoic volcanic-plutonic fronts of the north-western Pacific island arcs and their tectonic implications. Nature, 256(55/2), p.15.

Short, D.A., 1984. Lambda No.I Well Completion Report. Compiled for Delhi Petroleum Pty. Ltd.

Song, B., Economides, M.J. and Ehlig-Economides, C.A., 2011, January. Design of multiple transverse fracture horizontal wells in shale gas reservoirs. In SPE Hydraulic Fracturing Technology Conference. Society of Petroleum Engineers.

Soesoo, A., Bons, P. \& Elburg, M., 1999 Freestone dykes—an alkali-rich Jurassic dyke population in eastern Victoria. Australian Journal of Earth Sciences, 46-(I-2), $I=-9$.

Smith, 1987. Vitrinite Reflectance/Maceral Analysis of the Warnie East I Well.

Stewart, A.K., Massey, M., Padgett, P.L., Rimmer, S.M. and Hower, J.C., 2005. Influence of a basic intrusion on the vitrinite reflectance and chemistry of the Springfield (No. 5) coal, Harrisburg, Illinois. International Journal of Coal Geology, 63(+ 2), pp.58-67.

Stewart, A.J., Raymond, O.L., Totterdell, J.M., Zhang, W. \& Gallagher, R. 2013. Australian Geological Provinces, 2013.01 edition. scale 1:2 500 000. Geoscience Australia, Canberra, http://www.ga.gov.au/metadata-gateway/metadata/record/83860

Sun, X., 1997. Structural style of the Warburton Basin and control in the Cooper and Eromanga Basins, South Australia. Exploration Geophysics, 28(3), pp-333-339.

Sutherland, F.L., 1978. Mesozoic-Cainozoic volcanism of Australia. Tectonophysics, 48(3-4), pp-4I3427.

Sutherland, F.L., Graham, I.T., Hollis, J.D., Meffre, S., Zwingmann, H., Jourdan, F. \& Pogson R.E., 2014. Multiple felsic events within post-10 Ma volcanism, Southeast Australia: inputs in appraising proposed magmatic models. Australian Journal of Earth Sciences, 16, 24I- 267.

Tang, Y., Obayashi, M., Niu, F., Grand, S.P., Chen, Y.J., Kawakatsu, H., Tanaka, S., Ning, J. and Ni, J.F., 2014. Changbaishan volcanism in northeast China linked to subduction-induced mantle upwelling. Nature Geoscience, 7(6), pp.470-475

Tappert, R., Foden, J., Stachel, T., Muehlenbachs, K., Tappert, M. and Wills, K., 2009. Deep mantle diamonds from South Australia: A record of Pacific subduction at the Gondwanan margin. Geology, 37(H), pp.43-46.

Tarling, D.H., 1966. The magnetic intensity and susceptibility distribution in some Cenozoic and Jurassic basalts. Geophysical Journal International, I I (4), pp.423-432. 
Thomson, K., and Schofield, N.. "Lithological and structural controls on the emplacement and morphology of sills in sedimentary basins." Geological Society, London, Special Publications 302.I (2008): 31-44.

Tracey R, Bacchin M, \& Wynne P., 2008, In preparation. AAGD07: A new absolute gravity datum for Australian gravity and new standards for the Australian National Gravity Database.

Exploration Geophysics.

Trude, J., Cartwright, J., Davies, R.J. and Smallwood, J., 2003, New technique for dating igneous sills, Geology, v. 3 I, p. $-813-816$.

Tucker, R.T., Roberts, E.M., Henderson, R.A. and Kemp, A.I., 2016, Large igneous province or longlived magmatic arc along the eastern margin of Australia during the Cretaceous? Insights from the sedimentary record, Geological Society of America Bulletin, v. I 28, p. | 46 I-I 480.

Veevers, J.J. and Conaghan, P.J., 1984, Phanerozoic earth history of Australia, Oxford University Press, USA.

Wainman, C.C., Mccabe, P.J., Crowley, J.L. and Nicoll, R.S., 20I5, U-Pb zircon age of the Walloon Coal Measures in the Surat Basin, southeast Queensland: implications for paleogeography and basin subsidence, Australian Journal of Earth Sciences, $\vee .62$, p. 807-816.

Wainman, C.C., Reynolds, P., Hall, T., McCabe, P.J. and Holford, S.P., 2019. Nature and origin of tuff beds in Jurassic strata of the Surat Basin, Australia: Implications on the evolution of the eastern margin of Gondwana during the Mesozoic. Journal of Volcanology and Geothermal Research.

Warren, A.Y.E., Barron, L.M., Meekin, N.S., Morgan, E.J., Raymond, O.L., Cameron, R.G. \& Colquhoun, G.P., 1999. Mesozoic Igneous Rocks. In Meakin, N.S. \& Morgan, E.J. (Compilers). Dubbo I:250 000 Geological Sheet SI/55-4, 2nd edition, Explanatory Notes, PP. 313-328. Geological Survey of New South Wales, Sydney. Watson, D., Schofield, N., Jolley, D., Archer, S., Finlay, A.J., Mark, N., Hardman, J. and Watton, T., 2017. Stratigraphic overview of Palaeogene tuffs in the Faroe-Shetland Basin, NE Atlantic Margin. Journal of the Geological Society, I74(4), pp.627-645.

Watts, K.J., 1987, The Hutton Sandstone-Birkhead Formation Transition, ATP 269P(I), The APEA Journal, Volume 27 Number I, p-2I5 - 228.

White, J.D. and Ross, P.S., 2011. Maar-diatreme volcanoes: a review. Journal of Volcanology and Geothermal Research, 201, 1-29.

Yew, C.C. and Mills, A.A., 1989. The occurrence and search for Permian oil in the Cooper Basin, Australia. 
1170 Zhou, Q., Liu, L. and Hu, J., 2018, Western US volcanism due to intruding oceanic mantle driven by ${ }_{2}^{1} 1171$ ancient Farallon slabs, Nature Geoscience, v. II, p.70.

3

41172

5

6

7

8

9

10

11

12

13

14

15

16

17

18

19

20

21

22

23

24

25

26

27

28

29

30

31

32

33

34

35

36

37

38

39

40

41

42

43

44

45

46

47

48

49

50

51

52

53

54

55

56

57

58

59

60

61

62

63

64

65 
12. Tables

\begin{tabular}{|l|l|l|l|l|}
\hline Seismic Survey & $\begin{array}{l}\text { Acquisition } \\
\text { Date }\end{array}$ & $\begin{array}{l}\text { Acquisition } \\
\text { Company }\end{array}$ & Areal Coverage & Data Type \\
\hline Winnie & 2012 & $\begin{array}{l}\text { Drillsearch Energy } \\
\text { Ltd. And } \\
\text { WesternGeco }\end{array}$ & $1050 \mathrm{~km}^{2}$ & $3 \mathrm{D}$ \\
\hline Snowball & 2016 & Santos Ltd. & $1698 \mathrm{~km}^{2}$ & $3 \mathrm{D}$ \\
\hline Gallus & 2012 & $\begin{array}{l}\text { Beach Energy and } \\
\text { Icon Energy }\end{array}$ & $420 \mathrm{~km}$ & $2 \mathrm{D}$ \\
\hline Madigan & 1996 & Santos Ltd. & $584 \mathrm{~km}^{2}$ & $3 \mathrm{D}$ \\
\hline
\end{tabular}

Table I: List of the seismic surveys that were determined to contain igneous rocks and utilised within this study.

\begin{tabular}{|l|l|l|l|}
\hline Location of Igneous Rocks & Name & Age & Key Reference \\
\hline Marion Platea & $\mathrm{n} / \mathrm{a}$ & Jurassic & Isern et al., 2002 \\
\hline Eastern Highlands and Sydney Basin & $\mathrm{n} / \mathrm{a}$ & $235-46.9 \mathrm{Ma}$ & Pells, I985 \\
\hline Gunnedah Basin & Garawilla Basalts & $195-141 \mathrm{Ma}$ & Gurba \& Weber, 200I \\
\hline New South Wales & Dubbo Volcanics & $236-170 \mathrm{Ma}$ & Warren et al., I999 \\
\hline Eastern Victoria & $\mathrm{n} / \mathrm{a}$ & $191-179 \mathrm{Ma}$ & Elburg \& Soesoo, I999 \\
\hline Tasmania & $\mathrm{n} / \mathrm{a}$ & $183-182 \mathrm{Ma}$ & Ivanov et al., 20I7 \\
\hline Kangaroo Island & Wisanger Basalt & $170 \mathrm{Ma}$ & Milnes et al., I982 \\
\hline
\end{tabular}

Table 2: List of Cretaceous igneous rocks in Eastern Australia. Where possible, a name and age range has been given. Each location is discussed within the text. 

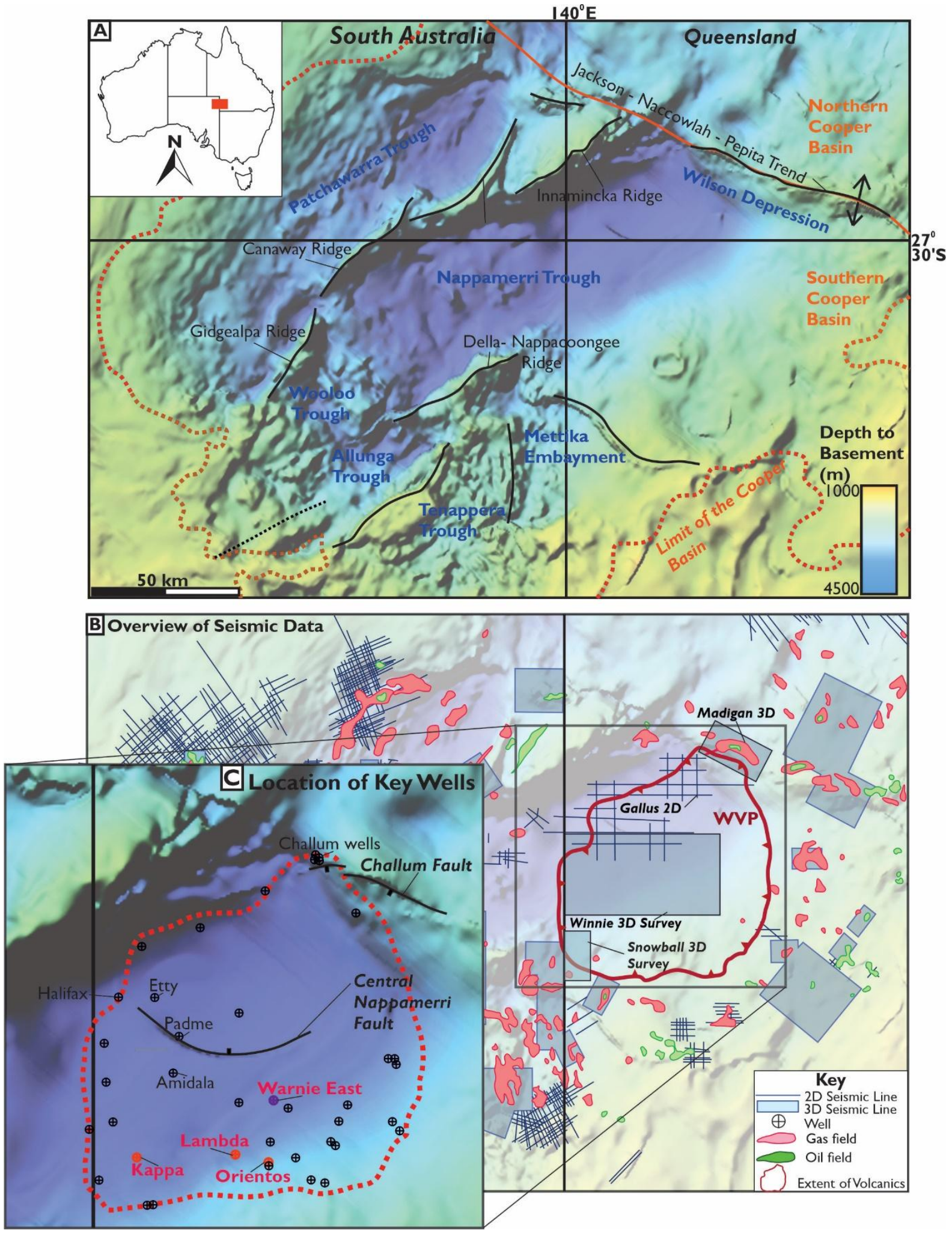

Figure I. Location map of the Warnie Volcanic Province and the data available. A Top basement map adapted from the SA Department for Manufacturing, Innovation, Trade, Resources and Energy (2003). Key structures of the southern Cooper Basin highlighted. B Location map highlighting the 
1185 location of the Warne Volcanic Province within the Cooper Basin. Top basement map superimposed ${ }_{2}^{1} 1186$ with the location of 3D and 2D seismic surveys utilised in this study and the location of key 31187 exploration wells. C Location map of the wells drilled within the Warnie Volcanic Province that 4 were analysed during this study. Wells that intersected igneous rocks are highlighted in red. The locations of the Central Nappamaerri Fault and the Challum Fault, structures discussed in the text, are noted. 
1

2

3

4

5

6

7

8

9

10

11

12

13

14

15

16

17

18

19

20

21

22

23

24

25

26

27

28

29

30

31

32

33

34

35

36

37

381193

39

401194

41

421195

43

441196

451197

471198

48

49

501199

51

52

53

54

55

56

57

58

59

60

61

62

63

64

65

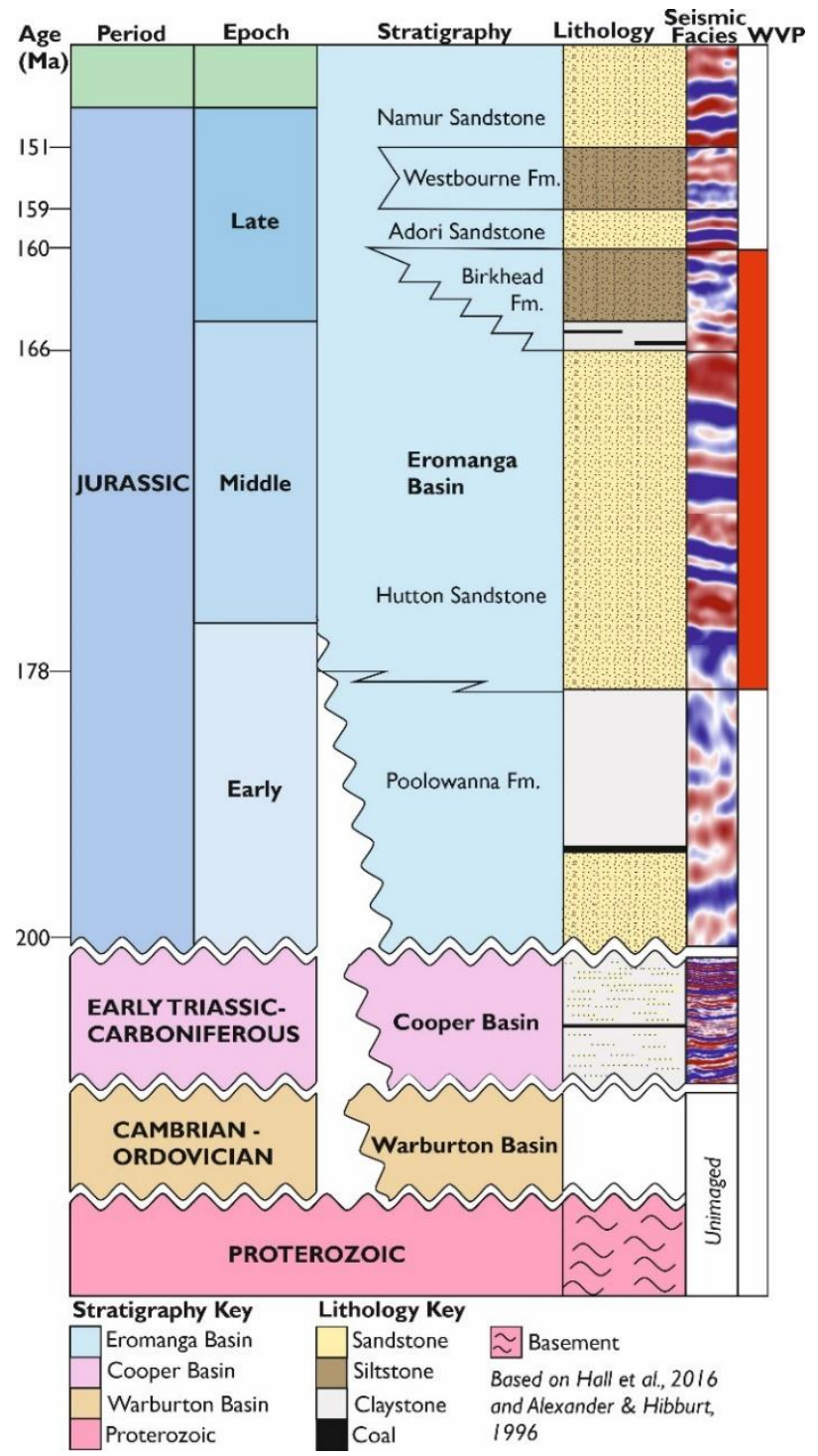

Figure 2. Stratigraphic column for the stratigraphy discussed within the paper, based on the work of Alexander \& Hibburt (1996), Hall et al. (2016) \& Reid et al. (2009). Seismic facies for each section is taken from the Winnie 3D survey of the eastern Nappamerri Trough. Rough stratigraphic location of the WVP highlighted. 


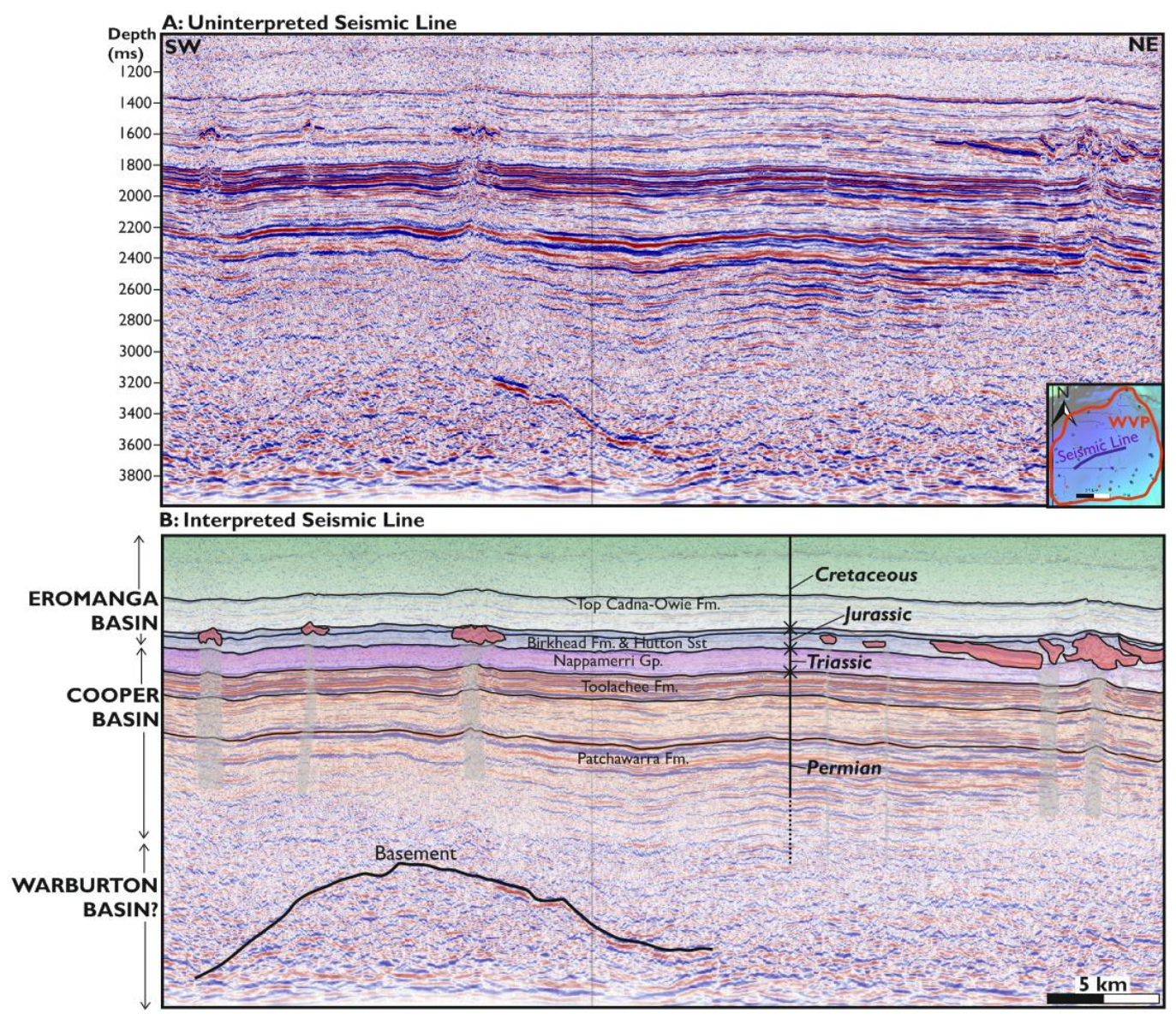

Figure 3. Seismic line from the Winnie 3D survey of the Nappamerri Trough highlighting the broad stratigraphy of the study area. A Uninterpreted line. B Interpreted line. Note the stacked nature of the Eromanga, Cooper and Warburton Basins and the stratigraphic location of the Warne Volcanic Province. 

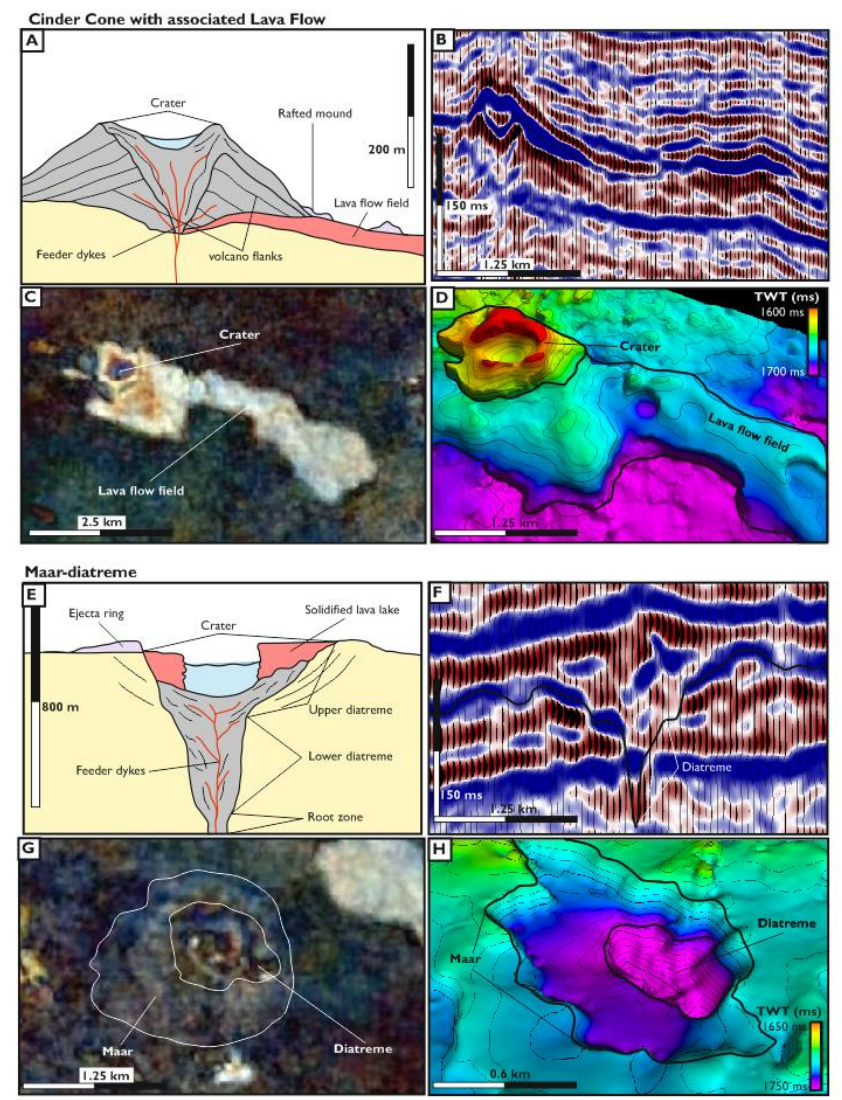

Figure 4. Examples of different monogenetic vents. A Cross section through a cinder cone, adapted from Németh \& Kereszturi (2015). B Seismic line across a cinder cone and lava flow, taken from the Winnie 3D survey, highlighting the general morphology, seismic response. Note the characteristic eye shape within the centre of the vent. C Plan view spectral decomposition of the cinder cone in B highlighting how different it is from the surrounding sediments. D Oblique view of the same cinder cone shown in TWT. E Cross section through a Maar-diatreme, adapted from Németh \& Kereszturi (20I5). F Seismic line across a proposed Maar-diatreme from the Winnie 3D survey. Note how it cuts down into the subsurface with an internally chaotic seismic response. G Plan view spectral decomposition of the Maar-diatreme within the Winnie 3D survey. $\mathbf{H}$ Oblique, TWT view of the proposed Maar-diatreme. 


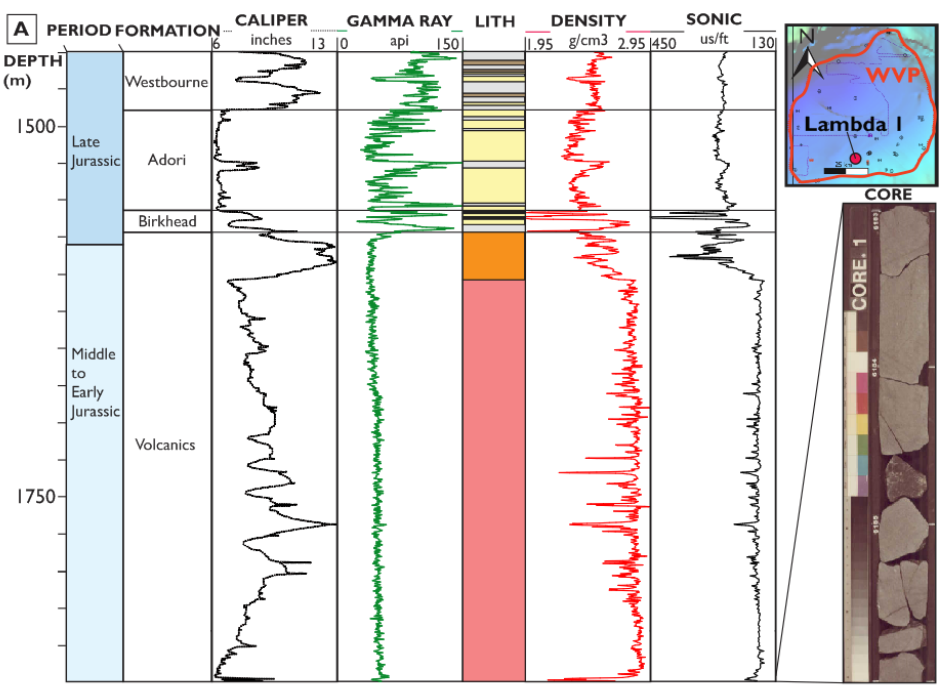

Figure 5. Well data for the volcanics from the Lambda-I well. A Composite log of the volcanic succession in the Lambda-I well. Includes an image of the core taken from the base of the volcanic successon. B Vitrinite reflectance curve for the succession above the volcanics taken from Boothby (1986). Little thermal effect is observed. C Velocity histogram of the Lambda-I volcanics superimposed on Nelson et al.'s (2009) velocity histogram of Tabular basalt. 
1

2

3

4

5

6

7

8

9

10

11

12

13

14

15

16

$17^{1226}$

18

191227

201228

21

22

231229

24

251230

26

27

$28^{1231}$

29

301232

31

32

331233

34

35

36

37

38

39

40

41

42

43

44

45

46

47

48

49

50

51

52

53

54

55

56

57

58

59

60

61

62

63

64

65

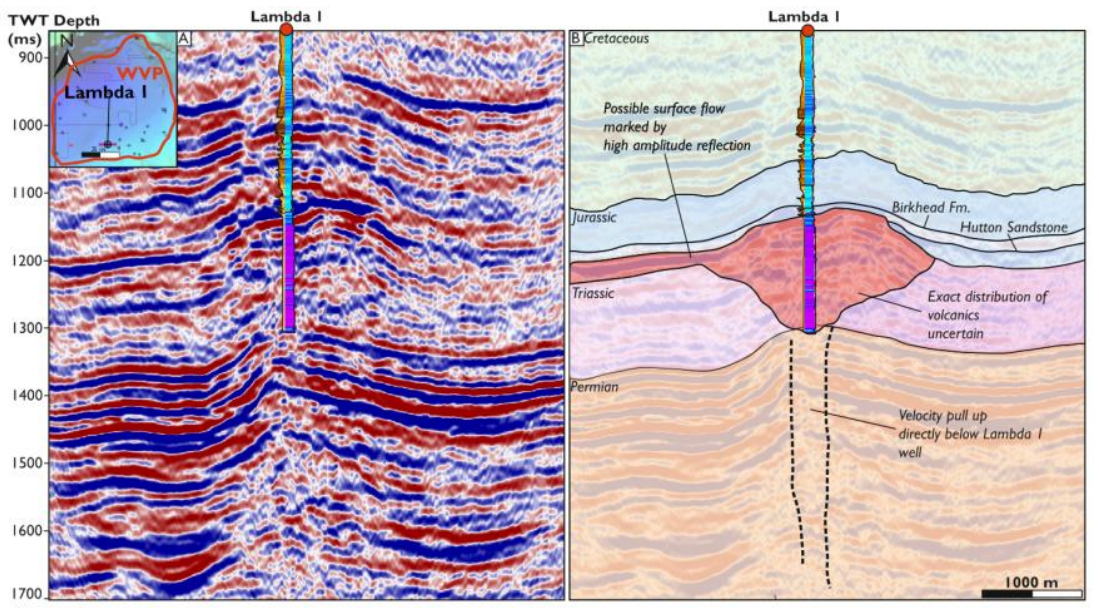

Figure 6. West to east seismic line running across the Lambda I well. The extent of the Lambda I vent has been inferred base on the thickness of volcanics within the well. 
1

2

3

4

5

6

A) Spectral Decomposition of Winnie 3D Volcanics

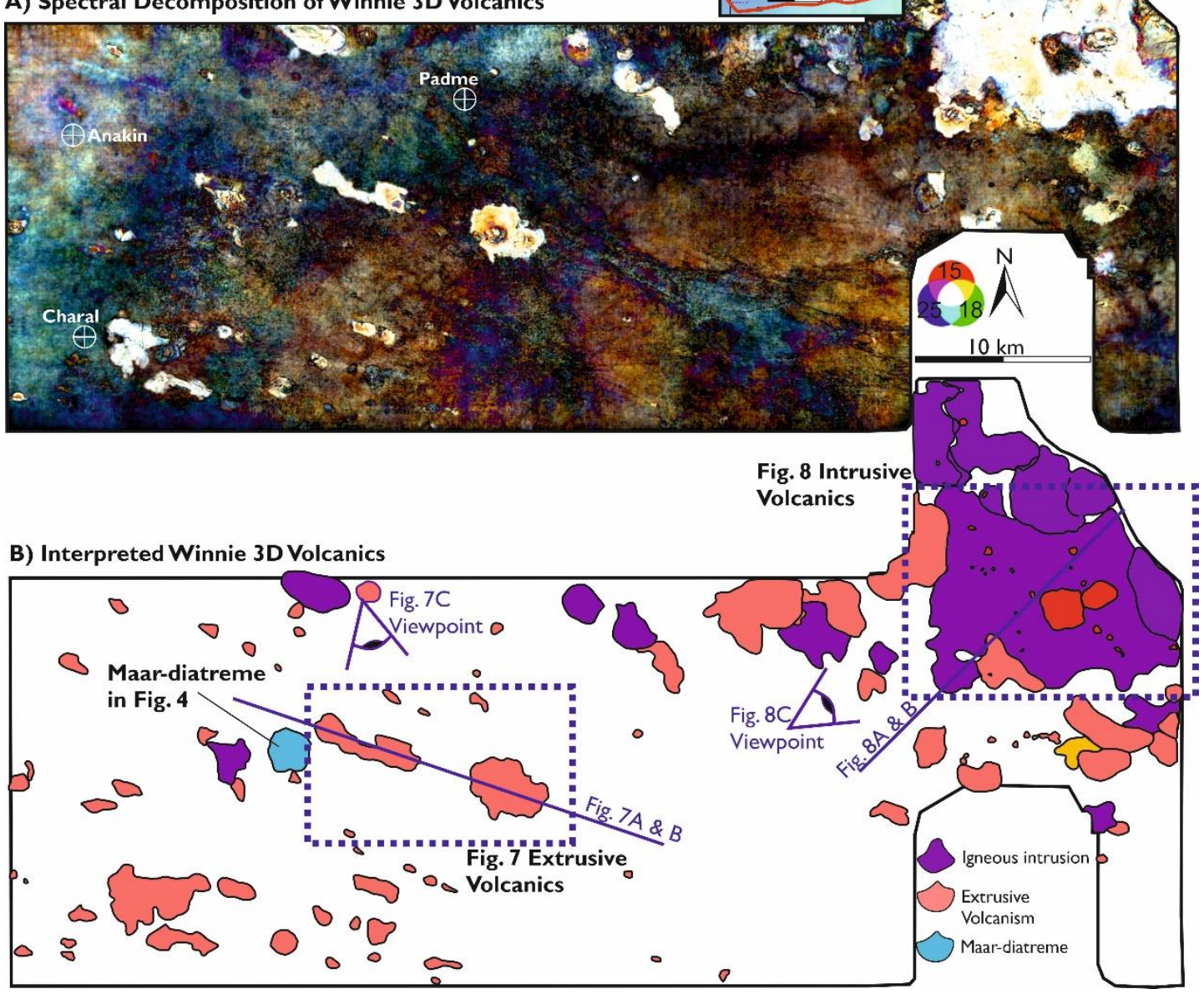

Figure 7. Spectral decomposition of a horizon mapped across the volcanics of the Winnie 3D survey. A Uninterpreted spectral decomposition. B Interpreted spectral decomposition highlight extrusive volcanics and the location of igneous intrusions. Note the increased number of intrusions towards the north east of the Winnie 3D survey. 

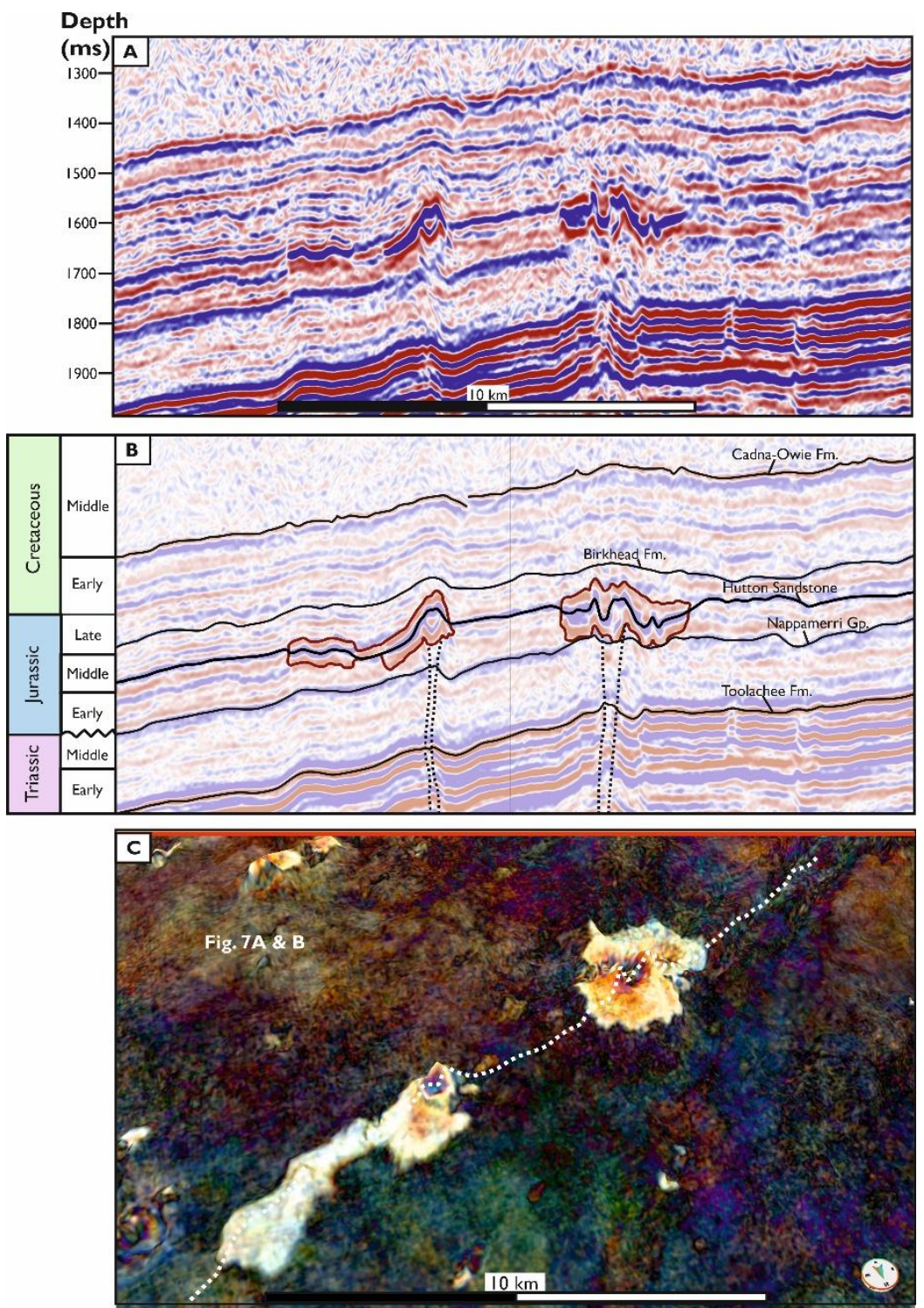

Figure 8. 3D Seismic across two monogenetic vents that extend into surface flows, from the Winnie 3D survey. A Uninterpreted line across the vents. B Interpreted line across the vents. Note the vertical zone of disrupted seismic directly below the vents, indicative of underlying plumbing system that fed the flows. C Spectral decomposition of a horizon mapped across the vents, highlighting their 3D morphology. 


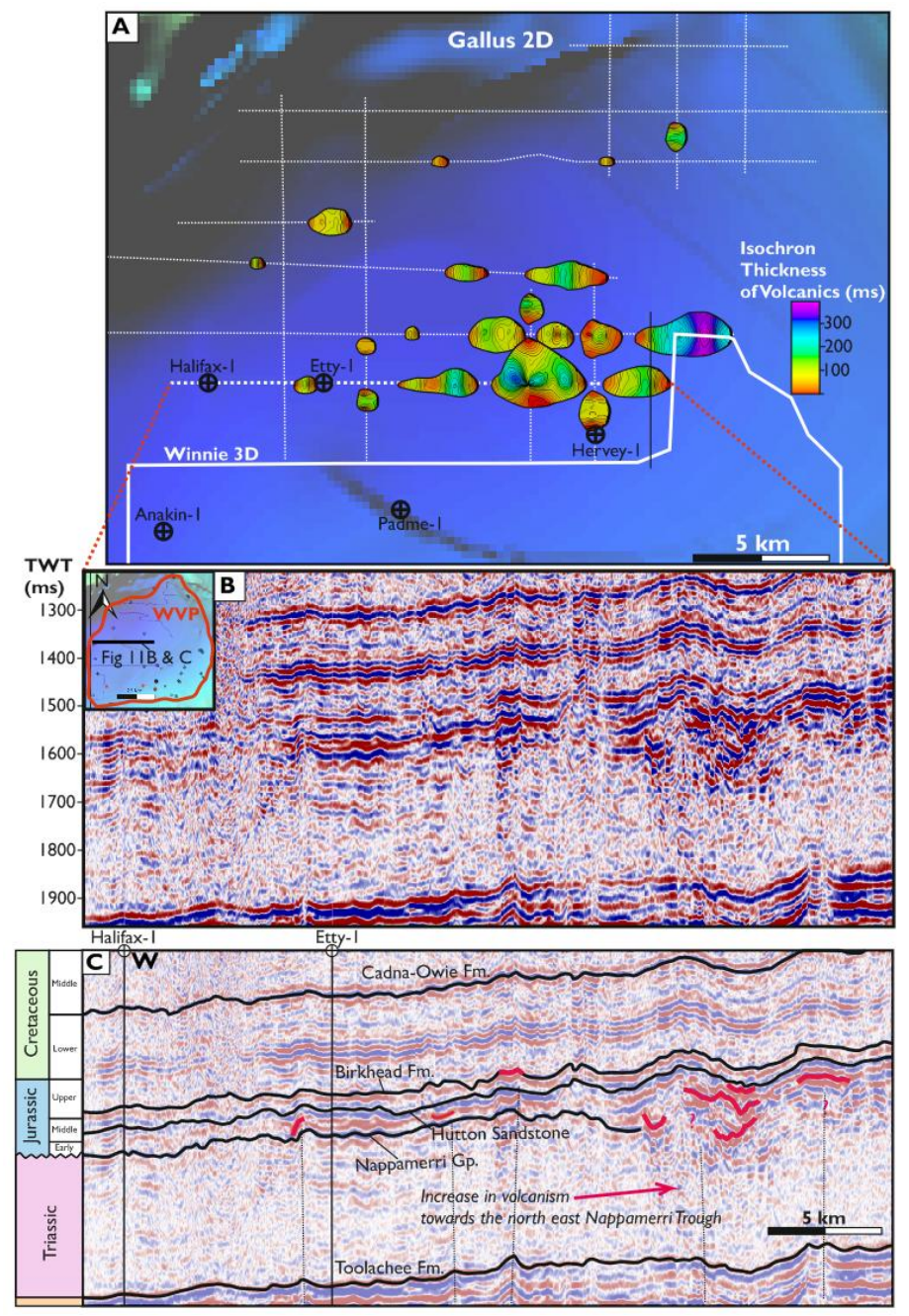

Figure 9. Seismic images of the Gallus 2D survey. A Isochron thickness map of the volcanics identified throughout the Gallus 2D survey. B Uninterpreted seismic line from the Gallus 2D survey. C Interpreted seismic line from the Gallus 2D survey. An increase in the volume of volcanics towards the east of the survey is apparent. 
1

2

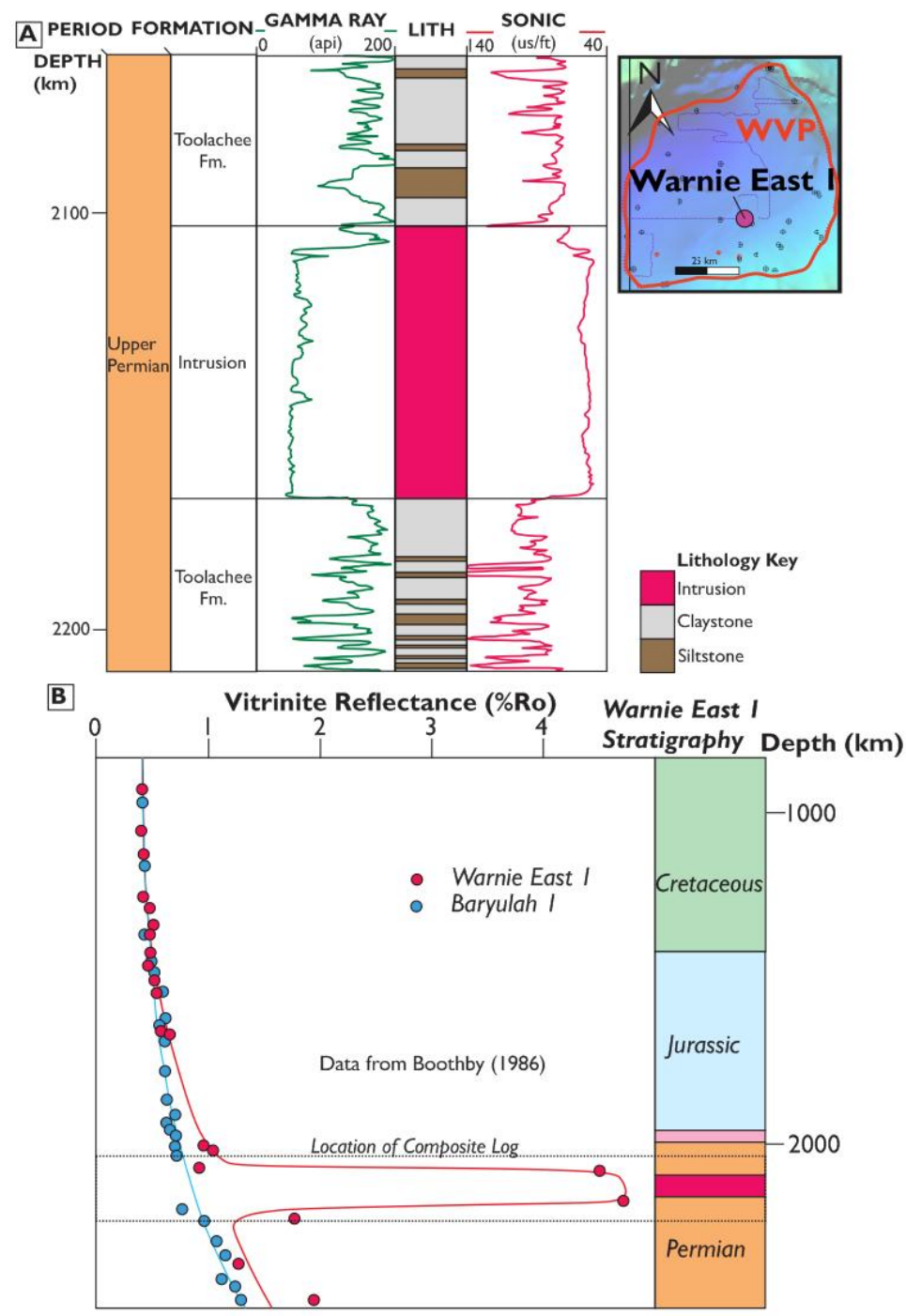

Figure 10. Well data for intrusive volcanic rocks within the Warnie East I well. A Composite log across the intrusion in the Warnie East well. B Vitrinite reflectance profile across the intrusion in the Warnie East well taken from Boothby (1986). Thermal effect both above and below the well is noted. 


\section{TWT Depth}

Warnie East I
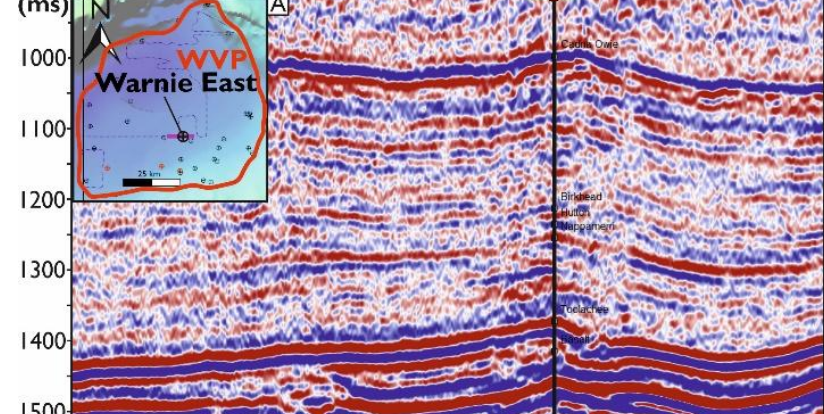

$$
1500
$$

1600

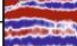

1700

1800

1900

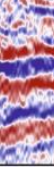

Figure II. 2D seismic line running from west to east across the Warnie East I well. The exact location of the igneous rocks is unclear on the line, however, a shallow saucer-shaped reflection with the Toolachee Fm. intersects Warnie East I at the depth igneous rocks are found. The lack of clearly imaged igneous rocks could point to more unimaged intrusive igneous rocks within the Cooper Basin succession.
Warnie East I

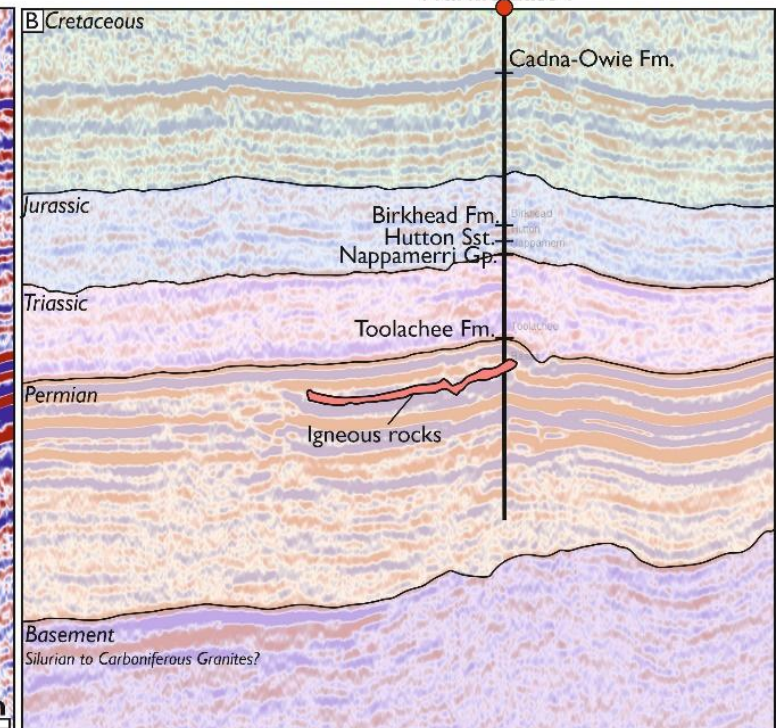

\section{Basin succession.}




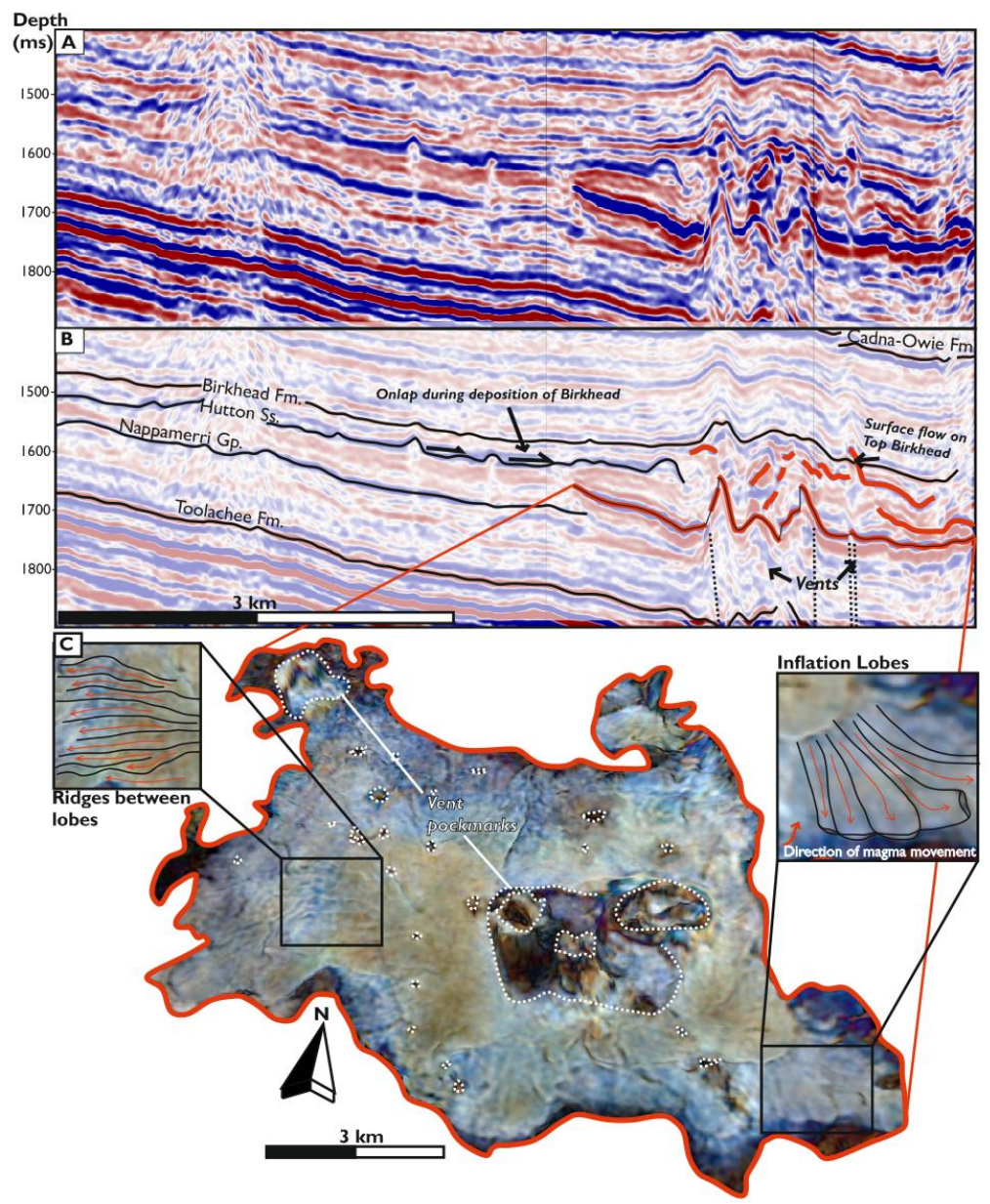

Figure 12. Seismic across the large intrusion in the Winnie 3D survey. A Uninterpreted seismic line. B Interpreted seismic line, illustrating the uplift of the overburden and the numerous vents and overlying volcanics associated with the intrusion. C Spectral decomposition of the intrusion, highlight the pockmarks of vents that pass through the intrusion and morphological characteristics associated with the intrusion. 
1

2

3

4

5

6

7

8

9

10

11

12

13

14

15

16

17

18

19

20

21

22

23

24

25

26

27

28

29

30

31

32

33

34

35

36

37

381276

39

401277

41

421278

43

441279

45

46

47

48

49

50

51

52

53

54

55

56

57

58

59

60

61

62

63

64

65

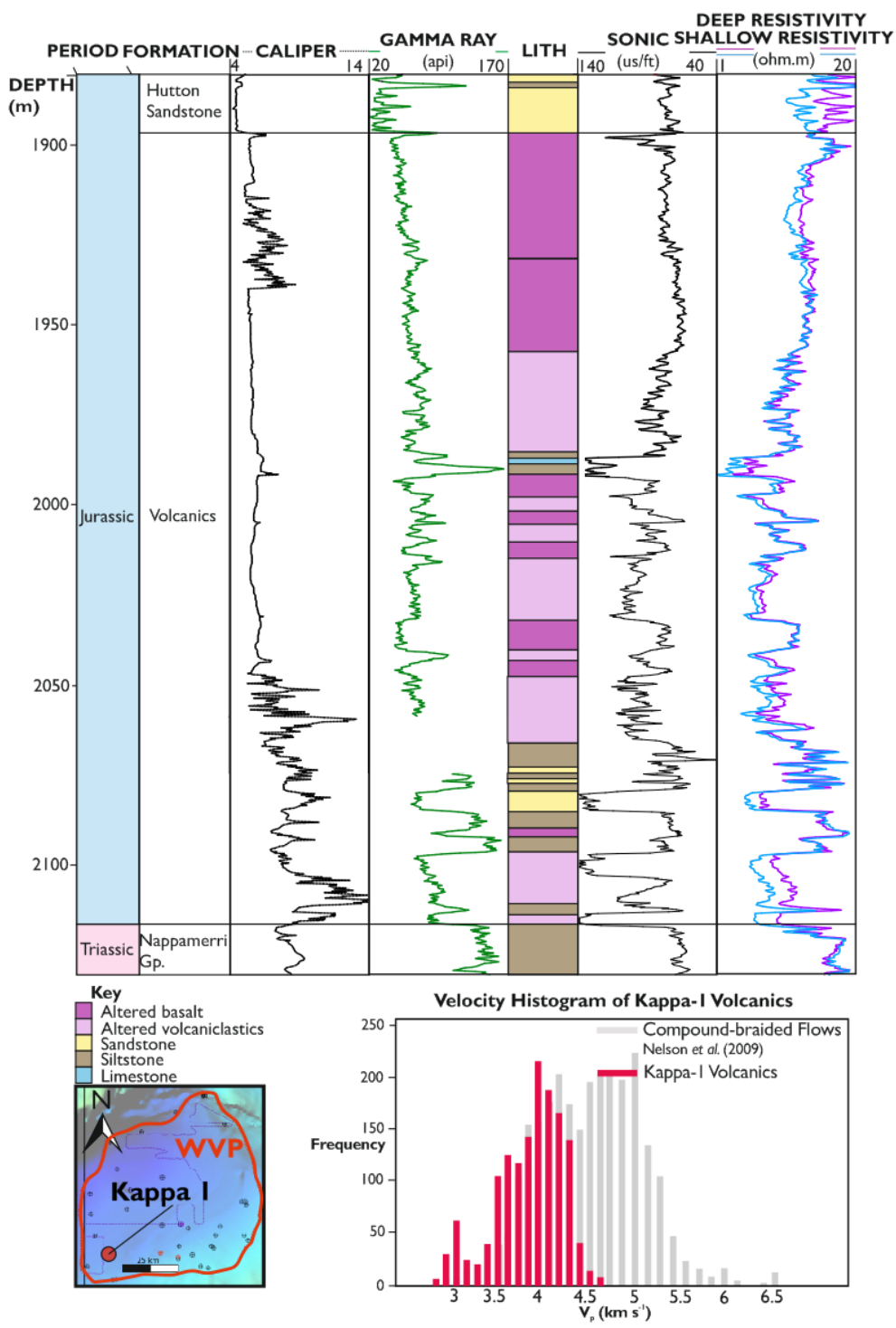

Figure 13. Well data for the Kappa-I well. A Composite log for the Kappa-I well volcanics. B Velocity histogram for the Kappa-I well volcanics, superimposed on top of Nelson et al.'s (2009) velocity histogram for compound-braided volcanics. 


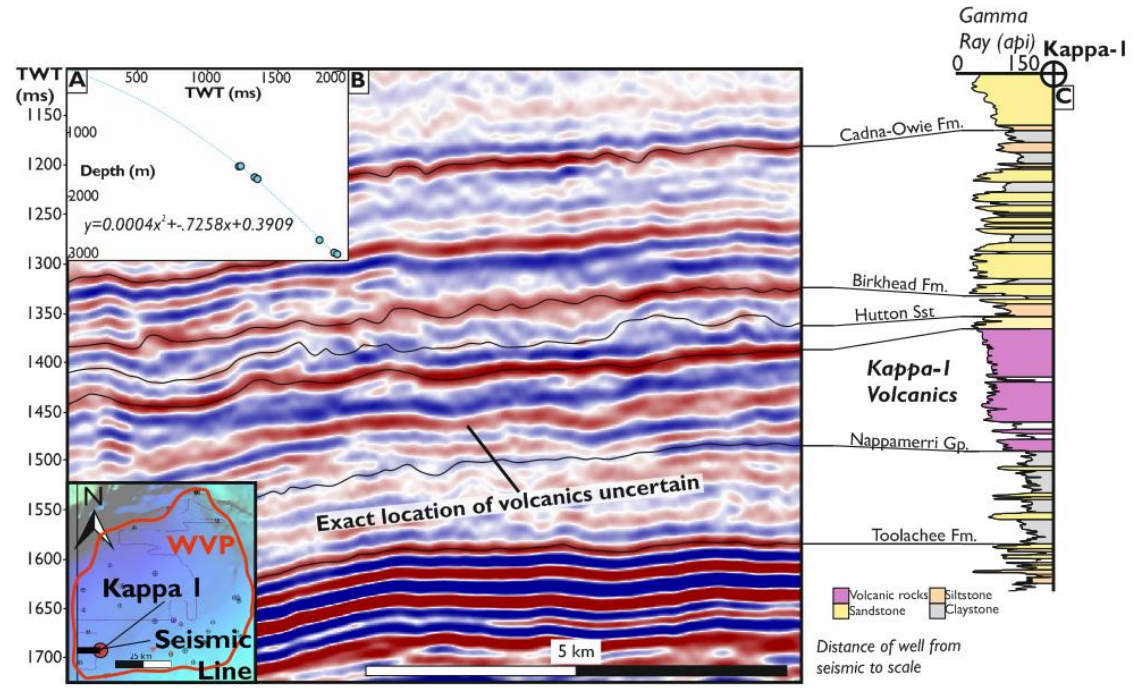

Figure 14. Position of the Kappa-I well in relation to the Snowball 3D survey. A Pseudo TWT/depth plot that was created using the velocity data synthesised for the wells drilled within the central Nappamerri Trough (namely Halifax, Etty, Anakin, Padme, Charal). This TWT to depth relationship was used to convert the Kappa-I well data from depth to time in order to display it adjacent to the Snowball 3D survey. B Line across the Snowball 3D survey with the position of formation tops based on the Kappa-I well displayed. C Gamma ray curve from the Kappa-I well with formation tops marked. 

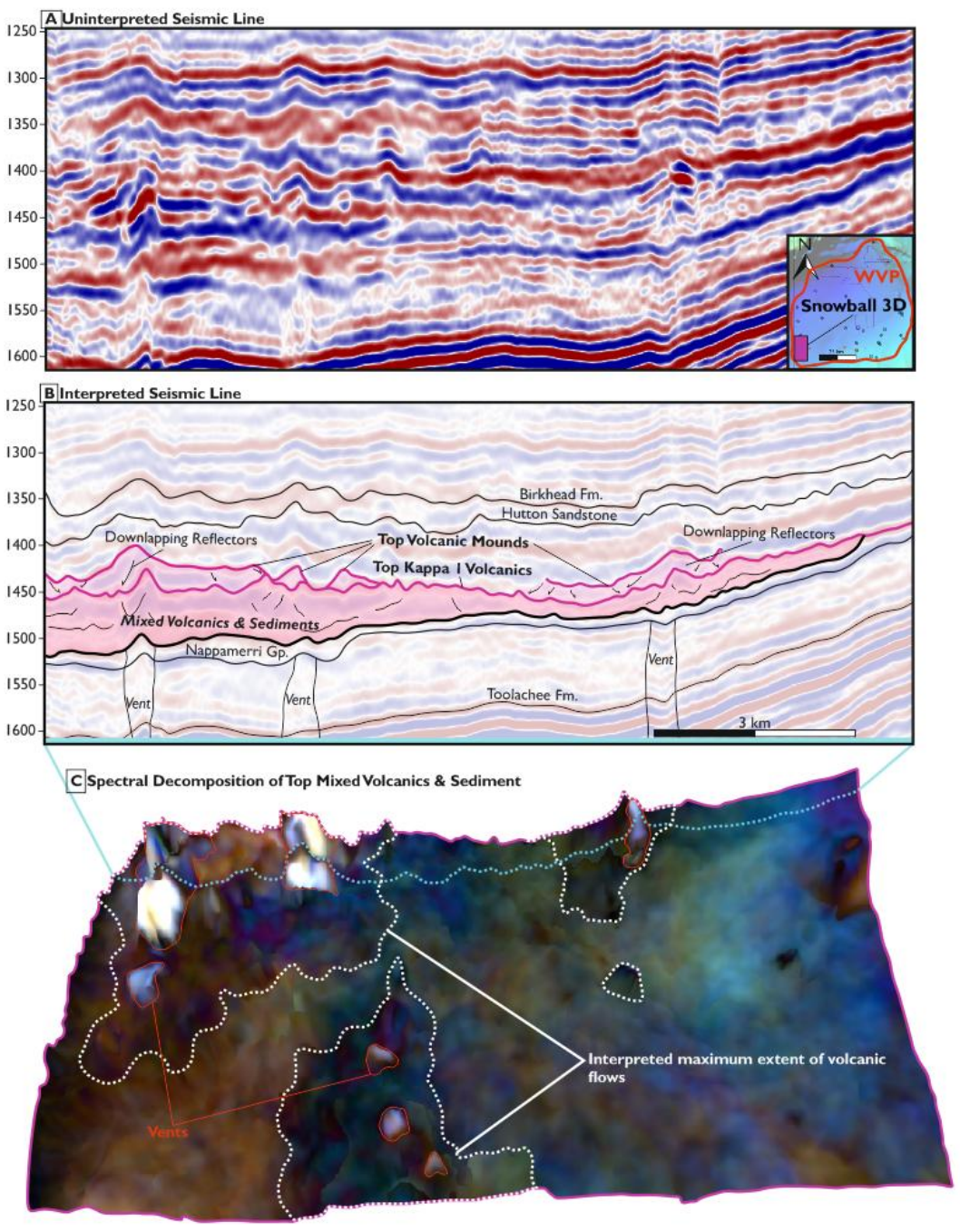

Figure I5. Seismic across volcanics within the Snowball 3D survey. A Uninterpreted seismic line. B Interpreted seismic line. Thick package of mixed volcanics \& sediments based off of the Kappa-I well volcanics. C Spectral decomposition of the top mixed volcanics \& sediment horizon. Location of vents noted by bright white colour with interpreted flow fields based on the cohesive dark colours extending away from the vents. 

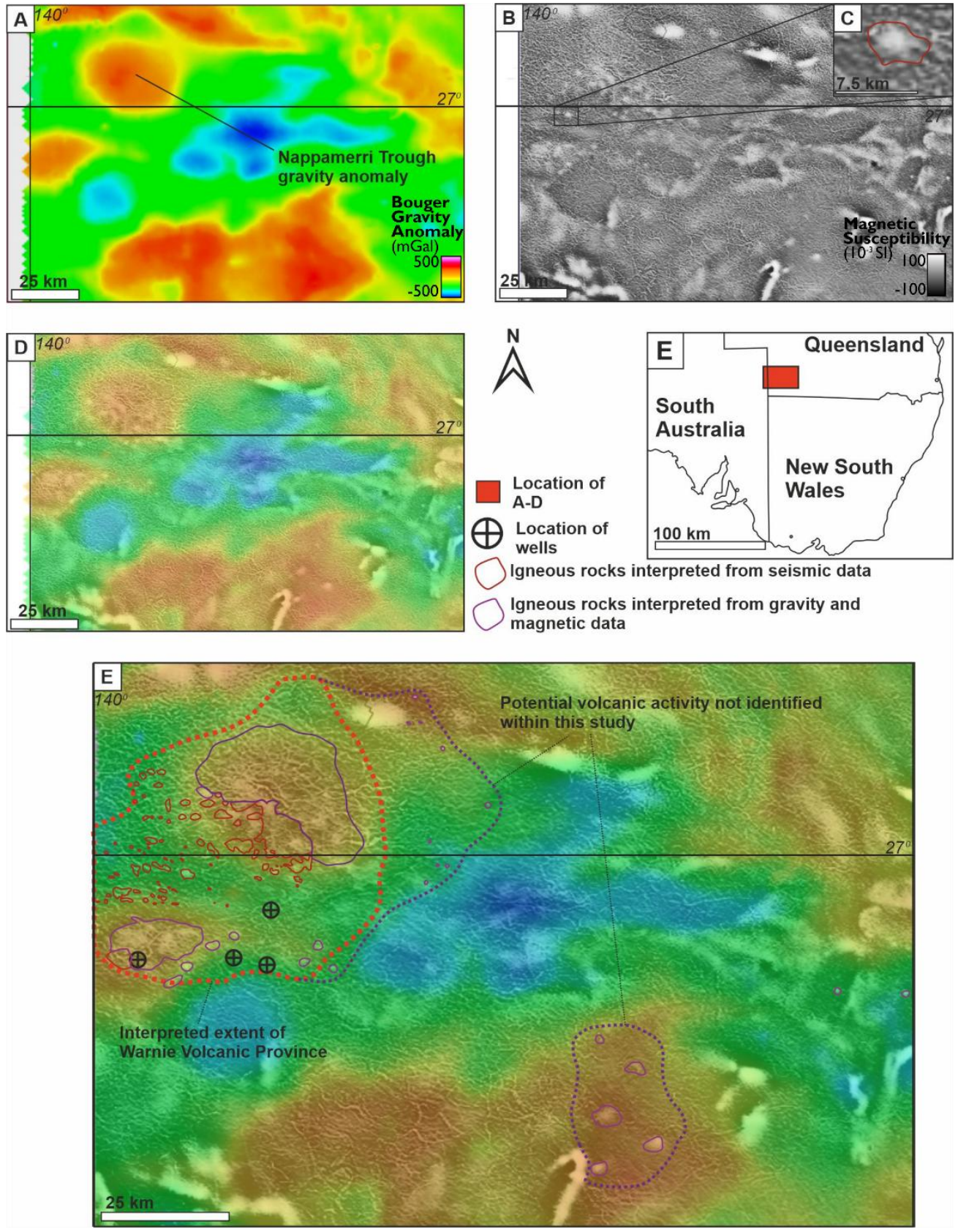

Figure 16. Regional geophysical surveys adopted from the Queensland Government's data anomaly highlighted. B Uninterpreted IVD magnetic data. C Inset of B showing a $\sim 6 \times 5 \mathrm{~km}$ gravity magnetic anomaly with the interpreted extent of igneous rocks identified using seismic data superimposed on top of the anomaly. D Uninterpreted image of the gravity data set to $50 \%$ transparency overlain on top of the IVD magnetic data. E Interpreted image of the combined gravity/IVD magnetic data. The extent of the Warnie Volcanic Province interpreted using well and seismic data within this study is indicated. Areas with circular magnetic anomalies and high gravity signatures not identified using well or seismic data are also highlighted. These areas could represent further igneous rocks within the SW Queensland. 


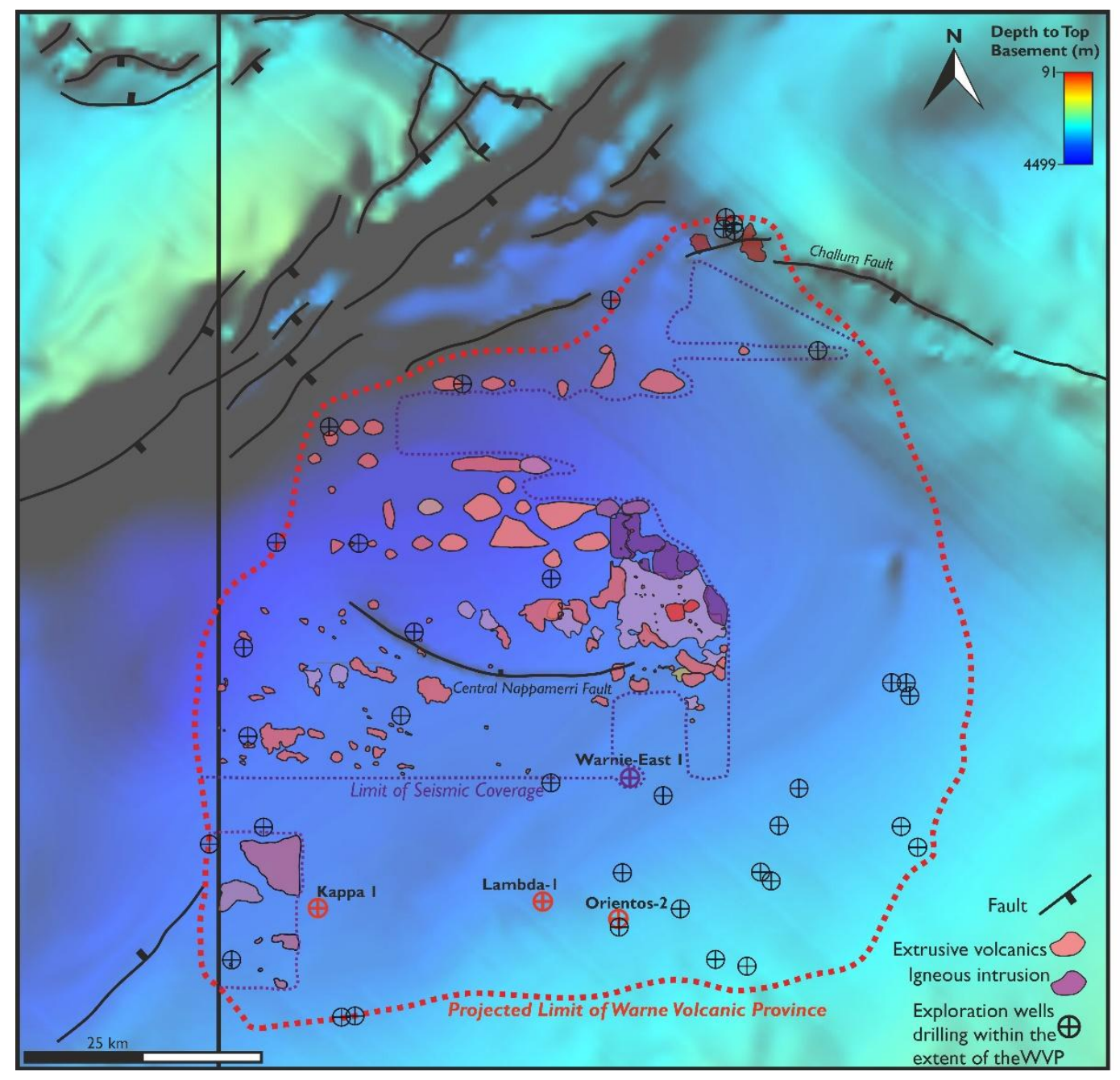

Figure 20: Regional map of the Warnie Volcanic Province. Depth to top basement map adapted from SA Department for Manufacturing, Innovation, Trade, Resources and Energy (2003). Location of extrusive volcanics and igneous intrusions based on seismic data. The igneous rocks, however, are thought to extend beyond the limit of seismic coverage towards the projected limit of the Warnie Volcanic Province. 
A) Location of Vents Intersecting Top Toolachee Reflection
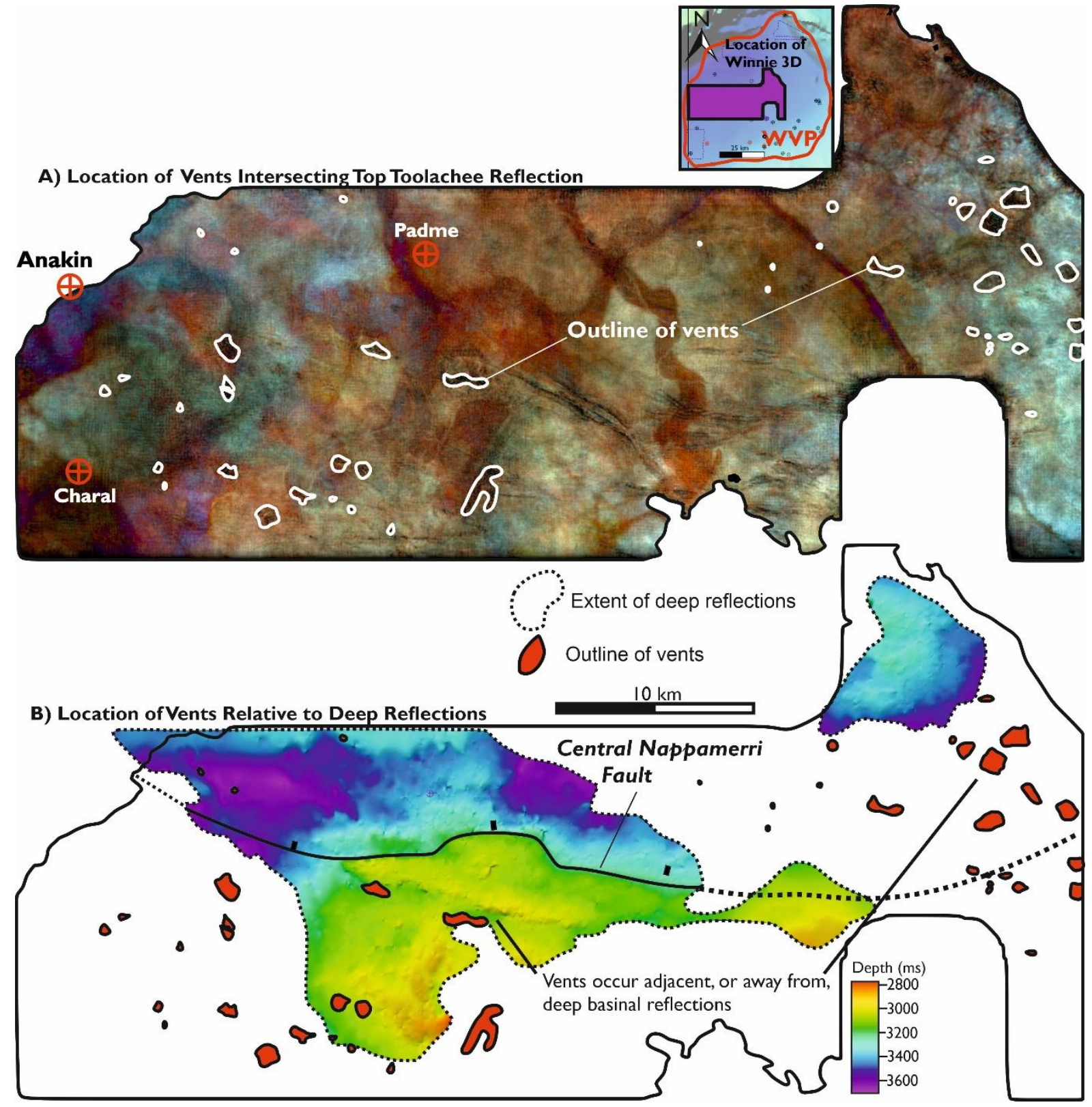

B) Location of Vents Relative to Deep Reflections

$10 \mathrm{~km}$

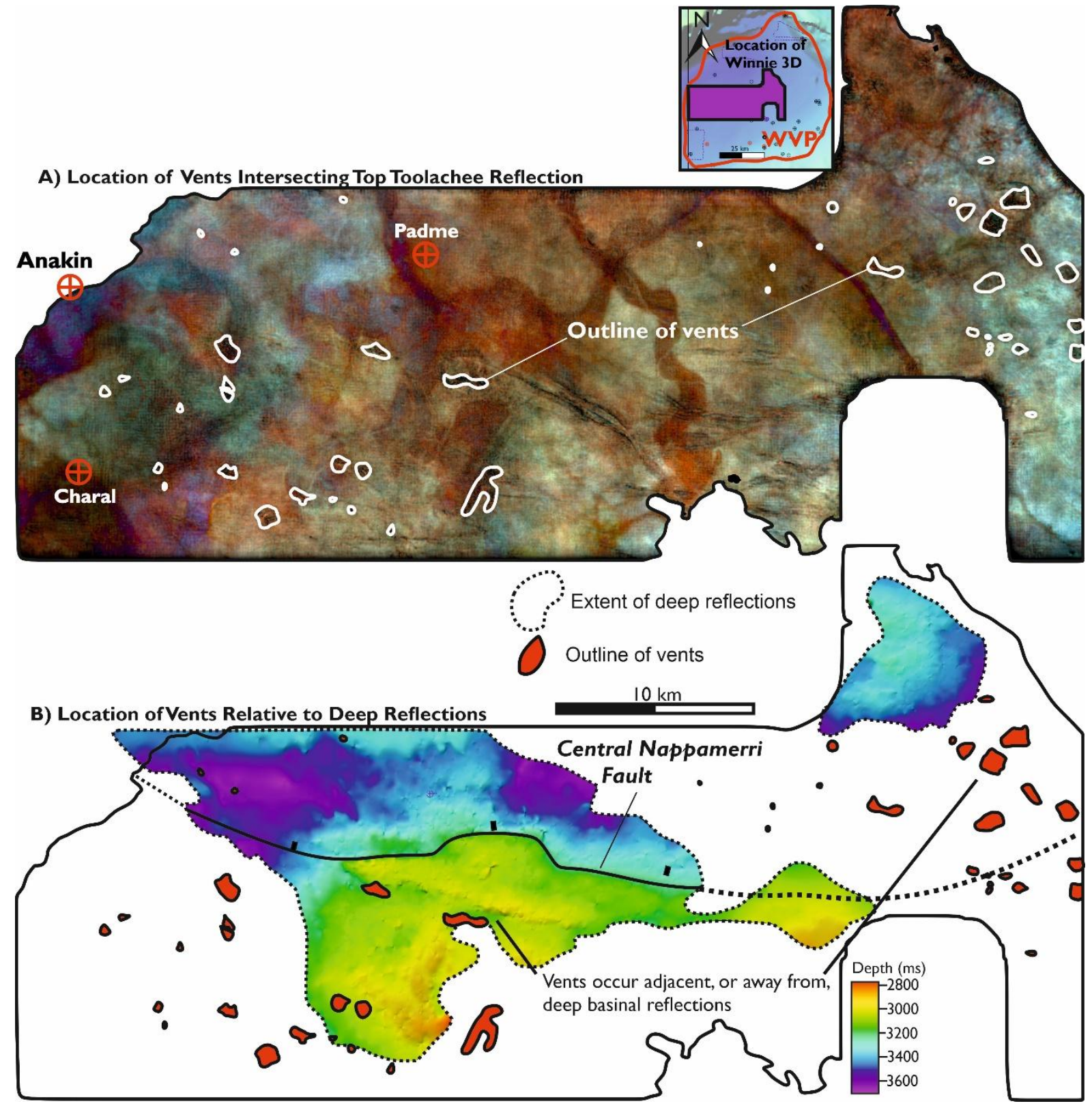

Figure 17. The basement structure and it's relation to vents within the Winnie 3D survey. A Spectral decomposition of the Top Toolachee horizon, highlighting the location of vents underlying the WVP. B Location of vents mapped using the Top Toolachee horizon superimposed on a TWT map of the top basement horizon. Many of the vents sit away from shallow basement reflections. Two vents are situated directly above the Central Nappamerri Fault. Two vents are situated directly above the Central Nappamerri Fault. 

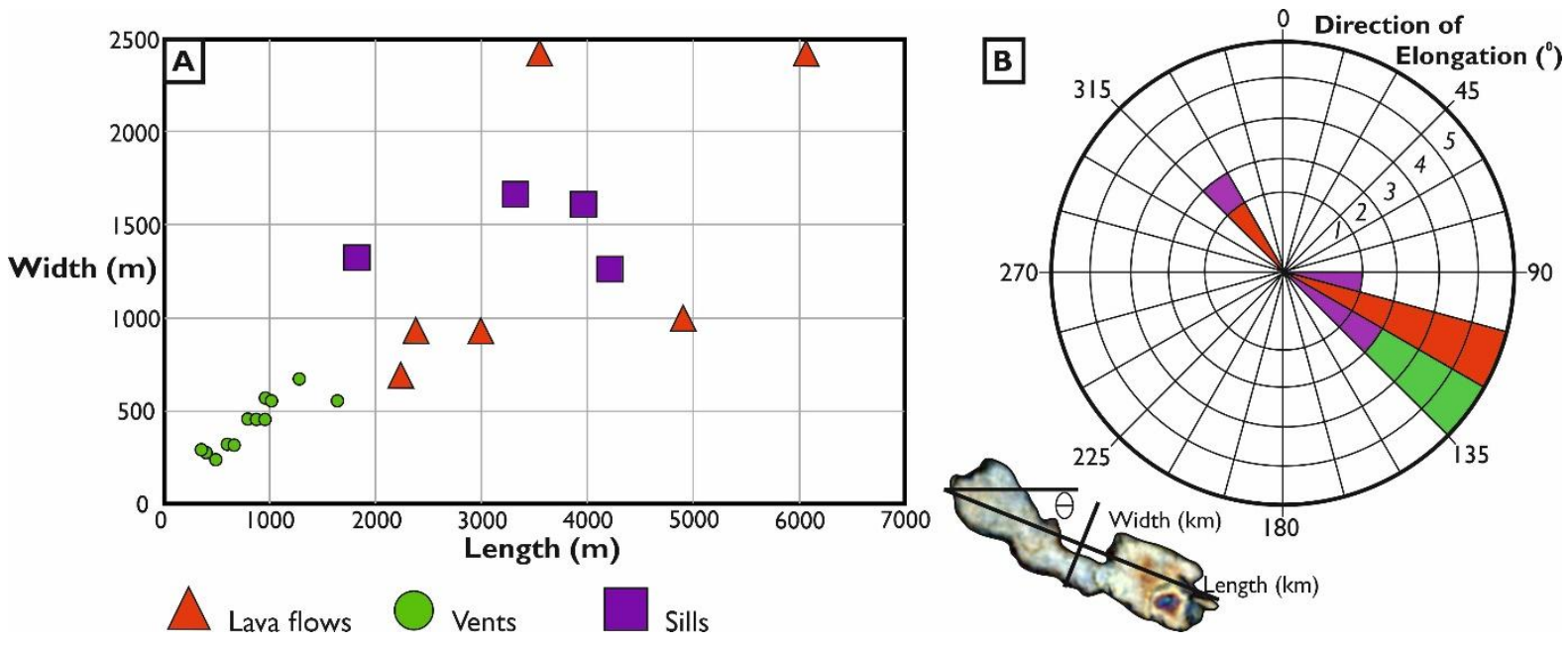

Figure 18: Size and orientation of volcanics within the Winnie 3D and Madigan 3D surveys. A Size of vents, intrusions and volcanic flows. Note, the large Winnie 3D intrusion has not been included on this figure due to its sheer scale (dimensions of $8 \mathrm{~km} \times 14 \mathrm{~km}$ ) compared to the rest of the Warnie Volcanic Province. B Direction of elongation for the igneous rocks, highlighting that they are elongate in a SE-NW direction. 


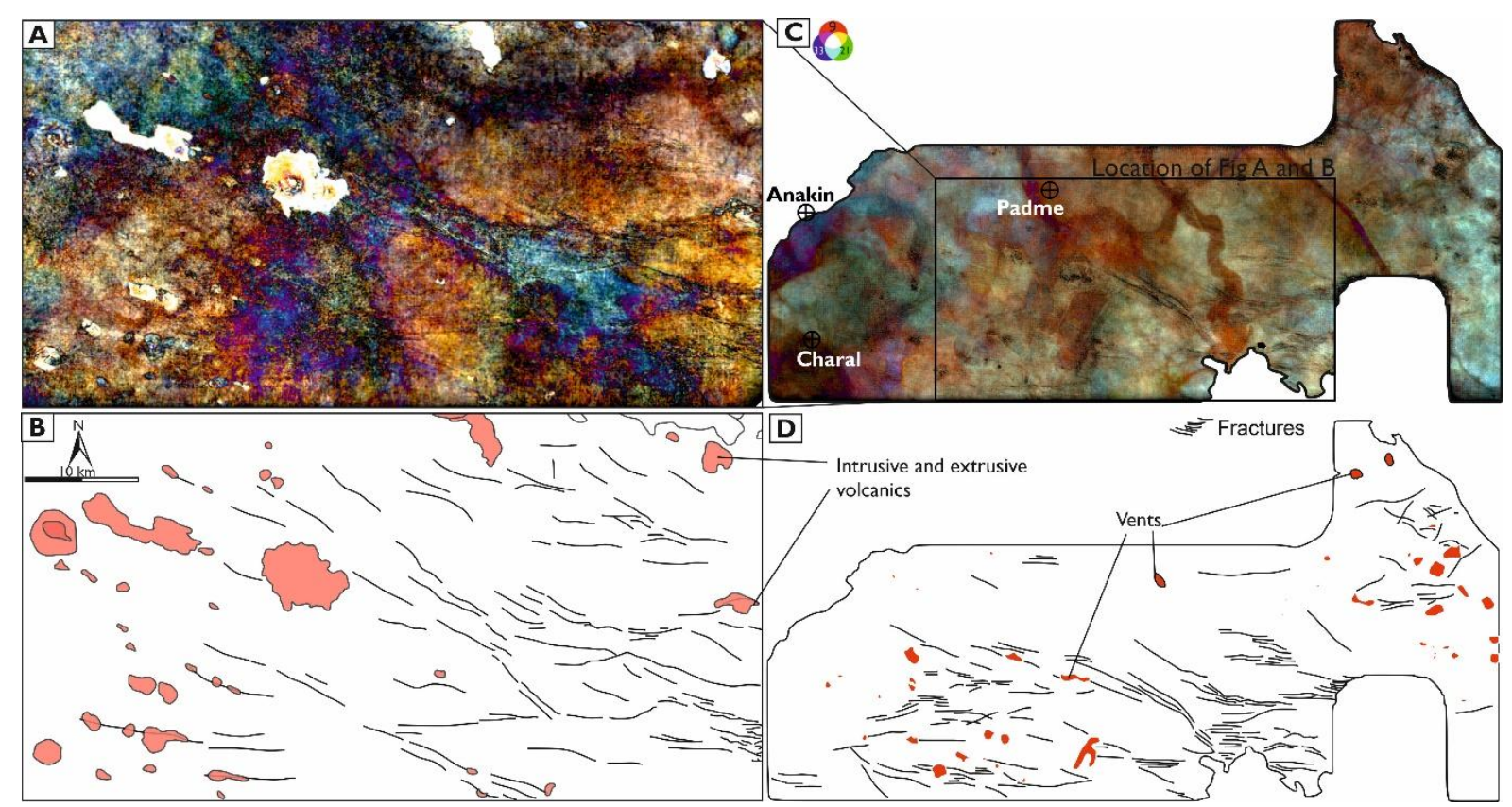

Figure 19: Mapping of faults within the Nappamerri trough. A Spectral decomposition of the Top Volcanics horizon from the Winnie 3D survey. B Interpretation of A with faults and the location of volcanics highlighted. C Spectral decomposition of the Top Toolachee horizon. D Interpretation of discontinuities within the Toolachee Horizon and the location of volcanics highlighted. 

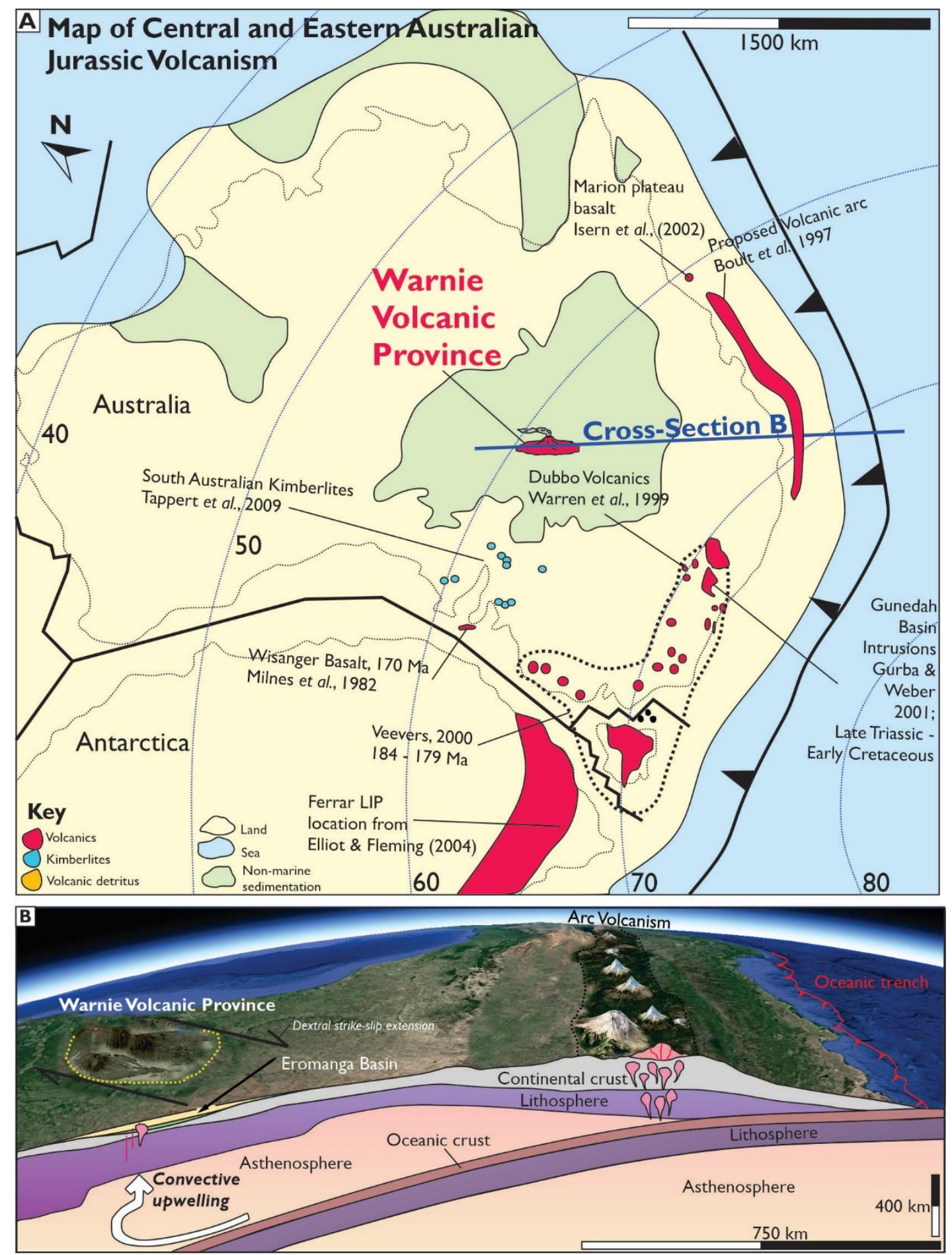

Figure 21: A Palaeogeographic map of Australia in the middle Jurassic (Oxfordian, $160 \mathrm{Ma}$ ), superimposed with the location of middle to late Jurassic volcanics in eastern Australia, described in the text. B Oblique view of Australia, highlighting the subducting pacific slab and associated convective upwelling. Steps in lithospheric thickness have adapted from Fishwick et al., (2008). 